Universidade de Brasília

Faculdade UnB Planaltina

Programa de Pós Graduação em Meio Ambiente e Desenvolvimento Rural

WLLYANE SILVA FIGUEIREDO

ESTRATÉGIAS METALOPROTEÔMICAS NA INVESTIGAÇÃO DE BIOMARCADORES DE MERCÚRIO EM AMOSTRAS DE TECIDO MUSCULAR DE TUCUNARÉS

BRASÍLIA

2015 
UNIVERSIDADE DE BRASÍLIA

FACULDADE UNB PLANALTINA

PROGRAMA DE PÓS GRADUAÇÃO EM MEIO AMBIENTE E DESENVOLVIMENTO RURAL

WLLYANE SILVA FIGUEIREDO

ESTRATÉGIAS METALOPROTEÔMICAS NA INVESTIGAÇÃO DE BIOMARCADORES DE MERCÚRIO EM AMOSTRAS DE TECIDO MUSCULAR

DE TUCUNARÉS

Dissertação apresentada como requisito parcial para obtenção do Título de Mestre em Meio Ambiente e Desenvolvimento Rural pelo Programa de Pós-Graduação em Meio Ambiente e Desenvolvimento Rural da Universidade de Brasília.

Linha de Pesquisa: Monitoramento Ambiental e Saúde.

Orientador: Prof. Dr. Luiz Fabrício Zara

BRASÍLIA 
Ficha catalográfica elaborada automaticamente, com os dados fornecidos pelo(a) autor(a)

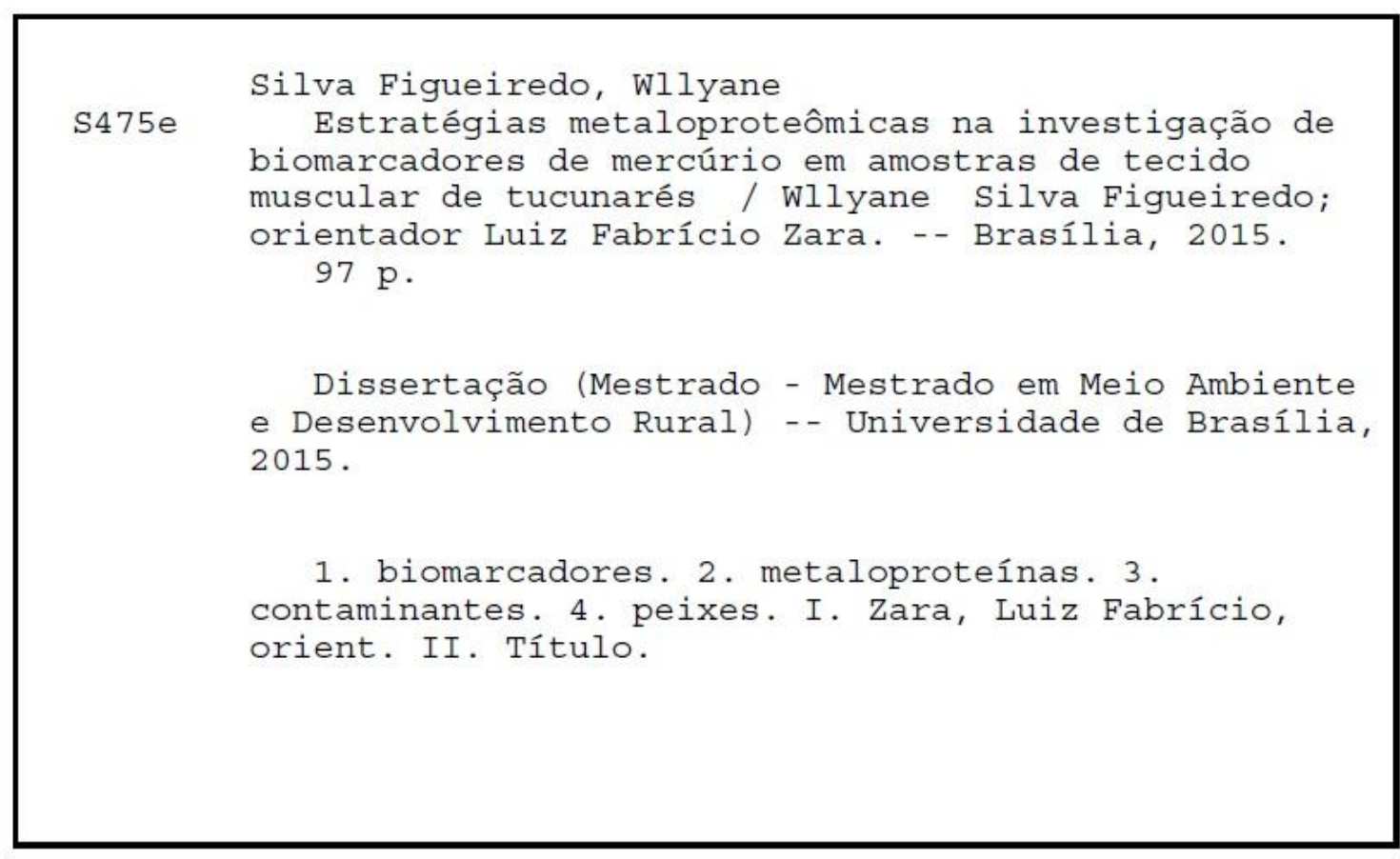




\section{ESTRATÉGIAS METALOPROTEÔMICAS NA INVESTIGAÇÃO DE BIOMARCADORES DE MERCÚRIO EM AMOSTRAS DE TECIDO MUSCULAR DE TUCUNARÉS}

Dissertação apresentada como requisito parcial para obtenção do Título de Mestre em Meio Ambiente e Desenvolvimento Rural pelo Programa de Pós-Graduação em Meio Ambiente e Desenvolvimento Rural da Universidade de Brasília.

Aprovado em 23 de Março de 2015.

BANCA EXAMINADORA

Professor Doutor Luiz Fabrício Zara - Presidente da Banca

Universidade de Brasília

Professor Doutor Eduardo Cyrino Oliveira Filho- Membro Efetivo,

Externo ao Programa

Embrapa Cerrados (EMBRAPA)

Professor Doutor José Vicente Elias Bernardi - Membro Efetivo

Universidade de Brasília 


\section{AUXíLIOS FINANCEIROS}

Projeto regulamentado pela Agência Nacional de Energia Elétrica - ANEEL e desenvolvido no âmbito do Programa de Pesquisa e Desenvolvimento da Energia Sustentável do Brasil S.A.

P\&D: 6631-0001/2012

Contrato Jirau 004/13
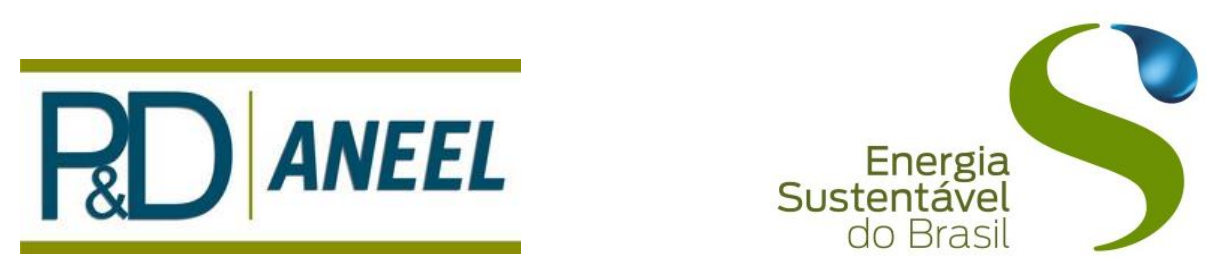
Dedico este trabalho

À minha amada família e amigos, pela contribuição diária e pelo apoio incondicional.

Em especial ao meu pequenino sobrinho, Raphael Henrique, que trouxe luz e alegria para minha vida. Que este trabalho sirva de inspiração a ele daqui uns bons anos. Aos meus orientadores e a todos aqueles que me ajudaram de alguma forma a concluir esta etapa da minha vida. 


\section{AGRADECIMENTOS}

Agradeço a Deus por me dar saúde e coragem para alcançar meus objetivos e por me guiar sempre às boas oportunidades.

À minha família pelo carinho e apoio em todos os momentos da minha vida.

Aos meus amigos por toda palavra de alegria, conforto e incentivo.

Ao meu orientador, Prof. Dr. Luiz Fabrício Zara e aos outros orientadores Prof. Dr. Pedro de Magalhães Padilha e Prof. Dr. Wilson de Figueiredo Jardim por terem me permitido desfrutar um pouco dos seus conhecimentos e por terem dedicado tempo em me corrigir, tirar minhas dúvidas e ouvir meus desabafos.

Ao grupo do Laboratório de Bioanalítica e Eletroforese do Instituto de Biociências da UNESP, pela ótima recepção e grande ajuda nas análises, em especial ao José Cavalcante, à Bruna Cavecci e à Alis Bittarello.

À Fernanda Capuzo da Naturae Consultoria Ambiental, ao Prof. Dr. Ézio Sargentini Júnior do INPA, ao Prof. Dr. Ademir dos Santos da UNESP e ao Prof. Dr. Wilson de Figueiredo Jardim da UNICAMP pelo auxilio nas coletas das amostras.

À Venturo Análises Ambientais, em especial à gerente técnica Vanessa Pezza Franzini, por me encaixar em sua lotada agenda de análises.

Aos meus colegas da Venturo Consultoria Ambiental pelos exemplos de vida e pela torcida.

Ao programa de P\&D da Energia Sustentável do Brasil (ANEEL/PD-6631-0001/2012).

E a todos aqueles que ajudaram direta e indiretamente na execução deste estudo. 
"Na vida, não vale tanto o que temos. Nem tanto importa o que somos. Vale o que realizamos com aquilo que possuímos e, acima de tudo, importa o que fazemos de nós."

(Francisco Cândido Xavier) 


\section{SÚMULA CURRICULAR}

\section{$\underline{\text { Dados pessoais }}$}

Nome: Wllyane Silva Figueiredo

Data de nascimento: 03 de outubro de 1990

E-mail: wllyane@gmail.com

\section{Formação acadêmica}

2008 - 2012 Graduação em Gestão Ambiental.

Universidade de Brasília, UnB, Brasil

\section{Producão científica}

\section{Artigos}

1. VIEIRA, J. C. S.; CAVECCI, B.; QUEIROZ, J. V.; BRAGA, C. P.; PADILHA, C.; LEITE, A.; FIGUEIREDO, W. S.; BUZALAF, M.; ZARA, L. F.; PADILHA, P. M. Determination of mercury fraction linked to protein of muscle tissue and liver of Tucunaré (Cichla ssp.) from Amazon region-Brazil. Analytical and Bioanalytical Chemistry_Em processo de edição.

2. QUEIROZ, J. V.; VIEIRA, J. C. S.; CAVECCI, B.; BRAGA, C. P.; FIGUEIREDO, W. S.; ZARA, L. F.; PADILHA, P. M. Metaloproteínas ligadas ao mercúrio em spots proteicos de Brachyplatystoma filamentosum e Cichla spp. da região amazônica, fracionadas por eletroforese bidimensional. (Em revisão_avaliação iniciada em dezembro de 2014).

3. FIGUEIREDO, W. S.; NASCIMENTO, C. T. C.. Mapeamento da resistividade elétrica do solo no Aterro Sanitário de Formosa. Revista Brasileira de Geofísica. (Em revisão_avaliação iniciada em novembro de 2012, com alterações realizadas em julho de 2014).

\section{Resumos publicados em anais de congressos}

1. FIGUEIREDO, W. S.; FRANZINI, V. P.; SILVA, T. M.; ZARA, L. F.; JARDIM, W. F.; SANTOS, A.; ROCHA, J. C. Estudo do processo de bioacumulação do mercúrio em tucunarés coletados na bacia dos rios Negro, Madeira e Tocantins. In: $37^{a}$ Reunião Anual da Sociedade Brasileira de Química, 2014, Natal - RN. Anais da $37^{\mathrm{a}}$ Reunião Anual da Sociedade Brasileira de Química, 2014.

2. FIGUEIREDO, W. S.; SILVA, T. M.; ZARA, L. F.; S. JUNIOR, E.; SANTOS, A.; PADILHA, P. M.; FRANZINI, V. P. Estudo quantitativo do mercúrio em tecido muscular de tucunarés. In: VII Encontro Nacional de Química Ambiental, 2014, Brasília - DF. Livro de Resumo do VII Encontro Nacional de Química Ambiental, 2014. 
3. SILVA, T. M.; FIGUEIREDO, W. S.; BITTARELlO, A. C.; CAVECCI, B.; VIEIRA, J. C. S.; ZARA, L. F.; PADILHA, P. M. Determinação de mercúrio total em amostras de leite de lactantes residentes no Alto rio Madeira, Rondônia, Brasil.

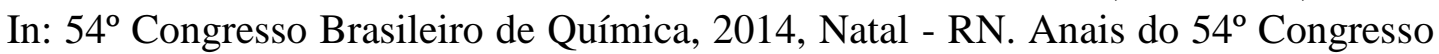
Brasileiro de Química, 2014.

4. SILVA, T. M.; FIGUEIREDO, W. S.; CAVECCI, B.; VIEIRA, J. C. S.; PADILHA, C. C. F.; ZARA, L. F.; PADILHA, P. M. Estudo metaloproteômico quantitativo do mercúrio em amostras de leite de lactantes residentes no alto rio Madeira, Rondônia, Brasil. In: VII Encontro Nacional de Química Ambiental, 2014, Brasília - DF. Livro de Resumo do VII Encontro Nacional de Química Ambiental, 2014.

5. OllVEIRA, C. E. B.; FIGUEIREDO, W. S.; SILVA, T. M.; ZARA, L. F.; ROCHA, J. C. Determinação de elementos traço em matrizes de interesse ambiental coletadas em áreas localizadas na Bacia do alto rio Madeira - RO. In: VII Encontro Nacional de Química Ambiental, 2014, Brasília - DF. Livro de resumos do VII Encontro Nacional de Química Ambiental, 2014.

6. FIGUEIREDO, W. S.; SILVA, T. M.; BERNARDI, J.V.E.; ZARA, L. F.; SANTOS, A.; ROCHA, J. C.; JARDIM, W. F. Monitoramento de mercúrio na ictiofauna na área de influência do Aproveitamento Hidrelétrico Jirau (UHE Jirau), Amazônia, Brasil. In: XVII Congresso Brasileiro de Toxicologia, 2013, Porto Alegre - RS. Anais do XVII Congresso Brasileiro de Toxicologia, 2013.

7. SILVA, T. M.; FIGUEIREDO, W. S.; PASSOS, C. J. S.; ZARA, L. F. Avaliação dos níveis de exposição humana ao mercúrio $(\mathrm{Hg})$ na população da área de influência do Aproveitamento Hidrelétrico de Jirau, Bacia do rio Madeira, Amazônia Ocidental Brasileira. In: XVII Congresso Brasileiro de Toxicologia, 2013, Porto Alegre. Anais do XVII Congresso Brasileiro de Toxicologia, 2013.

8. ZARA, L. F.; PASSOS, C. J. S.; SILVA, T. M.; FIGUEIREDO, W. S.; SERRA, C. V.; SERRA, V. V.; SIMOES, V. L. D.; SANTOS, L. M. Biomonitoring of human mercury $(\mathrm{Hg})$ exposure at the Jirau Hidroelectric Power Plant, Brazilian Amazon. In: XVII EuroAnalysis, 2013, Warsaw. Anais do XVII EuroAnalysis, 2013.

9. SIQUEIRA, A. G.; SILVA, T. M.; FIGUEIREDO, W. S.; ZARA, L. F.; CASTRO, G. R.; BERNARDI, J.V.E. Total mercury $(\mathrm{Hg})$ stock in sediments of the Jirau Hidroelectric Power Plant, Madeira River - Brazilian Amazon. In: XVII EuroAnalysis, 2013, Warsaw. Anais do XVII EuroAnalysis, 2013.

10. FIGUEIREDO, W. S.; SILVA, T. M.; BERNARDI, J.V.E.; ZARA, L. F.; SANTOS, A.; ROCHA, J. C.; JARDIM, W. F. Monitoramento de mercúrio no solo na área de influência do Aproveitamento Hidrelétrico Jirau (AHE Jirau), Amazônia, Brasil In: $5^{\circ}$ Congreso Iberoamericano de Química Analítica e $2^{\circ}$ Congreso Uruguayo de Química Analítica, 2012, Montevideo. Química Analítica Ambiental, 2012. p. $259-259$. 
11. SILVA, T. M.; SERRA, C. V.; SERRA, V. V.; SIMOES, V. L. D.; SANTOS, L. M.; FIGUEIREDO, W. S.; PASSOS, C. J. S.; ZARA, L. F. Biomonitoramento da exposição humana ao mercúrio $(\mathrm{Hg})$ no Aproveitamento Hidrelétrico de Jirau, Amazônia, Brasil. In: $5^{\circ}$ Congreso Iberoamericano de Química Analítica e $2^{\circ}$ Congreso Uruguayo de Química Analítica, 2012, Montevideo. Química Analítica Toxicológica, 2012. p.377 - 377.

12. ZARA, L. F.; BERNARDI, J.V.E.; FIGUEIREDO, W. S.; SILVA, T. M.; ROCHA, J. C.; SANTOS, A.; JARDIM, W. F. Biomonitoramento de Metilmercúrio na área de influência direta do aproveitamento hidrelétrico (AHE) Jirau - Rio Madeira/Amazônia - Brasil. In: IV Congreso Iberoamericano de Química Analítica e X Encuentro Nacional de Química Analítica e Ambiental, 2010, Cancón. Bioindicadores de la contaminación ambiental, 2010, p.75 - 75.

\section{Participação em eventos científicos como ouvinte}

1. I Simpósio em Tecnologia, Inovação e Sustentabilidade Ambiental, 2014, SorocabaSP.

\section{Apresentação oral em eventos científicos}

1. OLIVEIRA, C. E. B., FIGUEIREDO, W. S., SILVA, T. M., ZARA, L. F., ROCHA, J. C. Determinação de elementos traço em matrizes de interesse ambiental coletadas em áreas localizadas na Bacia do alto rio Madeira - RO. In: VII Encontro Nacional de Química Ambiental, 2014, Brasília - DF. 


\section{RESUMO}

FIGUEIREDO, W.S. Estratégias metaloproteômicas na investigação de biomarcadores de mercúrio em amostras de tecido muscular de tucunarés. 2015. 97 p. Dissertação (Mestrado) - Faculdade UnB Planaltina, Universidade de Brasília, Brasília, 2015.

A mensuração de contaminantes no ambiente não traz respostas completas sobre os reais efeitos adversos que estas substâncias podem estar causando aos organismos. A identificação de biomarcadores relacionados ao mapeamento e expressão de metaloproteínas associadas a contaminantes poderão auxiliar na elucidação da dinâmica de vários elementos no ambiente, indicar previamente possíveis riscos de contaminação dos recursos ambientais e ser base para elaboração de mecanismos de neutralização dos seus efeitos. Dessa forma, este estudo buscou a identificação de possíveis biomarcadores de exposição ao mercúrio em tucunarés do rio Negro através de métodos metaloproteômicos. Inicialmente, foram determinadas as concentrações de mercúrio total no tecido muscular de tucunarés capturados em rios e reservatórios hidrelétricos. As concentrações apresentaram pouca variação independente do local de amostragem e algumas estavam superiores aos limites máximos definidos na legislação brasileira. As concentrações aumentaram na sequência: reservatório de Cana Brava < reservatório de Balbina < rio Madeira < rio Purus < reservatório de Tucuruí < rio Apuaú < rio Solimões < rio Negro. As amostras do rio Negro foram selecionadas para definição de um biomarcador proteico através da eletroforese bidimensional (2D-PAGE). O mercúrio foi determinado em 15 possíveis proteínas com massa molar abaixo de 20,1 kDa, sendo 2 mais promissoras à biomarcadoras. Além disso, foi extraído da musculatura dos tucunarés apenas $12,4 \%$ do mercúrio, sendo que $89 \%$ desse mercúrio foi aplicado na técnica 2D-PAGE, resultando em 49,74\% de mercúrio nas proteínas. Essa porcentagem de mercúrio nos spots indica que os procedimentos otimizados de preparação da amostra foram eficientes para ser aplicados na 2D-PAGE. Os resultados metaloproteômicos desse estudo são importantes no subsídio de estudos futuros de identificação e caracterização de biomarcadores de mercúrio em peixes.

Descritores: biomarcadores; metaloproteínas; contaminantes; peixes. 


\begin{abstract}
FIGUEIREDO, W. S. Strategies metalproteomics in research mercury biomarkers in tucunares muscle tissue samples. 2015. 97 p. Dissertation (Master) - Faculty UnB Planaltina, University of Brasilia, Brasilia, 2015.

The measurement of contaminants does not bring complete answers about the real effects that these substances may be causing the organisms. The identification of biomarkers related to mapping and metalloproteins expression associated with contaminants may help to elucidate the dynamics of various elements in the environment indicates previously possible contamination risks of environmental resources and be a basis for development of neutralizing mechanisms of its effects. Thus, this study sought to identify possible mercury exposure biomarkers in tucunares the Negro river through metalproteomics methods. Initially, were determined the total mercury concentrations in muscle tissue of tucunares caught in rivers and hydroelectric reservoirs. They were in a little independent variation of the sampling site and some were above the maximum limits set by Brazilian law. The concentrations increased following: Cana Brava reservoir < Balbina reservoir < Madeira river < Purus river < Tucurui reservoir $<$ Apuau river $<$ Solimões river $<$ Negro river. Samples of the Negro river were selected for definition of a protein biomarker by two-dimensional electrophoresis (2D-PAGE). Mercury was determined in 15 possible protein with molecular weight of $20.1 \mathrm{kDa}$ below, 2 the most promising biomarkers. Moreover, it was extracted from the muscle of tucunarés only $12.4 \%$ of mercury, with $89 \%$ of mercury was applied to the 2D-PAGE technique, and $49.74 \%$ of mercury in proteins. This percentage of mercury in spots indicates that the sample preparation procedures were optimized for efficient be applied to 2D-PAGE. The metalproteomics results of this study are important in the allowance for futures studies of identification and characterization of mercury biomarkers in fish.
\end{abstract}

Descriptors: biomarkers; metalloproteins; contaminants; fish. 


\section{RESUMEN}

FIGUEIREDO, W. S. Estrategias de investigación metaloproteômicas biomarcadores de mercurio en muestras de tejido muscular tucunarés. 2015. 97 p. Tesis (Maestría) Escuela UnB Planaltina, Universidad de Brasilia, Brasilia, 2015.

La medición de los contaminantes no trae respuestas completas sobre los efectos reales que estas sustancias pueden estar causando los organismos. La identificación de biomarcadores relacionados con la cartografía y metalloproteins expresión asociada a contaminantes puede ayudar a dilucidar la dinámica de los diversos elementos en el ambiente indica anteriormente posibles riesgos de contaminación de los recursos ambientales y ser una base para el desarrollo de mecanismos de neutralización de sus efectos. Por lo tanto, este estudio trata de identificar posibles biomarcadores de exposición a mercurio en tucunarés el Río Negro a través metaloproteômicos métodos. Inicialmente, se determinó las concentraciones de mercurio total en el tejido muscular de tucunarés capturados en los ríos y embalses hidroeléctricos. Estaban en una pequeña variación independiente del sitio de muestreo y algunos estaban por encima de los límites máximos establecidos por la legislación brasileña. Las concentraciones aumentaron siguiente: Cana Brava embalses < Balbina embalses < río Madeira < río Purus < Tucuruí embalses < río Apuaú < río Solimões < río Negro. Las muestras del río Negro fueron seleccionados para la definición de un biomarcador de proteínas mediante electroforesis bidimensional (2D-PAGE). Mercurio se determinó en 15 posible proteína con peso molecular de 20,1 kDa abajo, 2 los biomarcadores más prometedores. Por otra parte, se extrajo desde el músculo de tucunarés sólo $12,4 \%$ de mercurio, con $89 \%$ de mercurio se aplicó a la técnica 2D-PAGE, y 49,74\% de mercurio en proteínas. Este porcentaje de mercurio en puntos indica que los procedimientos de preparación de muestras se optimizaron para una eficiente aplicarse a 2D-PAGE. Los metaloproteômicos resultados de este estudio son importantes en la provisión para futuros estudios de identificación y caracterización de biomarcadores de mercurio en el pescado.

Palabras clave: biomarcadores; metalloproteins; contaminantes; los peces. 


\section{LISTA DE FIGURAS}

Figura 1 - Ciclo biogeoquímico do mercúrio .24

Figura 2 - Modelo de biomagnificação do mercúrio. 29

Figura 3 - Comportamento do mercúrio inorgânico e orgânico em peixes capturados no reservatório de Lages. 30

Figura 4 - Principais estruturas que caracterizam o tucunaré. .34

Figura 5 - Níveis de organização estrutural das proteínas. 37

Figura 6 - Mapa de localização das coletas de tucunarés. 42

Figura 7 - Coleta dos dados biométricos do tucunaré açú capturado no rio Negro. 49

Figura 8 - Remoção do músculo branco dorso lateral do tucunaré azul capturado no reservatório da Usina Hidrelétrica Cana Brava. 50

Figura 9 - Variação do comprimento total dos tucunarés coletados nos rios Negro, Apuaú, Solimões, Purus e Madeira, e nos reservatórios das usinas hidrelétricas Balbina, Cana Brava e Tucuruí.

Figura 10 - Variação do peso total dos tucunarés coletados nos rios Negro, Apuaú, Solimões, Purus e Madeira, e nos reservatórios das usinas hidrelétricas Balbina, Cana Brava e Tucuruí. 62

Figura 11 - Variação das concentrações de mercúrio total quantificadas no tecido muscular de tucunarés coletados nos rios Negro, Apuaú, Solimões, Purus e Madeira, e nos reservatórios das usinas hidrelétricas Balbina, Cana Brava e Tucuruí .64

Figura 12 - Variação da massa de mercúrio total em função dos locais de amostragem (rios Negro, Apuaú, Solimões, Purus e Madeira, e reservatórios das usinas hidrelétricas Balbina, Cana Brava e Tucuruí)... .65 Figura 13 - Gel a 15\% obtido por 2D-PAGE, utilizando proteínas fracionadas de tecido muscular de tucunarés oriundo do rio Negro. Os círculos vermelhos indicam possíveis proteínas. .68 


\section{LISTA DE TABELAS}

Tabela 1 - Intervalos de concentrações de mercúrio total em amostras de músculos de peixes predadores e não predadores oriundos de bacias hidrográficas e reservatórios artificiais, de acordo com a literatura.

Tabela 2 - Lista de subespécies de tucunarés, autores e anos e locais onde as subespécies são comumente encontradas. .35

Tabela 3 - Local da coleta, subespécie, número de espécimes, método de captura e data da amostragem dos tucunarés oriundos dos rios Negro, Apuaú, Solimões, Purus e Madeira, e reservatórios das usinas hidrelétricas Balbina, Cana Brava e Tucuruí.

Tabela 4 - Listagem dos equipamentos e acessórios utilizados durante as análises laboratoriais, bem como as marcas, os modelos e os locais de origem

Tabela 5 - Reagentes e soluções utilizados nas análises deste estudo, bem como suas fórmulas químicas, massas molares, fabricantes e locais de origem .51

Tabela 6 - Condições para construção da curva analítica .52

Tabela 7 - Programação da focalização isoelétrica (IEF) .54

Tabela 8 - Programação da corrida eletroforética em segunda dimensão. 55

Tabela 9 - Comprimento, peso e concentrações de mercúrio totais em amostras de várias subespécies de tucunarés capturados nos rios Negro, Apuaú, Solimões, Purus e Madeira, e reservatórios das usinas hidrelétricas Balbina, Cana Brava e Tucuruí.

Tabela 10 - Correlação de Spearman com as variáveis comprimento e concentração de mercúrio total dos tucunarés de todos os locais de amostragem e de classes (águas escuras, águas claras e reservatórios).

Tabela 11 - Concentração de mercúrio total por GFAAS, pI, massa molar e massa de proteína dos 15 spots proteicos das amostras de tecido muscular de tucunarés coletados no rio Negro

Tabela 12 - Número de átomos de mercúrio por molécula de spot proteico das amostras de tecido muscular de tucunarés (Cichla temensis) coletados no rio Negro. 


\section{LISTA DE ABREVIATURAS, SIGLAS E SÍMBOLOS}

2D-PAGE Eletroforese bidimensional em gel de poliacrilamida

ANEEL Agência Nacional de Energia Elétrica

CHAPS 3-[(3-colaminopropil)-dimetilamônio]-1-propano sulfonato)

$\mathrm{CH}_{3} \mathrm{Hg}^{+} \quad$ Metilmercúrio

$\left(\mathrm{CH}_{3}\right)_{2} \mathrm{Hg} \quad$ Dimetilmercúrio

$\mathrm{cm} \quad$ Centímetros

CVAAS Espectrometria de absorção atômica acoplado a sistema de geração de vapor frio de mercúrio

DTT 1,4-ditiotreitol

ESI MS MS Espectrometria de massas em sequência com ionização por eletrospray

g

Gramas

GFAAS

Espectrometria de absorção atômica em forno de grafite

$\mathrm{Hg}$

Mercúrio

$\mathrm{Hg}^{0}$

Mercúrio metálico ou elementar

$\mathrm{Hg}^{+2}$

Mercúrio iônico ou mercúrico

$\mathrm{Hg}_{2}{ }^{2+}$

Íon mercuroso

$\mathrm{HgCl}_{2}$

Cloreto de mercúrio

$\mathrm{Hg}(\mathrm{OH})_{2} \quad$ Hidroxido de mercúrio

$\mathrm{HgT}$

Mercúrio total

IBGE

Instituto Brasileiro de Geografia e Estatística

IEF

Isoeletrofocalização

$\mathrm{kDa}$

QuiloDalton (1 Da = 1,661 x 10-24g)

$\mathrm{kg}$

Quilograma

$\mathrm{km}$

Quilômetro

L

Litro

$\mathrm{m}$

Metro

$\mathrm{mA}$

Microamperagem

$\min$

Minuto

mg

Miligrama

$\mathrm{mm}$

Milímetros 


\begin{tabular}{ll} 
MM & Massa molar \\
MW & Megawatts \\
OMg & Nanograma \\
$\mathrm{p}$ & Organização Mundial de Saúde \\
$\mathrm{pI}$ & Grau de significância nos testes estatísticos \\
$\mathrm{r}$ & Ponto isoelétrico da proteína \\
rpm & Grau de correlação entre variáveis \\
SAD 69 & Rotações por minuto \\
SDS & South American Datum 1969 \\
SDS-PAGE & Dodecil-sulfato de sódio \\
SISBIO & Eletroforese em gel de poliacrilamida em uma dimensão \\
spot & Sistema de Autorização e Informação em Biodiversidade \\
TEMED & Ponto 2D de proteínas \\
Tris-HCl & N,N`,N,N`-tetrametiletilenodiamina \\
UHE & Tris (hidroximetil) aminometano ácido \\
$\mu$ L & Usina Hidrelétrica \\
$\mu$ S.cm & Microlitro \\
UTM & Medida da condutividade elétrica \\
v & Universal Transversa de Mercator \\
W & Voltagem \\
& Corrente elétrica \\
\hline &
\end{tabular}




\section{SUMÁRIO}

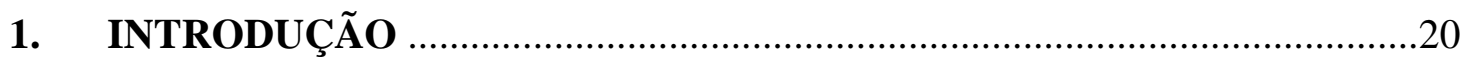

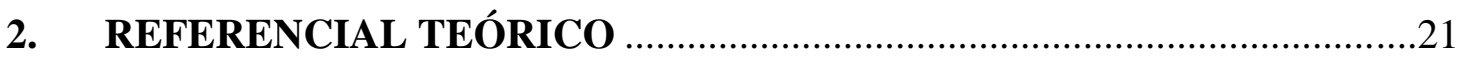

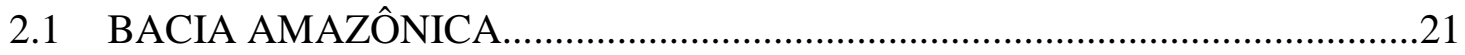

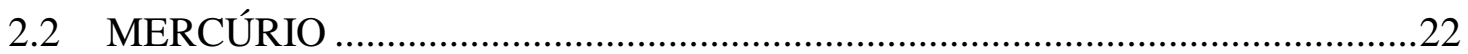

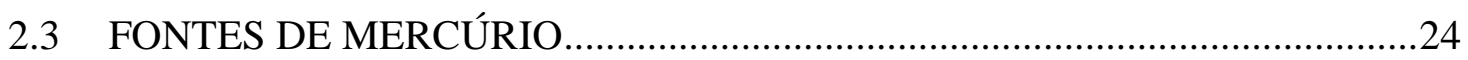

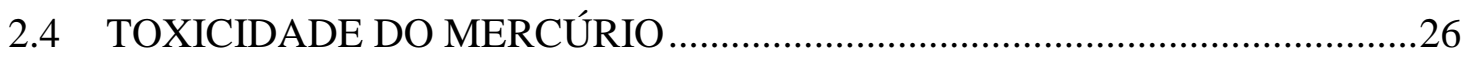

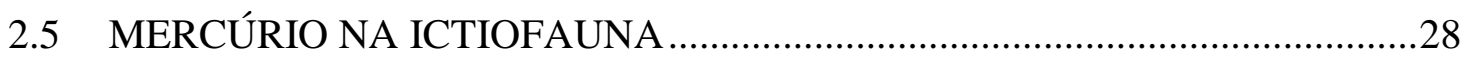

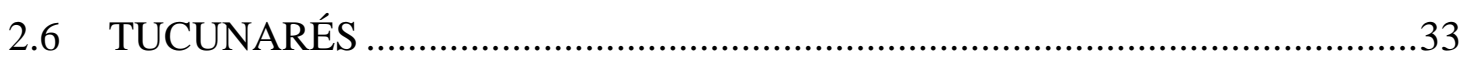

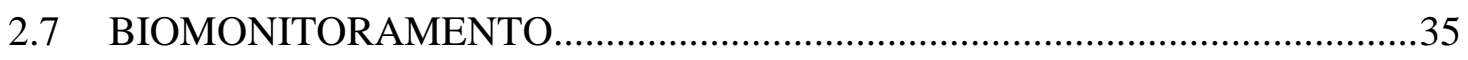

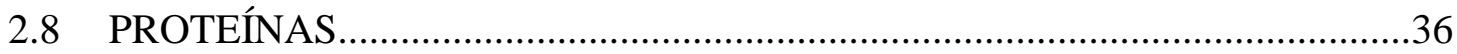

2.9 METALÔMICA E TÉCNICAS DE FRACIONAMENTO_...................................38

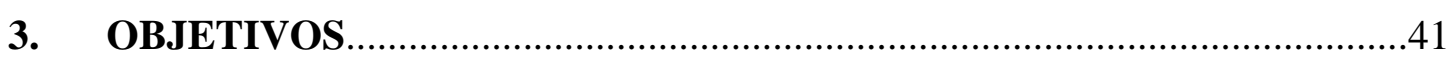

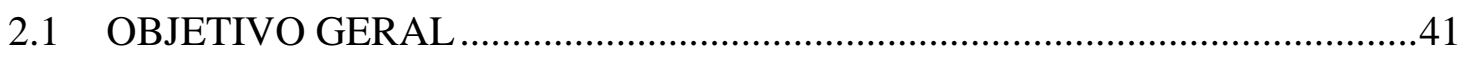

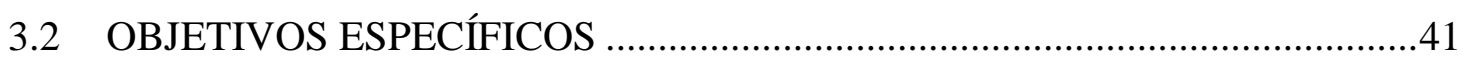

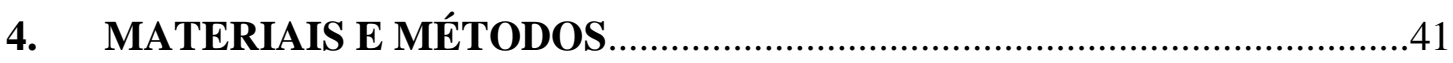

4.1 CARACTERIZAÇÃO DAS ÁREAS DE ESTUDO ……………………….....41

4.1.1 Rio Negro

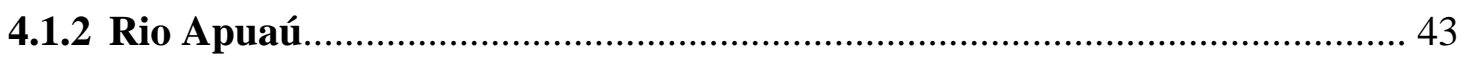

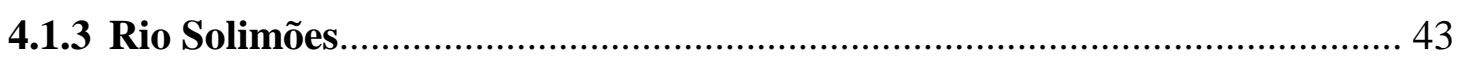

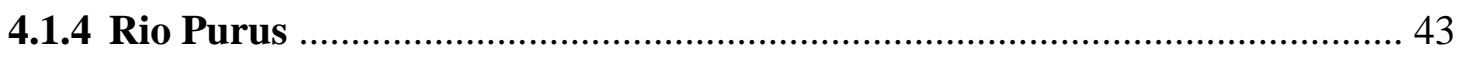

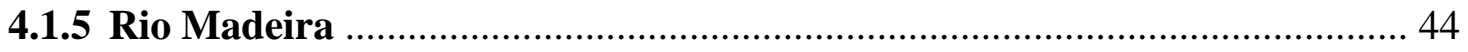

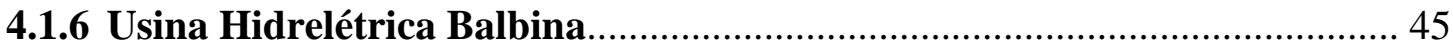

4.1.7 Usina Hidrelétrica Cana Brava................................................................ 45

4.1.8 Usina Hidrelétrica Tucuruí .............................................................................. 46

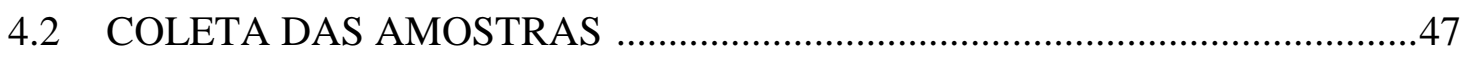

4.3 EQUIPAMENTOS E ACESSÓRIOS ………………….................................50

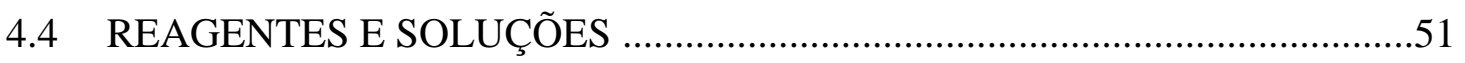

4.5 QUANTIFICAÇÃO DE MERCÚRIO TOTAL NOS TECIDOS .........................52

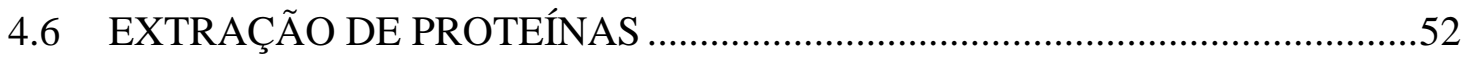

4.7 QUANTIFICAÇÃO DE PROTEÍNAS TOTAIS...............................................53

4.8 PRIMEIRA ETAPA DO PROCESSO ELETROFORÉTICO ..............................53 
4.9 SEGUNDA ETAPA DO PROCESSO ELETROFORÉTICO …........................54

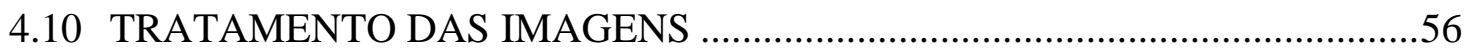

4.11 QUANTIFICAÇÃO DO MERCÚRIO TOTAL NOS TECIDOS, PRECIPITADOS E SPOTS PROTEICOS .....................................................56

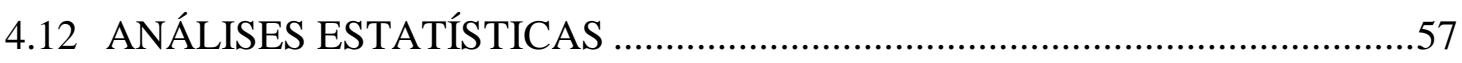

4.13 LICENÇA DE COLETA E TRANSPORTE DE AMOSTRAS

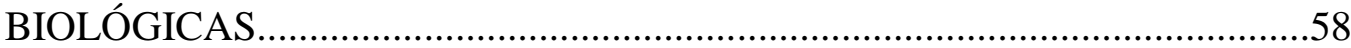

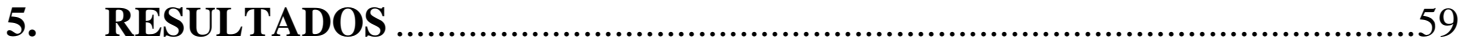

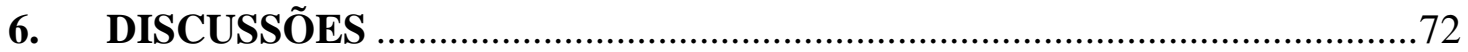

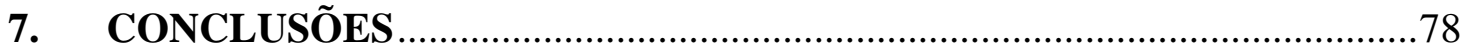

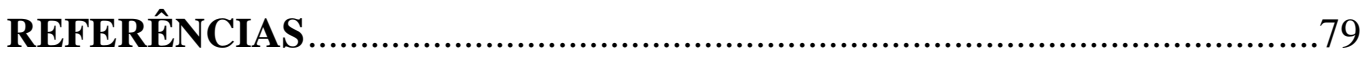

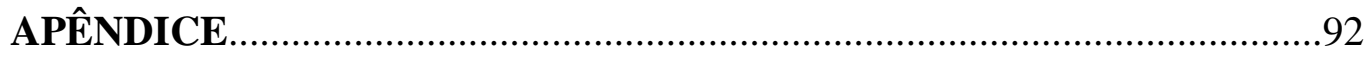

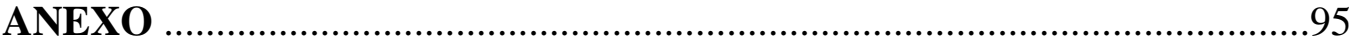




\section{INTRODUÇÃO}

O mercúrio é um elemento ubíquo, de comportamento acumulativo e potencialmente tóxico quando ingerido em grandes concentrações, podendo causar danos permanentes ou levar ao óbito (BORRELL et al., 2014). Por essa razão, tem despertado nos últimos anos o interesse em estudar seu ciclo e avaliar os riscos deste elemento aos ecossistemas (MALM, 1998).

Atualmente, as atividades humanas emitem cerca de 2.000 toneladas métricas ao ano de mercúrio (KRABBENHOFT \& SUNDERLAND, 2013). Entretanto, o maior aporte de mercúrio no ambiente é proveniente de fontes naturais (ROULET et al., 1998, 1999; FADINI \& JARDIM, 2001). O mercúrio disponibilizado em sua forma orgânica, seja de origem natural ou antropogênica (garimpos, reservatórios artificiais, desmatamento, entre outros), está comprometendo os recursos haliêuticos, os quais constituem uma das principais fontes de proteína animal para as comunidades que vivem ao longo dos rios e reservatórios brasileiros e que geram mais de 200.000 empregos diretos (BARTHEM \& FABRÉ, 2004; PASSOS et al., 2003; ROULET et al., 1998, 1999). Diversos estudos apontam significativas concentrações de mercúrio em peixes (BASTOS, 2004; BASTOS et al., 2006; BARBOSA et al., 2003; CASTILHOS \& BIDONE, 2000; KASPER et al., 2012; MALM et al., 1995a; URYU et al., 2001).

Considerando os potenciais efeitos tóxicos do mercúrio em ecossistemas aquáticos e, consequentemente, na saúde do ser humano, há uma crescente preocupação com a bioquímica dos processos envolvidos na sua acumulação (BARGHIGIANI et al., 1989). A metalômica apresenta-se como uma proposta inovadora para o desenvolvimento de biomarcadores da toxidade do mercúrio associados às metaloproteínas, contribuindo na elucidação dos aspectos fisiológicos e funcionais responsáveis pelo transporte de mercúrio na biota (NEVES et al., 2012).

Dessa forma, este estudo objetiva a determinação das concentrações de mercúrio total em tecido muscular de tucunarés (Cichla sp.) oriundos de alguns rios amazônicos e reservatórios de usinas hidrelétricas. Além da identificação de possíveis biomarcadores de exposição ao mercúrio em tucunarés naturais do rio Negro. 


\section{REFERENCIAL TEÓRICO}

\subsection{BACIA AMAZÔNICA}

A bacia amazônica foi formada a partir da Era Cenozóica e possui aproximadamente $2.10^{6} \mathrm{~km}^{2}$. O relevo é predominantemente plano, a maior parte do território tem altitude inferior a 200 metros. O clima, em geral, é quente, com temperatura média anual de $26,6^{\circ} \mathrm{C}$. Embora as massas de ar sejam secas, é uma região muito úmida devido à alta taxa de evapotranspiração. A umidade relativa média é de $76 \%$ no período de estiagem e de $87 \%$ no período chuvoso (BARTHEM \& FABRÉ, 2004).

Os níveis dos rios da Amazônia apresentam um ciclo unimodal anual, com um período de águas baixas e outro de águas altas, o qual ocorre de outubro a abril e pode ter o nível da água elevado de 8 a 15 m (DÓREA, 2003). Devido a essa regularidade a vegetação é adaptada, sendo composta por gramíneas e vegetações de pequeno porte em áreas mais baixas e por vegetação arbórea em áreas mais altas. As áreas alagadas formam ambientes hipoxêmicos ou anóxicos e com $\mathrm{pH}$ baixo, devido à intensa decomposição da matéria orgânica que consome o oxigênio dissolvido na água e libera o gás sulfídrico. Estas condições limnológicas podem aumentar a metilação do mercúrio na água, e consequentemente a contaminação dos peixes (BARTHEM \& FABRÉ, 2004).

A erosão dos vales das Cordilheiras dos Andes provocada pelas chuvas que chegam a $8.000 \mathrm{~mm} /$ ano é a principal responsável pelo carreamento de nutrientes e sedimentos para os ecossistemas aquáticos brasileiros (BARTHEM \& FABRÉ, 2004).

Alguns mananciais da bacia amazônica possuem águas mais ácidas ( $\mathrm{pH}$ próximo a 4), com uma coloração escura devido, sobretudo, à quantidade de substâncias húmicas dissolvidas e ácidos orgânicos, provenientes da decomposição da rica camada vegetal denominada "liteira". Outros rios e lagos são classificados como águas brancas, devido ao conteúdo de sedimentos, sendo seu pH próximo a 7 (SANTOS et al., 2005; DA SILVA et al., 2006). Já as águas claras são originárias da Amazônia Central, onde o relevo é mais regular, e por isso há uma menor taxa de erosão. São águas límpidas, com pH variado entre 4,5 e 7,0 e apresentam características químicas de transição entre as águas pretas e brancas. O encontro dessas distintas classes de rios confere à bacia amazônica características físico-químicas bem peculiares, destacando-se quanto às 
concentrações de elementos traço, como o manganês e o mercúrio (BARBOSA et al., 2003; QUEIROZ et al., 2009).

A classificação dos rios amazônicos em águas brancas, pretas e claras foi proposta há mais de 20 anos por Harold Sioli, e posteriormente foi validada com estudos limnológicos realizados por Junk (1983), Ayres (1995) e Fabré et al. (2000).

Quanto às comunidades que habitam a bacia amazônica são em grande parte constituídas por pequenos produtores rurais e ribeirinhos, sendo suas atividades de subsistência baseadas no extrativismo vegetal, na pecuária e na pesca. Contudo, há uma crescente migração para os centros urbanos devido, sobretudo, à ocupação do solo pela pecuária extensiva e construção de grandes empreendimentos hidrelétricos (QUEIROZ et al., 2012). Além disso, essas duas atividades também contribuem com o aporte do mercúrio no ambiente (KEHRIG et al., 2009).

\subsection{MERCÚRIO}

O mercúrio é um metal líquido encontrado no ambiente associado a outros elementos como o enxofre. Essa ligação forma o minério cinabre $(\mathrm{HgS})$, o qual apresenta uma coloração vermelha ou preta, sendo as maiores reservas na Espanha e na Itália (MICARONI et al., 2000).

Além disso, o mercúrio metálico $\left(\mathrm{Hg}^{0}\right)$ possui a propriedade de formar amálgama, tornando possível a extração do ouro disperso nos solos e sedimentos. Após a queima do amálgama, o mercúrio é lançado no ambiente em forma de vapor e, quando há perdas no manuseio, também na forma líquida (BASTOS et al., 2004; BOISCHIO \& BARBOSA, 1993).

Registros mostram que a exploração do mercúrio na Espanha ocorreu há dois mil anos e na China o uso do cinabre como pigmento ocorreu há três mil anos (MICARONI et al., 2000). O uso de mercúrio na indústria de mineração para amalgamar metais preciosos também é remoto, desde 2700 a.C. as civilizações fenícia e púnica já comercializavam mercúrio proveniente de minas de Almadén, na Espanha. O romano Caio Plínio Segundo, em sua obra História Natural, descreveu a técnica de mineração de ouro e prata com um processo de fusão. No entanto, essa tecnologia somente foi usada na prática pelos romanos por volta de 50 d.C. e é semelhante aos procedimentos utilizados atualmente na Ásia, África e em vários países da América do Sul (LACERDA, 1997). 
Estima-se que, mundialmente entre os anos 1550 e 1800, as emissões antropogênicas de mercúrio para o ambiente foram de 200.000 toneladas, somente o Brasil teria liberado, nesse mesmo período, cerca de 400 toneladas, sendo sua maioria proveniente de garimpos ilegais (LACERDA, 1997; MALM, 1998). Durante a corrida do ouro, estima-se que no Brasil havia 1,6 milhões pessoas trabalhando com garimpo (MALM, 1998).

Entretanto, a fonte desse mercúrio encontrado em solos amazônicos é questionável. Roulet et al. $(1998,1999)$ sugeriram que a maior contribuição do aporte do mercúrio é de origem natural. Posteriormente, Fadini \& Jardim (2001), fizeram uma investigação quantitativa de mercúrio em água, atmosfera e solos numa região onde pouca atividade garimpeira foi documentada e concluíram que há grande possibilidade de existir uma reserva natural desse elemento em solos amazônicos que justifiquem as altas concentrações encontradas nos compartimentos abióticos e bióticos massivamente estudados.

O mercúrio, quando encontrado em grandes concentrações, é extremamente tóxico para os seres vivos e é potencialmente poluidor para os ecossistemas. Um dos maiores desastres ambientais que expôs risco eminente ao ambiente ocorreu em 1953 na Baía de Minamata, sudoeste do Japão (MICARONI et al., 2000). De acordo com Honda et al. (2006) e Griesbauer (2007), uma companhia local de produção de petróleo e plásticos, que utilizava mercúrio como catalizador na produção de acetaldeído, depositou na Baía de Minamata 27 toneladas de metilmercúrio ao longo de 37 anos. Foram contabilizadas mais de 900 mortes e cerca de 3.000 pessoas foram diagnosticadas com sintomas da contaminação por metilmercúrio, a denominada "Doença de Minamata".

No Iraque, entre 1972 e 1973, em uma cultura de trigo, o metilmercúrio contaminou cerca de 6.000 pessoas, destas, 400 vieram a óbito e o restante desenvolveu sintomas característicos da "Doença de Minamata" (HONDA et al., 2006).

Além da "Doença de Minamata", outra terminologia é usada para os sintomas de exposição ao mercúrio, a denominada "Síndrome do Chapeleiro Maluco". Na Inglaterra, em meados do século XIX, os chapéus eram produzidos com vapor de mercúrio metálico a fim de atender aos requisitos de elegância. Com anos de exposição, os chapeleiros desenvolviam uma forma clínica de hidrargirismo, característico por graves problemas de coordenação motora (VROOM \& GREER, 1972). 


\subsection{FONTES DE MERCÚRIO}

O mercúrio pode ser encontrado nos vários compartimentos ambientais (ar, água, sedimento, solo e biota) na forma inorgânica como $\mathrm{Hg}$ elementar $\left(\mathrm{Hg}^{0}\right)$, íon mercuroso $\left(\mathrm{Hg}_{2}{ }^{2+}\right)$ e íon mercúrico $\left(\mathrm{Hg}^{2+}\right)$; e na forma orgânica como íon mercúrico, o qual se associa com ligantes orgânicos naturais ou covalentemente a um radical orgânico, formando o metilmercúrio $\left(\mathrm{CH}_{3} \mathrm{Hg}^{+}\right)$e o dimetilmercúrio $\left(\left(\mathrm{CH}_{3}\right)_{2} \mathrm{Hg}\right)$ (HONDA et al., 2006; MICARONI et al., 2000).

$\mathrm{Na}$ atmosfera, ${\mathrm{o} \mathrm{Hg}^{0}}^{0}$ sofre processos oxidativos e é transformado para a forma divalente $\left(\mathrm{Hg}^{2+}\right)$, este pode ser encontrado como os compostos $\mathrm{HgCl}_{2}$ e $\mathrm{Hg}(\mathrm{OH})_{2}$, usualmente conhecidos como mercúrio gasoso reativo. Essas duas formas de mercúrio depositam-se nos vários compartimentos ambientais através das precipitações. Uma vez depositado nos rios, uma porção é complexada enzimaticamente por microorganismos a radicais metílicos, convertendo-se em metilmercúrio, o qual posteriormente acumula nos organismos aquáticos. A outra porção é reemitida para a atmosfera quando é convertida para sua forma inicial $\left(\mathrm{Hg}^{0}\right)$ por meio de oxirredução e reações biológicas, conforme ilustrado na Figura 1 (DA SILVA et al., 2006; GRIESBAUER, 2007; KRABBENHOFT \& SUNDERLAND, 2013; PADOVANI et al., 1995).

Figura 1 - Ciclo biogeoquímico do mercúrio.

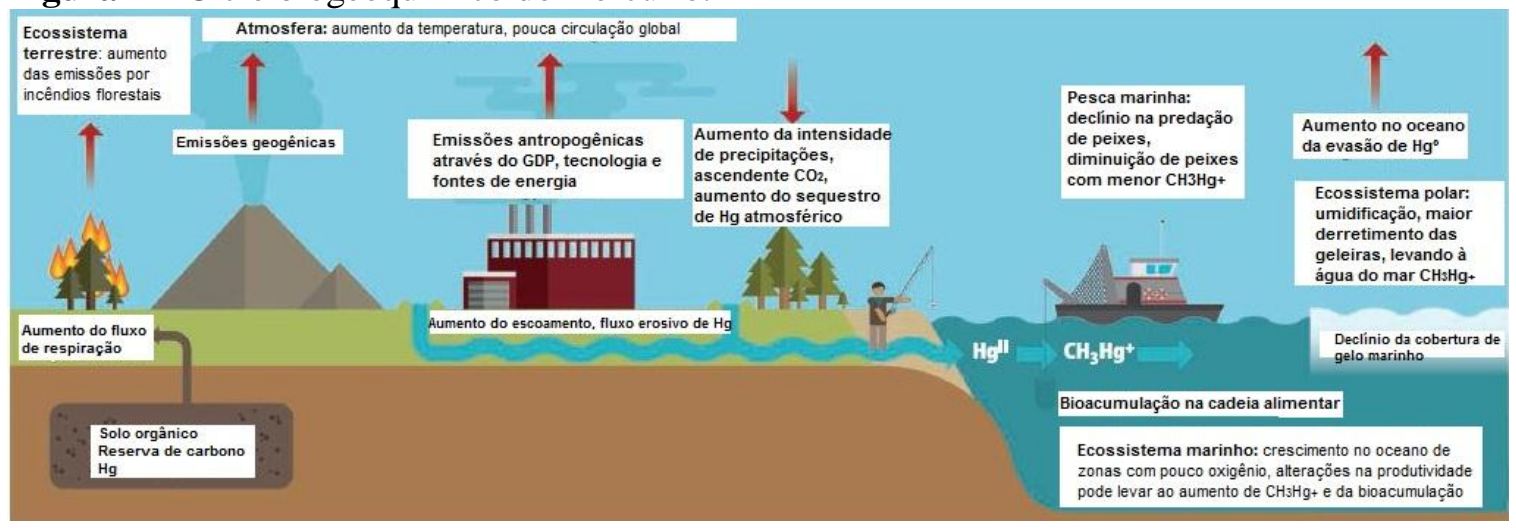

Fonte - Krabbenhoft \& Sunderland (2013)_adaptado.

O ciclo global do mercúrio também é afetado pelo clima. Elevadas temperaturas influenciam a oxidação do mercúrio na atmosfera e o aumento da intensidade e incidência de precipitações que podem conduzir a um aumento acentuado de mercúrio nos sistemas aquáticos e terrestres, por meio de deposição direta, escoamento e erosão (Figura 1) (KRABBENHOFT \& SUNDERLAND, 2013).

A principal fonte natural de mercúrio é o manto e a crosta da Terra, onde o mercúrio é liberado para a atmosfera por meio de vulcões, falhas e outros processos de 
desgaseificação do interior do planeta (Figura 1). Além disso, boa parte do mercúrio é proveniente de fontes secundárias difusas em oceanos e continentes (minas). Cerca de 95\% do mercúrio encontra-se depositado em solos, apenas 3\% nas águas oceânicas e mananciais, e 2\% na atmosfera (BORRELL et al., 2014; MICARONI et al., 2000; ROULET et al., 1998). Os solos amazônicos são anualmente inundados, o que favorece a disponibilidade de mercúrio para o ecossistema aquático (BASTOS et. al.,2007).

A liberação e metilação potencial do mercúrio nos ecossistemas também estão associadas às atividades humanas complexas, especialmente em produção de vacinas, cloro-soda, acetaldeído, polpa de papel, tintas, lâmpadas de vapor de mercúrio, baterias, mineração de ouro, solos desmatados, aplicação de agrotóxicos na agricultura e silvicultura e queima de biomassa e combustíveis fósseis, conforme apresentado na Figura 1 (GROTTO et al., 2010; LACERDA, 1995, 1997; MICARONI et al., 2000; ROULET et al., 1998; SOUZA et al., 2000).

É importante destacar que a construção de grandes empreendimentos hidrelétricos é um dos vários fatores que influenciam a dinâmica hidrobiogeoquímica natural do mercúrio no ambiente, visto que, a construção de reservatórios artificiais formam microambientes lênticos que podem maximizar o processo de organificação do mercúrio e solubilizar outras substâncias tóxicas (AMORIM et al., 2000; ROULET et al., 1998).

Além dos reservatórios artificiais, numerosos estudos na região amazônica, relatam os impactos do uso do mercúrio em garimpos de ouro (MALM et al., 1995b, 1997). Contudo, a maioria não analisa a influência do clima, as características pedológicas, atual dinâmica biogeoquímica e idade da cobertura dos solos (ROULET et al., 1998).

Roulet et al. (1998, 1999) afirmam que mais de 97\% do mercúrio acumulado na superfície dos solos amazônicos é de origem natural. O desmatamento resultante da colonização intensiva e práticas agrícolas resultam em erosão de solos e lixiviação desse mercúrio natural não somente superficialmente, mas em profundidade até $80 \mathrm{~cm}$.

A acumulação do mercúrio está associada ao húmus no horizonte orgânico dos solos, pois há forte afinidade com a matéria orgânica, argilas e óxidos de alumínio, silício, ferro e manganês. Os níveis de oxi-hidróxido ( $\mathrm{Fe}$ e $\mathrm{Al}$ ) possivelmente controlam as concentrações de mercúrio ao longo dos perfis de profundidade do solo e entre diferentes tipos de solos (ROULET et al., 1998). 
A concentração de metilmercúrio nos compartimentos ambientais abióticos é influenciada por diversos fatores como presença de matéria orgânica, níveis de $\mathrm{pH}$, potencial redução-oxidação, quantidade de oxigênio, atividades microbiológicas, entre outros (MALM, 1998).

Além das bactérias, outros organismos contribuem para a produção de metilmercúrio no solo. Um estudo recente de Rodríguez Álvarez e colaboradores (2014), próximo a uma área de mineração rica em mercúrio localizada em Almadén Espanha, sugere que o metilmercúrio é facilmente bioacumulado por minhocas e que estes organismos também podem contribuir para a produção dessa forma de mercúrio.

\subsection{TOXICIDADE DO MERCÚRIO}

O homem é constituído por $61 \%$ de hidrogênio, $25 \%$ de oxigênio, $10 \%$ de carbono, $2 \%$ de nitrogênio e outros $2 \%$ estão divididos entre minerais e oligoelementos importantes para o perfeito funcionamento das funções biológicas. O cobre, por exemplo, participa da síntese da hemoglobina, em funções neuro-cerebrais, queratinização e pigmentação da pele e do cabelo; o cromo é importante para o metabolismo dos açúcares; o selênio é anti-oxidante importante para o bom funcionamento das funções nervosas e musculares; e o zinco protege o fígado contra danos químicos, regula o crescimento e é importante para o sistema imunológico. Entretanto, mesmos os elementos essenciais, se ingeridos em excesso ou quando se associam a outros elementos, podem causar efeitos deletérios ao homem (CORTECCI, 2003; LEMIRE et al., 2011; STEIGER, 1998).

Além disso, a interação do homem com o ambiente faz com que xenobióticos também estejam presentes em seu organismo. A OMS (1998) classifica alguns metais como potencialmente tóxicos se ingeridos em grandes concentrações ou por longos períodos, dentre eles, o chumbo pode causar problemas irreversíveis ao cérebro, anemia, tumores renais, retardamento do crescimento, hiperatividade e problemas reprodutivos; o cádmio é potencialmente perigoso por causar a calcificação nos rins, deformação óssea, disfunção renal, câncer e doenças cardiovasculares; e o mercúrio, que em sua forma orgânica possui afinidade com os tióis proteicos presentes no cérebro e por essa razão é extremamente nocivo ao sistema nervoso central (DIETZ et al., 2013; GRIESBAUER, 2007; HONDA et al., 2006; ROULET et al., 1998; TAYLOR et al., 2014). 
Dentre os principais efeitos do mercúrio à saúde humana, tem-se falta de coordenação nos movimentos, vertigem, formigamento ou dormência nas extremidades, dores na cabeça, cãibras, fraqueza, depressão, alterações sensoriais, distúrbios visuais e auditivos, dificuldade na articulação das palavras, tosse, inflamações gastrointestinais, quedas de cabelo, náuseas, vômitos, dificuldade respiratória, aumento dos riscos de desenvolvimento de doenças cardiovasculares e, em casos agudos, pode levar ao coma e ao óbito (BASTOS \& LACERDA, 2004; BOISCHIO \& BARBOSA, 1993; DIETZ et al., 2013; JACOB-FERREIRA et al., 2011; MICARONI et al., 2000).

De acordo com Boischio \& Barbosa (1993) e Correa et al. (2014) o mercúrio orgânico penetra com grande facilidade na placenta, podendo causar ao feto: microcefalia, deficiências visuais, auditivas, motoras e mentais. Esses quadros clínicos podem ocorrer mesmo sob pequenas concentrações de mercúrio, devido à fragilidade dos seus organismos. Outra forma de exposição a esse metal em mamíferos é através do aleitamento materno. O leite apesar de ser fonte de proteínas e minerais, é também uma via de excreção de diversas substâncias, inclusive metais pesados (VIEIRA et al., 2013).

O metilmercúrio é a forma mercurial que pode sofrer bioacumulação e causar diversos malefícios. Quando ingerido, é absorvido no trato digestivo, onde forma um complexo com o aminoácido cisteína, o qual facilita a entrada nas células de todo o organismo (BORRELL et al., 2014).

Em contraposto, o mercúrio metálico, quando inalado por humanos, mais de $85 \%$ é rapidamente absorvido pelos pulmões, há migração para corrente sanguínea, a maior parte é oxidada e acumula nos rins até, finalmente, os íons metálicos serem excretados através da urina sem causar efeitos adversos consideráveis (MALM, 1998). Uma pequena porção pode sofrer organificação no organismo e causar algum efeito adverso. De acordo com Honda et al. (2006), apenas concentrações muito altas de vapor de mercúrio podem causar danos à saúde como problemas respiratórios, renais e motores.

O mercúrio é naturalmente eliminado do organismo humano ao longo do tempo, sendo a excreção das formas inorgânicas através da urina e das unhas e, as espécies orgânicas por meio do cabelo. Bactérias presentes no intestino de humanos podem desmetilar o metilmercúrio, resultando em mercúrio inorgânico e carbono, os quais são posteriormente eliminados pelas fezes (GRIESBAUER, 2007). 
Alguns estudos registaram efeitos do mercúrio inorgânico sobre o processo reprodutivo de peixes, mas ainda há pouco conhecimento acerca do risco toxicológico desse elemento sobre a morfologia da biota aquática (RIBEIRO et al., 2008).

É importante ressaltar que alguns mecanismos de proteção toxicológica podem ocorrer, em diversos animais, quando há associação entre mercúrio e proteínas complexas, como as metalotioneínas. Essas proteínas podem ficar retidas em células gastrintestinais, hepáticas e renais, sem causar danos nocivos à saúde (BOISCHIO \& BARBOSA, 1993).

Existe um mecanismo, o qual ocorre no fígado de diversos organismos que, eventualmente transforma o mercúrio orgânico em formas inorgânicas menos tóxicas, tais como seleneto de mercúrio - HgSe (BORRELL et al., 2014; DIETZ et al., 2013; RUELAS-INZUNZA et al., 2013).

Lemire et al. (2011) sugerem o consumo do selênio, oriundo da castanha do Pará, frango, carne de caça, peixe e ovos, para neutralizar a ação do chumbo e do mercúrio. Correa et al. (2014) afirmam que além do selênio tornar o mercúrio menos reativo, ele tem efeito significativo na dispersão do mercúrio em órgãos e influencia em sua excreção.

Entretanto, o selênio em grandes concentrações pode causar sérios distúrbios, pois não complexa todas as espécies de mercúrio e não neutraliza todos os seus efeitos (GANTHER \& SUNDE, 2007). Essa relação entre elementos é muito mais complexa do que uma ligação molecular direta (PASSOS et al., 2003).

\subsection{MERCÚRIO NA ICTIOFAUNA}

A transformação das espécies inorgânicas de mercúrio para a forma orgânica $\mathrm{CH}_{3} \mathrm{Hg}^{+}$ocorre na coluna de água, no sedimento e posteriormente são bioacumuladas por organismos aquáticos (MICARONI et al., 2000). Os primeiros elos da cadeia alimentar aquática a absorverem mercúrio do sedimento são alguns peixes detritívoros e os fitoplânctons, em seguida esses últimos organismos são consumidos pelos zooplânctons, os quais são alimentos para diversas espécies de organismos aquáticos, sobretudo, os peixes. A partir daí, animais dos mais diversos gêneros (aves, répteis e mamíferos) participam da cadeia e, consequentemente, da dispersão do metilmercúrio na biota. Todo esse complexo processo é denominado biomagnificação (Figura 2) (LAMA et al., 2011; GRIESBAUER, 2007). De acordo com Lacerda e Malm (2008), o 
mercúrio é o único metal capaz de sofrer biomagnificação em quase todas as cadeias alimentares.

Figura 2 - Modelo de biomagnificação do mercúrio.

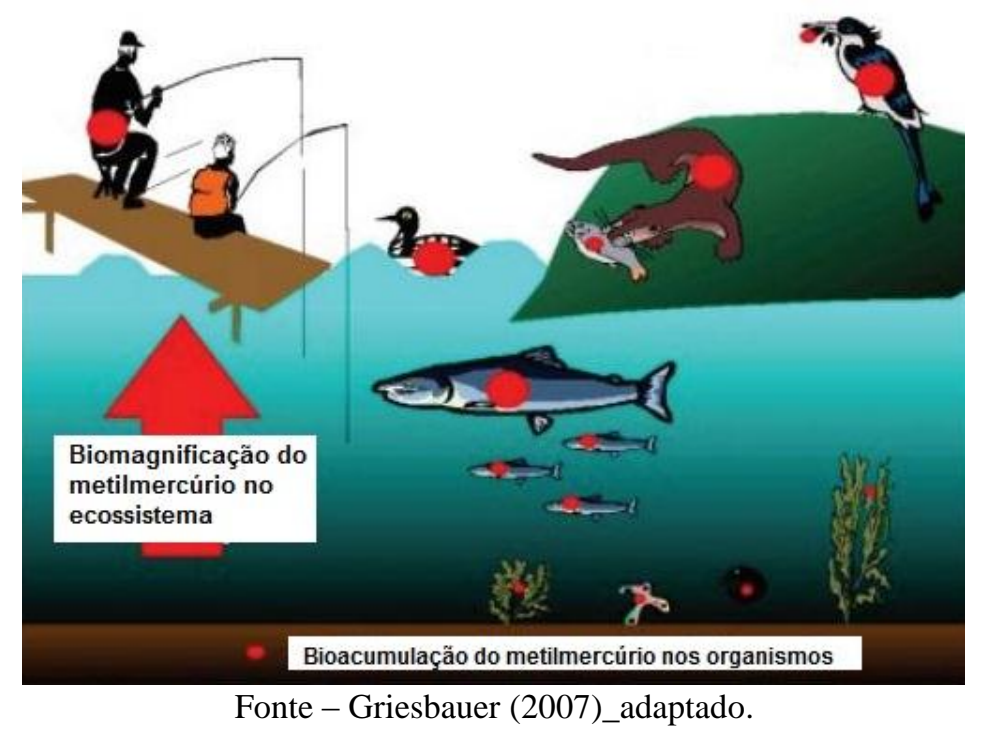

A ingestão de peixes constitui-se na principal via de exposição ambiental dos seres humanos e outros animais ao mercúrio, sendo as espécies de peixes com hábitos alimentares carnívoros e piscívoros as que possuem as maiores concentrações de mercúrio quando comparados aos outros níveis tróficos (BORRELL et al., 2014; GROTTO et al., 2010; MALM, 1998; PASSOS et al., 2003; FURNAS, 2005; ROULET et al., 1998, 1999).

É importante ressaltar que os organismos aquáticos são capazes de concentrar elementos traço com valores muito superiores aos observadas no ambiente (ROCHA, 1985). Dessa forma, o risco de contaminação das populações tradicionais dependentes do pescado é substancialmente elevado.

Além disso, inúmeras variáveis interferem na exposição das populações humanas ao mercúrio, as quais podem estar relacionadas tanto ao comportamento do mercúrio no ambiente, quanto ao consumo do pescado (locais de captura, espécies consumidas e sazonalidade) (BOISCHIO \& BARBOSA, 1993).

A absorção e biomagnificação do mercúrio nos peixes estão associadas à fisiologia de cada organismo e à forma química do mercúrio. Os peixes ao longo de sua evolução obtiveram a capacidade de organificar o mercúrio inorgânico, o qual é tóxico a esses animais. Dessa forma, a maior fração do mercúrio total (mais de 90\%) contido no tecido muscular de peixes está na forma de metilmercúrio, seu transporte até o tecido 
ocorre mediante a associação com o aminoácido cisteína (DIETZ et al., 2013; HONDA et al., 2006; IKINGURA \& AKAGI, 2003; PASSOS et al., 2007).

Já as formas inorgânicas do mercúrio possuem meia-vida biológica muito baixa (cerca de $10 \%$ ) e são pouco absorvidas pelo trato digestivo dos peixes, não sendo dessa forma, bioacumuladas. A Figura 3 ilustra bem o comportamento do mercúrio orgânico e inorgânico em peixes do reservatório de Lages, construído entre 1905 e 1908, no estado do Rio de Janeiro. O mercúrio inorgânico presente em sedimentos e materiais particulados em suspensão é incorporado pelos peixes detritívoros e alguns planctívoros, mas não sofre a bioacumulação como ocorre com o metilmercúrio absorvido pelos peixes carnívoros, piscívoros e onívoros (LACERDA \& MALM, 2008).

Figura 3 - Comportamento do mercúrio inorgânico e orgânico em peixes capturados no reservatório de Lages.

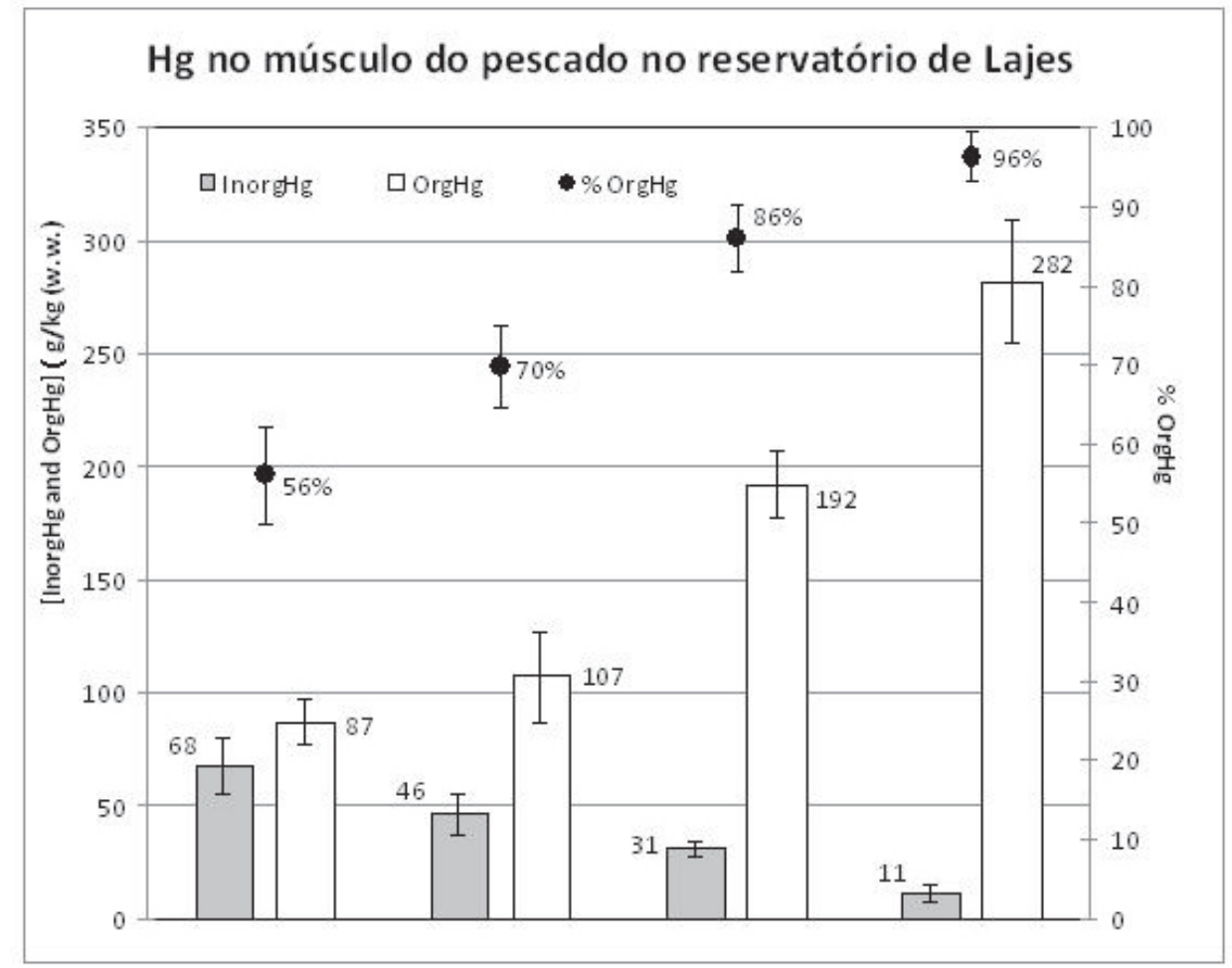

Fonte: LACERDA \& MALM, 2008.

No Brasil a Resolução RDC n 42, de $^{\circ} 9$ de agosto de 2013, dispõe sobre os limites máximos de contaminantes inorgânicos em alimentos. O regulamento preconiza para o elemento mercúrio em peixes não predadores a concentração máxima de 0,5 $\mathrm{mg} / \mathrm{kg}$ e em peixes predadores de $1,0 \mathrm{mg} / \mathrm{kg}$, para consumo humano. 
Um levantamento das concentrações de mercúrio total em amostras de tecido muscular de peixes oriundos de bacias hidrográficas e de reservatórios artificiais está sintetizado na Tabela 1.

Tabela 1 - Intervalos de concentrações de mercúrio total em amostras de músculos de peixes predadores e não predadores oriundos de bacias hidrográficas e reservatórios artificiais, de acordo com a literatura.

\begin{tabular}{|c|c|c|c|c|c|}
\hline Origem & Área de estudo & $\begin{array}{c}\text { Hábito } \\
\text { alimentar }\end{array}$ & $\begin{array}{c}\text { Número } \\
\text { de } \\
\text { amostras } \\
\end{array}$ & $\begin{array}{c}\text { Intervalo de } \\
\text { concentrações de } \\
\text { HgT (mg/kg) }\end{array}$ & $\begin{array}{l}\text { Autor(es)/ } \\
\text { Ano }\end{array}$ \\
\hline \multirow{21}{*}{$\begin{array}{l}\text { Ambientes } \\
\text { naturais }\end{array}$} & \multirow{6}{*}{$\begin{array}{l}\text { Rio Madeira, } \\
\text { Rondônia, Brasil }\end{array}$} & Predadores & 3 & $0,5-2,24$ & \multirow{2}{*}{$\begin{array}{l}\text { Martinelli et } \\
\text { al. (1988) }\end{array}$} \\
\hline & & Não predadores & 4 & $0,04-1,01$ & \\
\hline & & Predadores & 569 & \multirow{2}{*}{$0,34-0,36$} & \multirow{2}{*}{ Bastos (2004) } \\
\hline & & Não predadores & 224 & & \\
\hline & & Predadores & 888 & $0,002-4,75$ & \multirow{2}{*}{$\begin{array}{l}\text { Bastos et al. } \\
\quad(2006)\end{array}$} \\
\hline & & Não predadores & 233 & $0,001-0,90$ & \\
\hline & \multirow{2}{*}{$\begin{array}{l}\text { Rio Madeira, } \\
\text { Rondônia, Brasil }\end{array}$} & Predadores & 73 & $0,32-2,89$ & \multirow{2}{*}{$\begin{array}{l}\text { Malm et al. } \\
\text { (1995a) }\end{array}$} \\
\hline & & Não predadores & 52 & $0,02-0,5$ & \\
\hline & \multirow{2}{*}{$\begin{array}{c}\text { Rio Negro, } \\
\text { Amazonas, Brasil }\end{array}$} & Traíras & 45 & $0,055-1,008$ & \multirow{2}{*}{$\begin{array}{c}\text { Belger \& } \\
\text { Forsberg } \\
(2006)\end{array}$} \\
\hline & & Tucunarés & 49 & $0,031-1,469$ & \\
\hline & \multirow{4}{*}{$\begin{array}{c}\text { Rio Negro, } \\
\text { Amazonas, Brasil }\end{array}$} & Piscívoros & 560 & $0,015-5,437$ & \multirow{4}{*}{$\begin{array}{c}\text { Barbosa et al. } \\
\text { (2003) }\end{array}$} \\
\hline & & Onívoros & 172 & $0,005-0,778$ & \\
\hline & & Detritívoros & 59 & $0,16-0,450$ & \\
\hline & & Herbívoros & 63 & $0,002-0,186$ & \\
\hline & \multirow{2}{*}{$\begin{array}{c}\text { Rio Tapajós, Pará, } \\
\text { Brasil }\end{array}$} & Predadores & 65 & $0,04-3,77$ & $\begin{array}{l}\text { Malm et al. } \\
\text { (1995a) }\end{array}$ \\
\hline & & Predadores & 353 & $1,00-2,00$ & $\begin{array}{l}\text { Uryu et al. } \\
(2001)\end{array}$ \\
\hline & $\begin{array}{c}\text { Rios Acre e Purus, } \\
\text { Acre, Brasil } \\
\end{array}$ & Predadores & 673 & $0,07-13,00$ & $\begin{array}{l}\text { Silva et al. } \\
(2000)\end{array}$ \\
\hline & \multirow{2}{*}{$\begin{array}{l}\text { Lago Orbetello, } \\
\text { Itália }\end{array}$} & Predadores & 27 & $0,35-1,58$ & \multirow{2}{*}{$\begin{array}{c}\text { Miniero et al. } \\
\text { (2013) }\end{array}$} \\
\hline & & Não predadores & 27 & $0,28-2,54$ & \\
\hline & $\begin{array}{l}\text { Golfo Pérsico, } \\
\text { Médio Oriente }\end{array}$ & $\begin{array}{l}\text { Predadores e não } \\
\text { predadores }\end{array}$ & 80 & $0,05-0,40$ & $\begin{array}{l}\text { Raissy et } \\
\text { al.(2014) }\end{array}$ \\
\hline & Mashhad, Irã & $\begin{array}{c}\text { Clupeonella } \\
\text { cultriventris - } \\
\text { Cáspia } \\
\text { (Predador) }\end{array}$ & 8 & $0,55-1,53$ & $\begin{array}{l}\text { Vahabzadeh } \\
\text { et al. (2013) }\end{array}$ \\
\hline \multirow{2}{*}{$\begin{array}{l}\text { Reservatórios } \\
\text { artificiais }\end{array}$} & $\begin{array}{c}\text { São Samuel, rio } \\
\text { Jamari, Rondônia, } \\
\text { Brasil }\end{array}$ & Predadores & 27 & $0,07-1,10$ & $\begin{array}{l}\text { Silva et al. } \\
\text { (2012) }\end{array}$ \\
\hline & $\begin{array}{c}\text { Balbina, rio } \\
\text { Uatumã, } \\
\text { Amazonas, Brasil } \\
\end{array}$ & $\begin{array}{l}\text { Predadores e não } \\
\text { predadores }\end{array}$ & 43 & $0,02-1,10$ & $\begin{array}{l}\text { Kehrig et al. } \\
\qquad(1998)\end{array}$ \\
\hline
\end{tabular}


Tabela 1 - Intervalos de concentrações de mercúrio total em amostras de músculos de peixes predadores e não predadores oriundos de bacias hidrográficas e reservatórios artificiais, de acordo com a literatura_continuação.

\begin{tabular}{|c|c|c|c|c|c|}
\hline Origem & Área de estudo & $\begin{array}{l}\text { Hábito } \\
\text { alimentar }\end{array}$ & $\begin{array}{c}\begin{array}{c}\text { Número } \\
\text { de } \\
\text { amostras }\end{array} \\
\end{array}$ & $\begin{array}{c}\text { Intervalo de } \\
\text { concentrações de } \\
\text { HgT (mg/kg) } \\
\end{array}$ & $\begin{array}{c}\text { Autor(es)/ } \\
\text { Ano }\end{array}$ \\
\hline \multirow{9}{*}{$\begin{array}{l}\text { Reservatórios } \\
\text { artificiais }\end{array}$} & $\begin{array}{l}\text { Balbina, rio } \\
\text { Uatumã, }\end{array}$ & $\begin{array}{l}\text { Cichla spp. - } \\
\text { Tucunaré } \\
\text { (Predador) }\end{array}$ & 17 & $0,07-0,72$ & \multirow{4}{*}{$\begin{array}{l}\text { Kehrig et } \\
\text { al.(2009) }\end{array}$} \\
\hline & Amazonas, Brasil & $\begin{array}{c}\text { Geophagus } \\
\text { surinamensis - } \\
\text { Acará (Onívoro) }\end{array}$ & 11 & $0,04-0,10$ & \\
\hline & \multirow{2}{*}{$\begin{array}{c}\text { Tucuruí, rio } \\
\text { Tocantins, Pará, } \\
\text { Brasil }\end{array}$} & $\begin{array}{l}\text { Cichla spp. - } \\
\text { Tucunaré } \\
\text { (Predador) }\end{array}$ & 78 & $0,10-3,35$ & \\
\hline & & $\begin{array}{c}\text { Geophagus } \\
\text { surinamensis - } \\
\text { Acará (Onívoro) }\end{array}$ & 119 & $0,01-0,17$ & \\
\hline & $\begin{array}{c}\text { Manso, rio } \\
\text { Manso, Mato } \\
\text { Grosso, Brasil }\end{array}$ & $\begin{array}{l}\text { Predadores e não } \\
\text { predadores }\end{array}$ & 19 & $0,07-1,99$ & $\begin{array}{l}\text { Tuomola et } \\
\text { al. (2008) }\end{array}$ \\
\hline & \multirow{2}{*}{$\begin{array}{l}\text { Mtera, rio Great } \\
\text { Ruaha, Tanzânia }\end{array}$} & Predadores & 11 & $0,04-0,14$ & \multirow{4}{*}{$\begin{array}{c}\text { Ikingura \& } \\
\text { Akagi (2003) }\end{array}$} \\
\hline & & Não predadores & 6 & $0,006-0,06$ & \\
\hline & \multirow[t]{2}{*}{$\begin{array}{l}\text { Kidatu, rio Great } \\
\text { Ruaha,Tanzânia }\end{array}$} & Predadores & 7 & $0,02-0,12$ & \\
\hline & & Não predadores & 8 & $0,007-0,05$ & \\
\hline
\end{tabular}

HgT - mercúrio total.

As concentrações de mercúrio total na maioria dos estudos, sejam em ambientes naturais ou reservatórios artificias, estão acima dos limites preconizados na legislação. A maioria das pesquisas foi realizada na região norte do Brasil, onde o solo é rico em mercúrio natural e onde o uso desse elemento para extração do ouro é intenso (BASTOS et al., 2004; BELGER \& FORSBERG, 2006; LACERDA, 1995; MICARONI et al., 2000).

Em todos os trabalhos apresentados na Tabela 1, é possível observar que os peixes predadores acumularam mais mercúrio quando comparados aos peixes não predadores, evidenciando a ocorrência do processo de biomagnificação.

Além disso, em reservatórios artificiais a concentração de mercúrio, apesar de ser menor quando comparado aos ambientes naturais, ainda está em níveis preocupantes 
(Tabela 1). É importante ressaltar que é comum ocorrer aumentos acentuados de mercúrio em reservatórios recém-alagados, diminuindo o processo de metilação gradualmente ao longo do tempo (CANAVAN et al., 2000; PORVARI, 1995).

\subsection{TUCUNARÉS}

Os peixes são os vertebrados mais numerosos e antigos do mundo. São conhecidas mais de 20.000 espécies em regiões tropicais. Na região amazônica a diversidade de peixes é grande e ainda incerta, sendo comum a descrição de novas espécies. Segundo Anjos et al. (2008), são aproximadamente 2.400 espécies registradas e há um endemismo exacerbado nas cabeceiras dos rios. Considerando essa grande biodiversidade, pode-se inferir que a pesca comercial explore atualmente entre 2 e $10 \%$ de todas as espécies presentes (BARTHEM \& FABRÉ, 2004).

Segundo Barthem \& Fabré (2004) existem três grupos de espécies de peixes com comportamentos distintos, os não migradores ou sedentários que estão relacionados aos sistemas lacustres; os migradores que utilizam tanto os ambientes lacustres como os fluviais; e os grandes migradores que vivem nas calhas dos rios.

Os tucunarés possuem uma rota de migração pequena, o que os classificam como bons indicadores das características do ambiente. São peixes bem adaptados a ambientes lênticos com temperatura na faixa de 24 a $29{ }^{\circ} \mathrm{C}$ e pH ligeiramente ácido, dessa forma, são frequentemente encontrados em igarapés, represas, açudes e barragens (CASTILHOS et al., 2001).

Este peixe também possui grande capacidade de integrar grandes concentrações de mercúrio ao longo do tempo em função do seu tamanho relativamente grande e por ser um predador localizado no topo da cadeia trófica aquática. Além disso, possuem atratividade para pesca esportiva e carne de boa qualidade para consumo. Assim, os tucunarés são um dos indicadores mais sensíveis da bioacumulação do mercúrio em comunidades residentes, sobretudo na região amazônica (BASTOS et al., 2007; BASTOS et al., 2006; BELGER \& FORSBERG, 2006; BOISCHIO et al., 2000; DÓREA \& BARBOSA, 2007; KEHRIG et al., 2008).

Segundo Kullander \& Ferreira (2006) os tucunarés pertencem ao gênero Cichla e, em geral, são caracterizados por possuírem três linhas escuras na lateral e um ocelo redondo no pedúnculo caudal, algumas subespécies possuem uma mancha no opérculo e manchas pontilhadas por todo o corpo. Outra característica interessante é uma saliência occipital, mais conhecida como gibosidade, a qual é formada pelo acúmulo de tecido 
adiposo e é necessária para o processo de maturação ovocitária, período da desova e cuidados com a prole, época em que os adultos se alimentam com pouca frequência, conforme ilustrado na Figura 4.

Figura 4 - Principais estruturas que caracterizam o tucunaré.

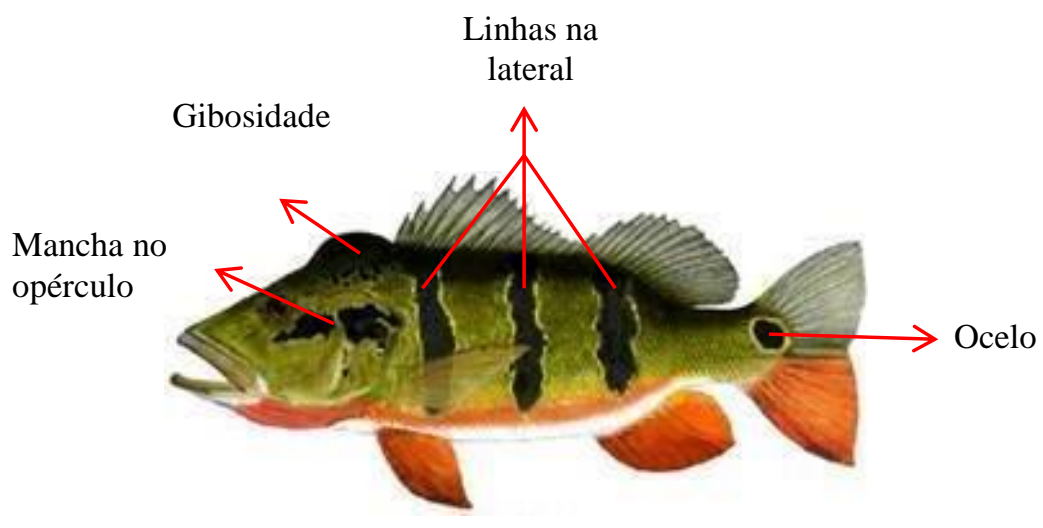

Fonte: Pescaria esportiva, 2010.

Os tucunarés praticam involuntariamente o canibalismo quando não conseguem identificar as presas como seus semelhantes, na maioria das vezes são filhotes sem o ocelo formado (KULLANDER \& FERREIRA, 2006).

A maturação dos tucunarés para ambos os sexos ocorre com 20 a $35 \mathrm{~cm}$ de comprimento ou com 1 ou 2 anos de idade (KEHRIG et al., 2008)

$\mathrm{Na}$ bacia do rio Madeira as subespécies de tucunarés comumente encontradas são Cichla monoculus, Cichla ocellaris e Cichla temensis (BASTOS et al., 2006; BOISCHIO et al., 2000).

Willis et al. (2007) investigaram os fatores que influenciam a diversificação de espécies de peixes neotropicais. Foram examinadas as relações filogenéticas entre as subespécies de tucunarés predominantes em mananciais do norte da América do Sul, mais especificadamente na Amazônia Brasileira. As subespécies mais comuns de Tucunarés foram mapeadas, dentre elas o Cichla monoculus, Cichla ocellaris, Cichla temensis, Cichla orinocensis, Cichla intermedia e algumas subespécies não identificadas Cichla sp. "Amazonas", "Xingu" e "Madeira". Nos rios Madeira e Negro as subespécies encontradas foram o Cichla monoculus e Cichla temensis, além do Cichla orinocensis que foi mapeado apenas no rio Negro.

Carvalho et al. (2009) identificaram a origem genética das populações invasoras de algumas subespécies de tucunarés, dentre elas o Cichla monoculus, encontrado nos rios Madeira e Negro e o Cichla temensis também coletado no rio Negro. 
A subespécie Cichla kelberi, foi recentemente descoberta e é encontrada com mais frequência na bacia do rio Tocantins (KULLANDER \& FERREIRA, 2006).

A Tabela 2 feita a partir da revisão proposta por Kullander \& Ferreira (2006), resume todas as 15 subespécies de tucunarés registradas no Brasil e os locais onde comumente são encontradas, bem como as respectivas referências.

Tabela 2 - Lista de subespécies de tucunarés, autores e anos e locais onde as subespécies são comumente encontradas.

\begin{tabular}{ccc}
\hline Subespécie & Autor, ano & Local de ocorrência \\
\hline Cichla ocellaris & Schneider, 1801 & $\begin{array}{c}\text { Bacia Amazônica, Costa Guiana; } \\
\text { Rio Essequibio }\end{array}$ \\
\hline Cichla temensis & Humboldt, 1821 & $\begin{array}{c}\text { Rio Negro; Rio Orinoco; Rio } \\
\text { Branco; Rio Purus }\end{array}$ \\
\hline Cichla orinocensis & Humboldt, 1821 & Rio Negro; Rio Orinoco \\
\hline Cichla monoculus & Agassiz, 1831 & $\begin{array}{c}\text { Bacia Amazônica; Rio } \\
\text { Amazonas, Peru }\end{array}$ \\
\hline Cichla nigromaculata & Jardine, 1843 & Rio Negro \\
\hline Cichla intermédia & Machado-Allison, 1971 & Rio Casiquiare \\
\hline Cichla kelberi & Kullander \& Ferreira, 2006 & Rio Tocantins \\
\hline Cichla pleizona & Kullander \& Ferreira, 2006 & Rio Guaporé \\
\hline Cichla mirianae & Kullander \& Ferreira, 2006 Tapajós \\
\hline Cichla melaniae & Kullander \& Ferreira, 2006 & Rio Xingu \\
\hline Cichla piquiti & Kullander \& Ferreira, 2006 & Rio Tocantins \\
\hline Cichla thyrorus & Kullander \& Ferreira, 2006 & Rio Trombetas \\
\hline Cichla jariina & Kullander \& Ferreira, 2006 & Rio Jari \\
\hline Cichla pinima & Kullander \& Ferreira, 2006 & Rio Curuá-Uma \\
\hline Cichla vazzoleri & Kullander \& Ferreira, 2006 & Rio Trombetas \\
\hline
\end{tabular}

\subsection{BIOMONITORAMENTO}

Biomonitoramento pode ser definido como uso sistemático de respostas biológicas para avaliar alterações no ambiente (ROSENBERG \& RESH, 1993). As características físicas, químicas e biológicas do ambiente podem gerar estresse e comprometer qualitativamente as espécies ou até mesmo provocar redução das populações. Medidas capazes de detectar essas alterações são ferramentas úteis para diagnóstico precoce da qualidade dos ambientes aquáticos e controle qualitativo e quantitativo dos recursos haliêuticos (WARREN, 1971).

A qualidade de um ambiente aquático pode ser definida quanto à presença de substâncias orgânicas e inorgânicas em diferentes especiações e concentrações presentes no corpo d'água (PELÁEZ-RODRIGUEZ, 2000).

Uma ótima ferramenta de biomonitoramento são os biomarcadores, os quais são instrumentos que possibilitam identificar a substância tóxica ou uma condição adversa 
antes que sejam evidenciados danos à saúde. Os biomarcadores podem ser classificados em três tipos: de exposição, de efeito e de suscetibilidade (AMORIM, 2003).

A seleção e uso adequado de biomarcadores são muito importantes para a gestão da saúde pública, sobretudo, nas ações de prevenção. Dentre as várias alternativas para monitoramento do mercúrio em humanos, amostras de saliva, unhas e cabelo são as menos invasivas e de fácil armazenamento e transporte (RODRIGUES et al., 2008).

Tanto o sangue quanto o cabelo, são considerados adequados biomarcadores de intoxicação em populações expostas ao mercúrio orgânico, as quais tem sua dieta baseada no consumo regular de peixes (CORREA et al., 2014; GROTTO et al., 2010; MALM, 1998). Nos trabalhos descritos por Boischio \& Barbosa (1993) e Malm (1998), foram observadas correlações entre metilmercúrio quantificado no cabelo e ingestão de peixes da região amazônica.

A biota é uma ferramenta muito utilizada para monitorar as mudanças temporais do ambiente (BORRELL et al., 2014). Os peixes, por exemplo, são bons bioindicadores da variabilidade ambiental e por isso são muito utilizados em estudos de monitoramento ambiental (BELGER \& FORSBERG, 2006).

Nesses organismos o mercúrio tende a acumular-se nas brânquias, cérebro, rins, músculo e fígado, este último é o órgão que mais absorve metilmercúrio, cerca de dez vezes mais quando comparado ao rim (BORRELL et al., 2014). Além disso, o fígado é o local onde os compostos xenobióticos são biotransformados, no caso do mercúrio orgânico, ocorre eventualmente sua desmetilação (DIETZ et al., 2013).

Devido à sua alta capacidade de acúmulo e baixa taxa de depuração, o músculo é considerado um monitor apropriado em casos de exposição crônica aos metais (JAHANBAKHT et al., 2002). Além disso, o músculo, mais conhecido popularmente como filé, também acumula metilmercúrio, é mais fácil de manipular em trabalhos de campo e em laboratório e é a parte dos peixes mais consumida pelas populações humanas.

\subsection{PROTEÍNAS}

Proteínas são macromoléculas constituídas por uma combinação de até 22 aminoácidos. Elas apresentam grande variedade estrutural devido ao número expressivo de possibilidades de sequências de aminoácidos (MORAES et al., 2013a).

Os aminoácidos formam ligações covalentes entre os grupos amino $\left(\mathrm{NH}_{2}\right)$ de um aminoácido e carboxílico $(\mathrm{COOH})$ de outro, essa reação é catalisada por um conjunto de 
enzimas, formando as ligações peptídicas. Assim, os aminoácidos geram cadeias polipeptídicas que ao atingirem certa extensão (cerca de 50 resíduos) recebem o nome de proteína (MORAES et al., 2013a).

Proteínas simples são aquelas constituídas apenas por uma cadeia de aminoácidos. Já as proteínas conjugadas, além dos aminoácidos, apresentam outros componentes químicos. Esse tipo de proteína é classificado de acordo com a natureza de seus grupos prostéticos (componente de natureza não proteica), onde as lipoproteínas apresentam lipídeos, as glicoproteínas contêm moléculas de açúcar e as metaloproteínas possuem em sua estrutura um íon metálico específico (MORAES et al., 2013a).

Existem muitas conformações diferentes para uma proteína, sua estrutura pode ser dividida em quatro diferentes níveis de organização: primário, secundário, terciário e quaternário, conforme apresentado na Figura 5.

Figura 5 - Níveis de organização estrutural das proteínas.

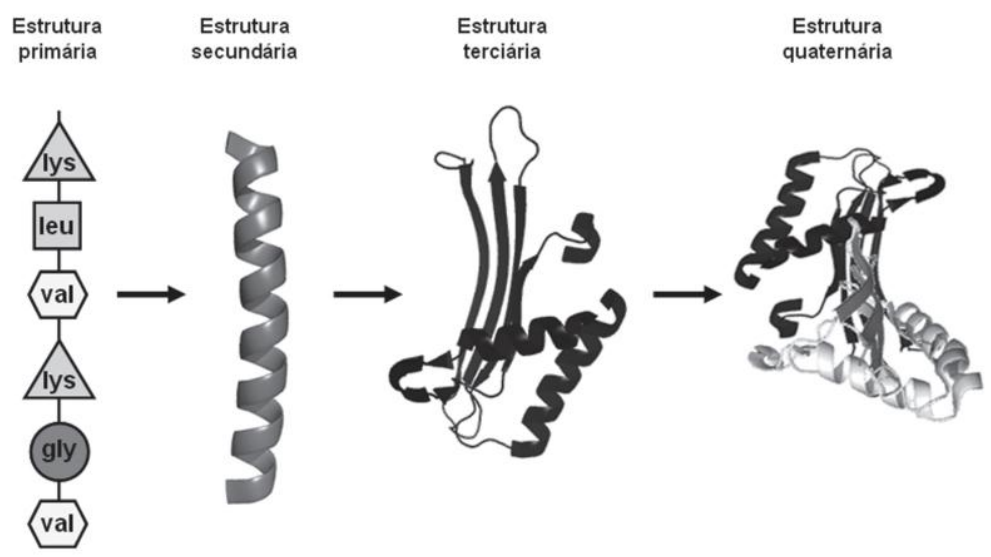

Fonte: Moraes et al. (2013a).

Segundo Moraes et al. (2013a), na estrutura primária a sequência de aminoácidos, unidos por ligações peptídicas, é linear. Esta estrutura resulta em uma longa cadeia de aminoácidos, com uma extremidade amino terminal (NH2) e uma extremidade carboxi terminal $(\mathrm{COOH})$.

O dobramento regular de regiões da cadeia polipeptídica é característico da estrutura secundária. Os dois tipos mais comuns desse tipo de estrutura são a alfa-hélice e folha beta-pregueada. As estruturas em alfa-hélice apresentam-se em aspecto cilíndrico com arranjo helicoidal de aminoácidos, que é mantido pelas ligações de hidrogênio paralelas ao eixo da hélice. Nas estruturas em folha beta-pregueada, as 
ligações de hidrogênio formam-se entre as regiões adjacentes do polipeptídio que estão na mesma direção ou em direções opostas (MORAES et al., 2013a).

A estrutura terciária refere-se ao arranjo tridimensional dos aminoácidos da cadeia polipeptídica. A forma nativa é mantida pelas múltiplas interações não covalentes que se formam entre os resíduos ou grupamentos que não contém aminoácidos. Além disso, a proteína precisa formar uma série de ligações nãocovalentes entre diferentes porções da cadeia polipeptídica e, em certos casos, é necessária a formação de ligações covalentes do tipo dissulfeto (LEHNINGER et al., 2011).

Ainda segundo os mesmo autores, na estrutura quaternária o arranjo espacial acontece entre duas ou mais cadeias polipeptídicas com estruturas terciárias definidas. A natureza da interação entre as diferentes cadeias é do tipo não-covalente gerando desde um dímero (duas cadeias) até um oligômero (mais de duas cadeias). Oligômeros podem ser do tipo homo oligômeros (subunidades com mesma estrutura primária) ou hetero oligômeros (diferentes estruturas primárias).

É importante ressaltar que quando as proteínas são extraídas do seu meio biológico original ficam expostas a muitos agentes que podem comprometer irreversivelmente suas estruturas. Sua integridade estrutural está intimamente relacionada ao $\mathrm{pH}$ e à temperatura do meio onde se encontram. Dessa forma, essas influências precisam ser cuidadosamente controladas e a manipulação das proteínas deve ser feita com agilidade (BRACHT et al., 2003).

Outro fator desestabilizante de proteínas em solução é a presença de proteases, enzimas que clivam as ligações peptídicas das proteínas. Entretanto, as proteases podem ser inibidas por agentes químicos sem que hajam prejuízos às atividades da proteína (BRACHT et al., 2003).

\subsection{METALÔMICA E TÉCNICAS DE FRACIONAMENTO}

A metalômica foi definida por Williams (2001) como campo científico sistemático de bio-metais e um complemento da genômica, proteômica e metabolômica. Em outras palavras, é o estudo das interações e conexões funcionais de íons metálicos e suas espécies com genes, proteínas, metabólitos e outras biomoléculas dentro dos organismos e dos ecossistemas.

Em estudos metaloproteômicos são utilizadas estratégias de seletividade, de sensibilidade e estrutural. 
Uma dos componentes de seletividade muito eficiente é a eletroforese bidimensional em gel de poliacrilamida (2D PAGE) para fracionamento das proteínas. A cromatografia líquida, a qual tem a capacidade de separar compostos não voláteis e a cromatografia bidimensional, também são comumente utilizadas (VOGIATZIS \& ZACHARIADIS, 2014).

A componente de sensibilidade muito empregada é a espectrometria de massa, a qual detecta e determina as concentrações de elementos e de moléculas.

A componente estrutural espectrometria de massas em sequência com ionização por eletrospray (ESI MS MS) é uma das mais robustas para caracterização das proteínas, pois garante a integridade das ligações fracas entre metais e metaloides, proteínas ou biomoléculas (VOGIATZIS \& ZACHARIADIS, 2014).

O fracionamento de proteínas baseado na massa molar pode ser feito por diálise, ultrafiltração e cromatografia de exclusão molecular, as quais, de modo geral, filtram as proteínas em solução por meio de membranas e peneiras moleculares (BRACHT et al., 2003).

Dependendo das propriedades acidobásicas, o fracionamento das proteínas também pode ser feito com base em sua carga elétrica, para tanto, além da 2D-PAGE anteriormente citada, tem-se a cromatografia de troca iônica.

De acordo com Bracht et al. (2003), a proteína em certo pH irá possuir uma carga líquida. Num valor baixo de $\mathrm{pH}$ essa carga será mais positiva e num valor mais alto de $\mathrm{pH}$ será mais negativa. $\mathrm{O} \mathrm{pH}$ no qual as cargas positivas e negativas se igualam, isto é, quando a carga efetiva da proteína é zero, define-se como o ponto isoelétrico da proteína (pI). Para que isso ocorra, é necessário que seja estabelecido um gradiente de pH entre o ânodo e o cátodo, tal gradiente é formado pela migração de substâncias polímeras denominadas anfólitos.

Ainda segundo os mesmos autores, um tipo particular de cromatografia de troca iônica é a focalização isoelétrica ou cromatofocalização, onde as proteínas são separadas como resultado da formação isocrática de um gradiente interno de $\mathrm{pH}$ nas colunas trocadoras de íons.

Há também a análise das frações proteicas por eletroforese, onde há migração de partículas carregadas em um determinado meio sob influência de um campo elétrico. Esse método possibilita a análise da heterogeneidade de proteínas em um determinado material e análise do grau de pureza de uma preparação. Além disso, por meio desse 
método podem-se obter os pontos isoelétricos e as massas molares das proteínas individualmente (BRACHT et al., 2003).

A utilização da eletroforese para separação de proteínas é remoto, iniciou-se no final da década de 1930. A primeira eletroforese empregada foi a eletroforese livre, na qual a solução tamponada da mistura proteica era inserida numa célula em formato de $U$ e um campo elétrico era estabelecido entre os eletrodos. Essa eletroforese foi suplantada pela eletroforese de zona, onde a solução proteica era imobilizada num material poroso e hidratado que apresentava uma rigidez mecânica, como o papel filtro e o acetato de celulose. Com a introdução de suportes que retardam ou excluem moléculas em função das massas molares, obteve-se uma melhor resolução eletroforética, sendo a poliacrilamida o suporte mais empregado desde a década de 1950 (BRACHT et al., 2003).

A poliacrilamida é um gel produto da polimerização vinílica da acrilamida e da N,N metileno-bis acrilamida, catalisada pela riboflavina ou pelo persulfato de amônio, esses dois catalizadores geram radicais livres, os quais são estabilizados por uma amina terciária, o TEMED (tetrametiletilenodiamina). Os radicais livres formados reagem com a acrilamida ativando-a, esta reage com outras moléculas de acrilamida produzindo uma longa cadeia linear do polímero. A bis-acrilamida atua na criação de ligações cruzadas entre as cadeias lineares, originando uma rede que resulta na formação do gel (BRACHT et al., 2003).

A eletroforese em gel de poliacrilamida-dodecilsultafo de sódio (SDS-PAGE) é um dos procedimentos que separam as proteínas com base em suas massas molares. $\mathrm{O}$ SDS liga-se às porções hidrofóbicas das proteínas e rompe suas dobras, permitindo que as proteínas existam em conformação estendida estável. O tamanho do complexo proteína-SDS é proporcional à sua massa molar (BRACHT et al., 2003).

A eletrofose com SDS pode ser desnaturante, quando as proteínas são inicialmente superaquecidas ou reduzidas, esses procedimentos separam suas subunidades e permite determinar a massa molar das proteínas. Para tanto, padrões proteicos de massas molares conhecidas também são aplicados no gel. Outra forma de SDS é a não-desnaturante, onde não há superaquecimento e nem ação de agentes redutores, as proteínas resistentes ao SDS são recuperadas e, caso a proteína seja uma enzima é possível localizar sua posição no gel (BRACHT et al., 2003). 
É importante destacar que antes de aplicar as técnicas de separação, é necessário que as amostras sejam purificadas e/ou isoladas, após o pré-tratamento da amostra (extração, liofilização, centrifugação ou filtração).

\section{OBJETIVOS}

\subsection{OBJETIVO GERAL}

Identificação de possíveis biomarcadores de exposição ao mercúrio em tucunarés, através de métodos metaloproteômicos, de forma a contribuir na elucidação da dinâmica desse elemento nos organismos e na construção de futuras ferramentas de biomonitoramento.

\subsection{OBJETIVOS ESPECÍFICOS}

- Quantificar mercúrio total em tecido muscular de tucunarés oriundos dos rios Negro, Apuaú, Solimões, Purus e Madeira e dos reservatórios das usinas hidrelétricas de Balbina, Cana Brava e Tucuruí;

- Quantificar mercúrio nas proteínas precipitadas da subespécie de tucunarés que apresentaram as maiores concentrações de mercúrio total na musculatura;

- Separar as proteínas de acordo com seus pontos isoelétricos (pI) e otimizar procedimentos de separação das proteínas por massas molares;

- Quantificar mercúrio nos spots proteicos encontrados na etapa de separação das proteínas.

\section{MATERIAIS E MÉTODOS}

\subsection{CARACTERIZAÇÃO DAS ÁREAS DE ESTUDO}

As amostragens de tucunarés foram realizadas nos rios Negro e Purus, em Manaus, capital do Amazonas; no rio Apuaú, num município do Amazonas denominado Novo Airão; duas amostragens foram feitas no rio Solimões, uma no município de Codajás e outra em Coari, também localizados no estado do Amazonas; na área de influência da UHE Jirau, a qual está instalada no rio Madeira, em Porto Velho, capital de Rondônia; no reservatório da UHE Balbina, situada no rio Uatumã, município de Presidente Figueiredo, estado do Amazonas; na UHE Tucuruí construída no rio Tocantins, município de Tucuruí, no Pará e; na UHE Cana Brava também localizada no rio Tocantins, mas no município de Minaçu, em Goiás (Figura 6). 
Figura 6 - Mapa de localização das coletas de tucunarés.

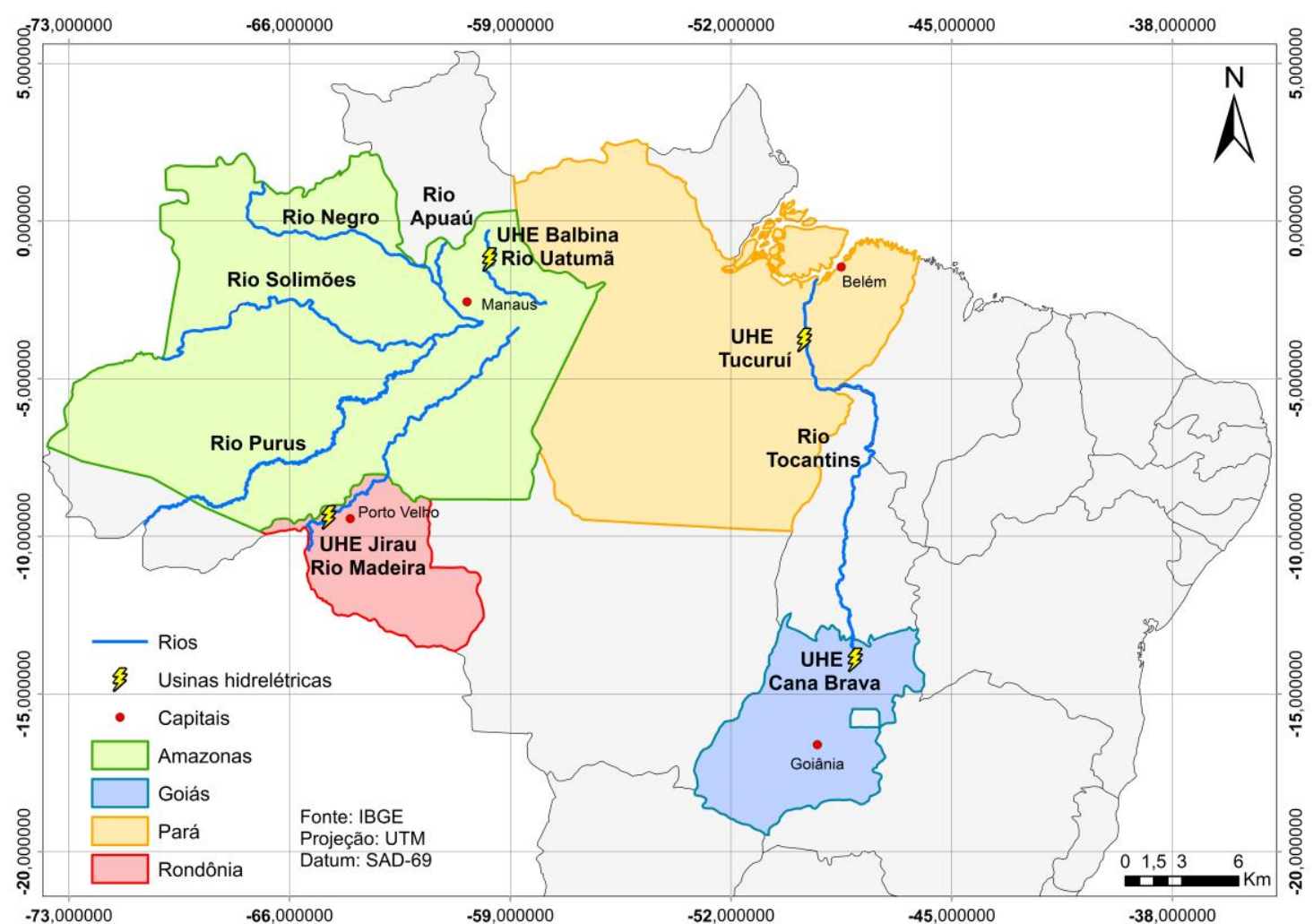

\subsubsection{Rio Negro}

O rio Negro nasce na região pré-andina colombiana que separa a Colômbia da Venezuela, onde é denominado Guainía, e chega ao Brasil pelo estado do Amazonas (SANTOS et al., 2005). Este rio possui extensão de aproximadamente $1.700 \mathrm{~km}$, sua vazão é de 29.000 m³/s em Manaus, onde forma o rio Amazonas após encontro com o rio Solimões (FADINI \& JARDIM, 2001).

A bacia do rio Negro compreende uma área de $690.000 \mathrm{~km}^{2}$, representando $14 \%$ da área total da Amazônia Brasileira e com altitudes que variam de 0 a 100 m acima do nível do mar. Dentre os diversos tipos de solos argilosos, antigos e profundos, o horizonte $\mathrm{B}$ de latossolos predominam nessa região. Além disso, o clima é quente e úmido, com temperaturas variando entre 26 e $28{ }^{\circ} \mathrm{C}$ e no período chuvoso (maio a junho) a média de precipitações é de $2.000 \mathrm{~mm}$ (BARBOSA et al., 2003; FADINI \& JARDIM, 2001; DA SILVA et al., 2006). 


\subsubsection{Rio Apuaú}

O rio Apuaú é um dos tributários da margem esquerda do rio Negro, apresenta águas escuras, ricas em matéria orgânica, e possui características físico-químicas muito semelhantes às do rio Negro.

Os solos da bacia do rio Apuaú são arenosos e em alguns locais são arenoargilosos de textura fina. A amplitude da terra inundada é inteiramente revestida por arbustos e pequenas arvoretas de alturas iguais, sendo a vegetação de Caatinga-gapó ou Campina inundável, a predominante nessa região (IBAMA, 1999).

O município de Novo Airão tem uma superfície de $38.706 \mathrm{~km}^{2}$ e cerca $80 \%$ do seu território abrangem unidades de conservação e áreas indígenas. As comunidades que vivem da agricultura de subsistência e do extrativismo vegetal, da borracha, da castanha e da madeira. A infraestrutura pública é mínima, dependendo principalmente dos serviços do município de Novo Airão (IBAMA, 1999).

\subsubsection{Rio Solimões}

As nascentes do rio Solimões estão localizadas nos Andes. A área da bacia do rio Solimões é de $2.200 .000 \mathrm{~km}^{2}$, a profundidade média do rio Solimões está entre $20 \mathrm{e}$ $35 \mathrm{~m}$, a vazão média é de $100.000 \mathrm{~m}^{3}$ /s (FRANZINELLI, 2011).

O rio Solimões é um dos maiores rios de águas brancas do Brasil, essa coloração deve-se à turbidez elevada, acima de $100 \mathrm{mg} / \mathrm{L}$ de sólidos suspensos, como argilas, siltes e areias finas. Além disso, são águas relativamente ricas em nutrientes e íons, o que as confere uma condutividade elétrica variando entre 64 e $75 \mu{\mathrm{S} . \mathrm{cm}^{-1}}^{-}$e o pH está próximo do neutro, entre 6,7 e 6,9 (SIOLI, 1984).

O clima na bacia do rio Solimões, é bem semelhante ao da bacia amazônica, sendo quente e úmido, com precipitação pluvial anual igual ou superior a $2.000 \mathrm{~mm}$ e com médias anuais de temperatura e umidade relativa de $27{ }^{\circ} \mathrm{C}$ e $84 \%$, respectivamente (GUIMARÃES et al., 2013).

\subsubsection{Rio Purus}

Os riachos peruanos Curiuja e Cujar localizados a cerca de $500 \mathrm{~m}$ de altitude são os principais formadores do rio Pucani, denominado no Brasil como rio Purus. Esse rio é afluente da margem direita do rio Solimões, possui grande extensão $(3.325 \mathrm{~km})$ e é caracterizado pela abundante carga de sedimentos e cursos sinuosos. O total das áreas 
alagavéis do rio Purus é de $21.833 \mathrm{~km}^{2}$ e sua cheia ocorre entre os meses de novembro a maio (REIS et al., 2009).

A área de drenagem é de aproximadamente $372.000 \mathrm{~km}^{2}$ e em território acreano a bacia apresenta uma área de $43.897 \mathrm{~km}^{2}$. Gleissolos e a floresta aberta aluvial com predominância de palmeiras caracterizam a região (REIS et al., 2009).

A bacia do rio Purus é ocupada em mais de $60 \%$ com unidades de conservação e terras indígenas, estima-se que a população ribeirinha seja constituída de 12.854 pessoas. Os impactos nessa bacia se resumem à exploração madeireira, desmatamento para agricultura e assentamentos, instalação de indústrias de torrefação de café, lançamento de efluentes sem tratamento provenientes de domicílios e matadouros, pavimentação da rodovia BR-319, localizada ao sul do Amazonas, e caça e pesca em larga escala. De 1976 a 1998, a atividade pesqueira passou de 15,7\% para 49,3\% (REIS et al., 2009).

A ictiofauna desse rio foi inicialmente investigada por La Monte (1935), que registrou apenas 29 espécies. Cox-Fernandes (1995), 60 anos mais tarde, acrescentou 13 espécies a essa lista. Mais recentemente, Anjos et al. (2008) coletaram 735 peixes de 86 espécies.

\subsubsection{Rio Madeira}

O rio Madeira nasce na Cordilheira dos Andes e é afluente da margem direita do rio Amazonas, com uma extensão de $1.390 .000 \mathrm{~km}^{2}$ (DÓREA \& BARBOSA, 2007). Este rio possui elevada carga de materiais em suspensão e transporte de sedimentos que provém desses vales. Além disso, contribui com cerca de 50\% da carga total de material suspenso transportado pelo rio Amazonas, a qual varia de 248 a 600 milhões de toneladas ao ano (BASTOS et al., 2007). As áreas alagáveis da bacia do rio Madeira compreendem uma área de $8.189 \mathrm{~km}^{2}$ e as precipitações variam de 2.000 a $2.200 \mathrm{~mm}$ por ano. (BARTHEM \& FABRÉ, 2004).

O local onde foram coletados os tucunarés compreende a área de influência da Usina Hidrelétrica Jirau, a qual ainda está finalizando a instalação e está operando parcialmente. A Usina terá capacidade máxima instalada de 3.750 Megawatts (MW), a área do reservatório compreende $361,6 \mathrm{~km}^{2}$ e a área inundada varia entre 31 e 108 km² (Energia Sustentável do Brasil, 2013).

Além dos empreendimentos hidrelétricos, a bacia do Rio Madeira, nos últimos 30 anos, tem sido impactada pelos desmatamentos para projetos de agricultura e 
extração de ouro por meio de garimpos, os quais contribuem na disponibilidade de $\mathrm{Hg}$ para o ambiente e toda a biota da região (BASTOS et al., 2007).

\subsubsection{Usina Hidrelétrica Balbina}

A UHE Balbina entrou em operação em fevereiro de 1989 no rio Uatumã, no município de Presidente Figueiredo, há cerca de $180 \mathrm{~km}$ ao nordeste de Manaus. A potência instalada é de 200 a 500 MW (KASPER et al., 2014; MüLLER, 1994; SILVA et al., 2008).

A bacia hidrográfica do rio Uatumã situa-se entre os estados do Amazonas e Roraima, totalizando uma área de drenagem de $70.600 \mathrm{~km}^{2}$. O clima da região é tropical úmido, com precipitação anual de $2.000 \mathrm{~mm}$ entre os meses de dezembro a maio (SILVA et al., 2008).

O reservatório da UHE Balbina está rodeado por floresta tropical com algumas pequenas comunidades e com a vila de Balbina. A atividade pesqueira no reservatório é intensa, sendo a espécie tucunaré predominante na região (MüLLER, 1994). O consumo de tucunarés nessa região varia de 1 a 7 vezes por semana, sendo o consumo médio diário per capita de 110 g para adultos (KASPER et al., 2014).

A construção dessa usina trouxe inúmeros problemas ambientais, sobretudo devido ao alagamento de $2.137 \mathrm{~km}^{2}$ de floresta virgem, com a profundidade média de $8,8 \mathrm{~m}$, sendo a área total da usina de $4.438 \mathrm{~km}^{2}$ (MüLLER, 1994).

\subsubsection{Usina Hidrelétrica Cana Brava}

A UHE Cana Brava iniciou sua operação em maio de 2002 no rio Tocantins, entre as cidades de Minaçu, Cavalcante e Colinas do Sul, no estado de Goiás. A usina possui um reservatório de $139 \mathrm{~km}^{2}$, com o potencial de gerar $450 \mathrm{MW}$. O lago artificial de Cana Brava cerca a praia do sol, uma das principais atrações turísticas do município de Minaçu (IBAMA, 2012).

O rio Tocantins nasce na Serra Paranã, há aproximadamente $1.100 \mathrm{~m}$ de altitude, próximo a Brasília e percorre cerca de $2.400 \mathrm{~km}$ até sua foz em Belém do Pará. A vazão média do rio Tocantins na confluência com o rio Araguaia é de $7.860 \mathrm{~m}^{3} / \mathrm{s}$ na cheia a $784 \mathrm{~m}^{3} / \mathrm{s}$ na vazante (MIRANDA \& MAZZONI, 2009).

$\mathrm{Na}$ bacia desse rio o regime hidrológico é bem definido, com período de águas altas de outubro a abril e período de águas baixas de maio a setembro, sendo que a precipitação anual varia entre 1.500 e $2.000 \mathrm{~mm}$. A média da temperatura anual é de 24 
${ }^{\circ} \mathrm{C}$ e a umidade relativa do ar é em média de 60\% (MIRANDA \& MAZZONI, 2009; SILVA \& SCARIOT, 2003).

É uma região composta por planaltos e chapadas, com altitudes que variam de 400 a 600 m. Onde há criação de muitas áreas de pastagem e agricultura, e intensa exploração de madeira (SILVA \& SCARIOT, 2003).

\subsubsection{Usina Hidrelétrica Tucuruí}

A área do reservatório da UHE Tucuruí é de aproximadamente $2.830 \mathrm{~km}^{2}$, com um comprimento de $170 \mathrm{~km}$ no eixo norte-sul e nível máximo de água de $14 \mathrm{~m}$. Além disso, a usina foi construída na cota de 72 metros, com perímetro de $7.700 \mathrm{~km}$ e formou cerca de 1.600 ilhas (PORVARI, 1995; SANCHES \& FISCH, 2005).

O barramento completo do rio ocorreu em setembro de 1984 e o enchimento do reservatório prolongou-se até março de 1985. A Usina, com capacidade de gerar 8370 MW, está situada no baixo rio Tocantins, entre as cidades de Cametá e Marabá no estado do Pará e há cerca de $110 \mathrm{~km}$ a nordeste da área de mineração de ouro denominada Serra Pelada (QUEIROZ et al., 2012; SANTANA et al., 2014).

Na região onde fora construída a UHE Tucuruí, inicialmente, a oxigenação da água estava acima de $7 \mathrm{mg} / \mathrm{L}$, o pH possuía valores entre 6,5 e 8,1 , a condutividade elétrica era baixa $(<50 \mathrm{~s} / \mathrm{cm})$ e a transparência variava entre $20 \mathrm{~cm}$ e $200 \mathrm{~cm}$, características de um rio de águas brancas. Contudo, essas condições foram alteradas após a construção da barragem e o desenvolvimento da ictiofauna, a qual era diversificada e abundante, foi comprometido (SANTANA et al., 2014).

Entre 1991 e 2000, houve migração das comunidades que viviam na zona rural para os centros urbanos, provavelmente por influência das transformações ambientais, econômicas e de ocupação e uso do solo ocorridas no entorno da UHE Tucuruí. A população urbana que era de 46.014 em 1991 aumentou para 85.426 em 2007, já a rural, nesse mesmo período, decresceu de 35.609 para 3.838 pessoas (QUEIROZ et al., 2012). Ainda segundo os mesmos autores, as principais atividades econômicas desenvolvidas na região são o extrativismo vegetal e a pecuária. 


\subsection{COLETA DAS AMOSTRAS}

As coletas dos tucunarés foram feitas por pescadores locais e as amostras de tecido muscular foram retiradas de 58 tucunarés de 8 diferentes subespécies, entre outubro de 2013 e 2014. Foi realizada uma única amostragem em cada rio, com exceção dos rios Negro, Solimões e Tocantins onde foram feitas duas amostragens em diferentes regiões.

As regiões onde os tucunarés foram coletados, bem como as subespécies, número de espécimes, métodos de captura e data de cada amostragem estão sintetizados na Tabela 3.

Tabela 3 - Local da coleta, subespécie, número de espécimes, método de captura e data da amostragem dos tucunarés oriundos dos rios Negro, Apuaú, Solimões, Purus e Madeira, e reservatórios das usinas hidrelétricas Balbina, Cana Brava e Tucuruí.

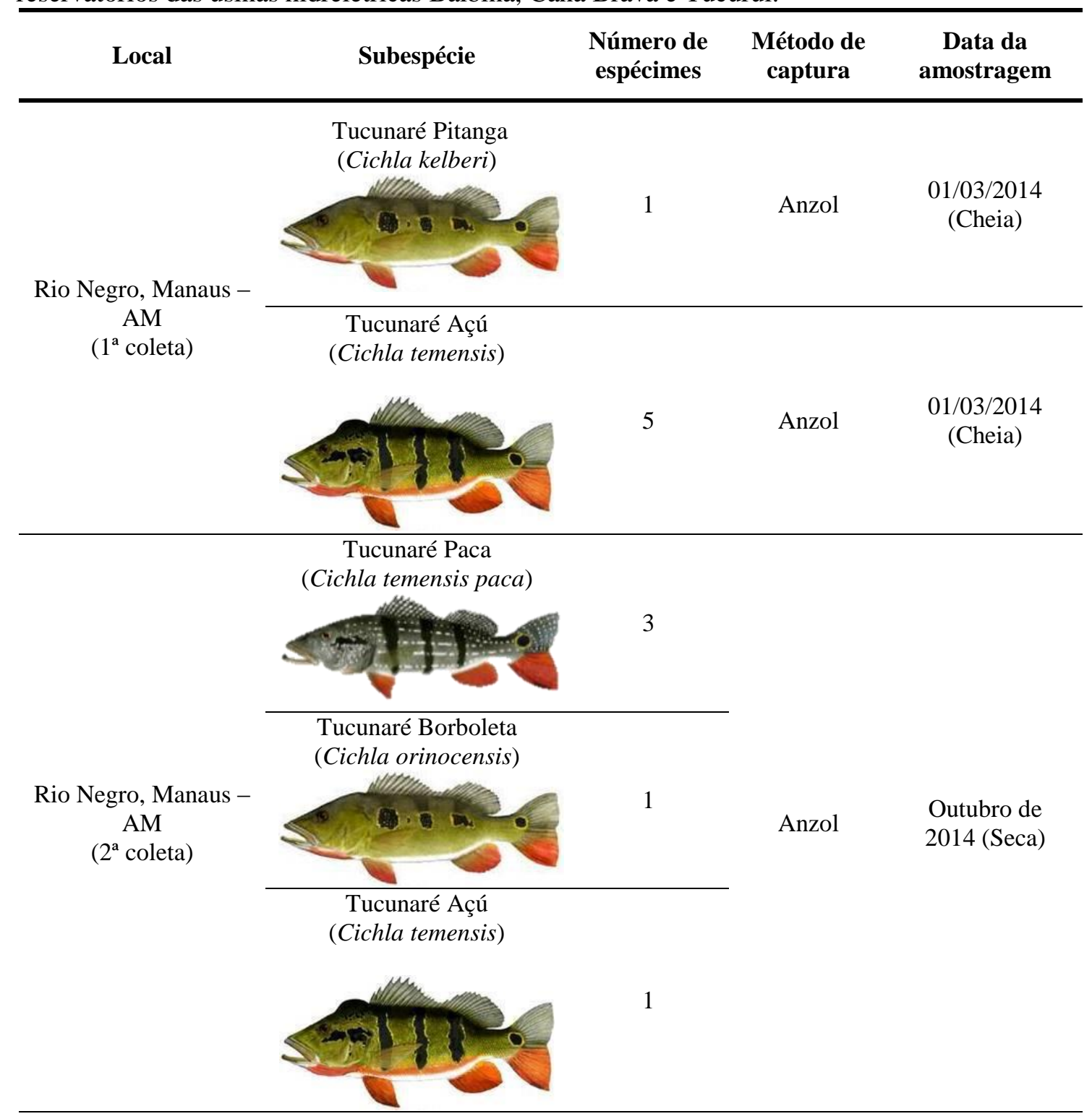


Tabela 3 - Local da coleta, subespécie, número de espécimes, método de captura e data da amostragem dos tucunarés oriundos dos rios Negro, Apuaú, Solimões, Purus e Madeira, e reservatórios das usinas hidrelétricas Balbina, Cana Brava e Tucuruí_continuação.

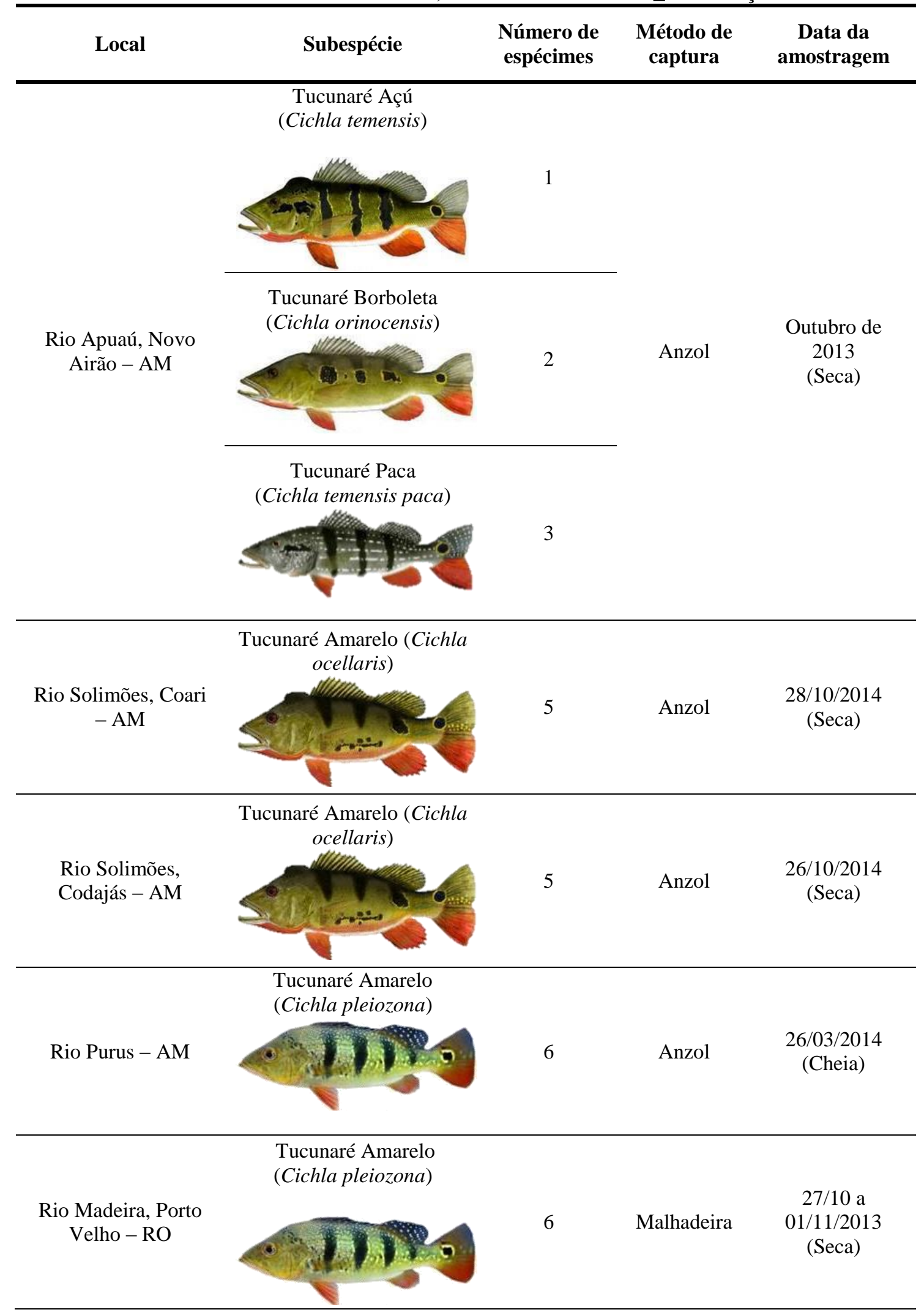


Tabela 3 - Local da coleta, subespécie, número de espécimes, método de captura e data da amostragem dos tucunarés oriundos dos rios Negro, Apuaú, Solimões, Purus e Madeira, e reservatórios das usinas hidrelétricas Balbina, Cana Brava e Tucuruí_continuação.

\begin{tabular}{|c|c|c|c|c|}
\hline Local & Subespécie & $\begin{array}{l}\text { Número de } \\
\text { espécimes }\end{array}$ & $\begin{array}{l}\text { Método de } \\
\text { captura }\end{array}$ & $\begin{array}{c}\text { Data da } \\
\text { amostragem }\end{array}$ \\
\hline $\begin{array}{c}\text { Rio Uatumã - AM } \\
\text { (Reservatório da } \\
\text { UHE Balbina) }\end{array}$ & $\begin{array}{l}\text { ucunaré } \\
\text { chla vazz }\end{array}$ & 7 & Anzol & $\begin{array}{c}\text { 28/03/2014 } \\
\text { (Cheia) }\end{array}$ \\
\hline $\begin{array}{c}\text { Rio Tocantins - GO } \\
\text { (Reservatório da } \\
\text { UHE Cana Brava) }\end{array}$ & $\begin{array}{l}\text { Tucunaré Azu } \\
\text { Cichla piquit }\end{array}$ & 6 & Anzol & $\begin{array}{c}17 / 03 \mathrm{a} \\
21 / 03 / 2014 \\
\text { (Cheia) }\end{array}$ \\
\hline $\begin{array}{c}\text { Rio Tocantins - PA } \\
\text { (Reservatório da } \\
\text { UHE Tucuruí) }\end{array}$ & & 6 & Anzol & $\begin{array}{l}\text { Outubro de } \\
2014 \text { (Seca) }\end{array}$ \\
\hline
\end{tabular}

Após capturados, os peixes foram eutanasiados, seus dados biométricos (comprimento e peso totais) foram medidos e aproximadamente $100 \mathrm{~g}$ do músculo branco dorso lateral de cada espécime foi removido com o auxílio de pinça e bisturi (Figura 7 e 8).

Figura 7 - Coleta dos dados biométricos do tucunaré açú capturado no rio Negro.

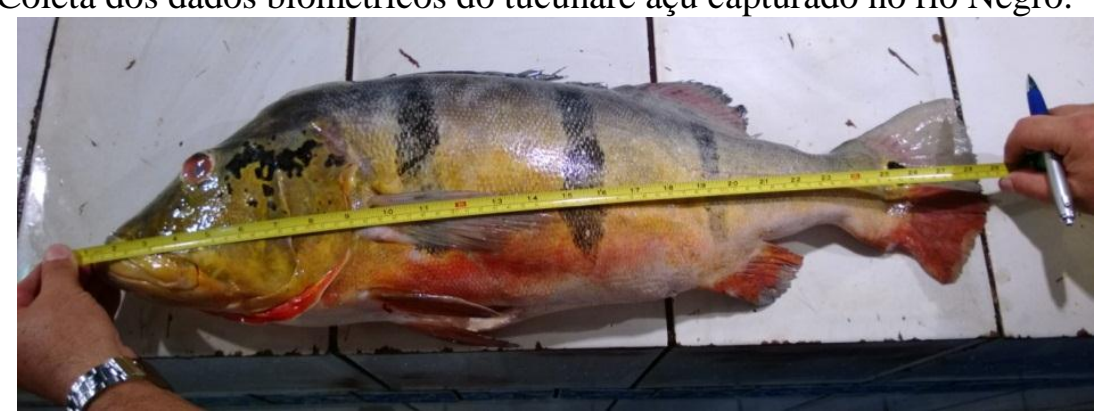


Figura 8 - Remoção do músculo branco dorso lateral do tucunaré azul capturado no reservatório da Usina Hidrelétrica Cana Brava.

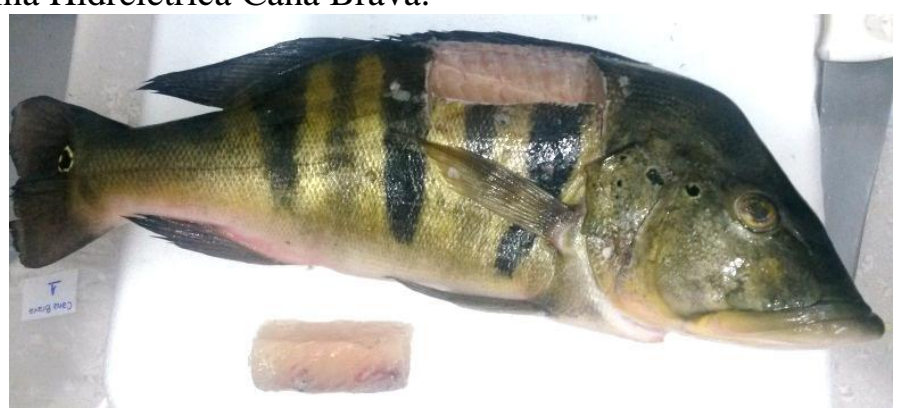

As amostras de músculos foram acondicionadas em frascos de polietileno, congeladas e armazenadas à $-25{ }^{\circ} \mathrm{C}$ para posteriores análises no Laboratório de Bioanalítica e Eletroforese do Instituto de Biociências da Universidade Estadual Paulista Júlio de Mesquita Filho - UNESP, Botucatu-SP.

\subsection{EQUIPAMENTOS E ACESSÓRIOS}

Todos os equipamentos e acessórios utilizados neste estudo estão apresentados na Tabela 4.

Tabela 4 - Listagem dos equipamentos e acessórios utilizados durante as análises laboratoriais, bem como as marcas, os modelos e os locais de origem.

\begin{tabular}{lll}
\hline Equipamento / Acessório & Marca & Modelo \\
\hline Agitador por efeito vórtex & Vivax & VortexMixer AC \\
\hline Agitador magnético & Corning & PC-420 \\
\hline Balança analítica & Gehaka & BG - 400 \\
\hline Banho maria & Unique & USC-18000A \\
\hline Caixa para hidratação de fitas de eletroforese & $\begin{array}{l}\text { General Electric Company } \\
\text { Healthcare }\end{array}$ & IPGBOX \\
\hline Cuba para eletroforese do tipo 2D-PAGE & $\begin{array}{l}\text { General Electric Company } \\
\text { Healthcare }\end{array}$ & \multirow{2}{*}{ SE 600 Ruby Complete } \\
\hline Espectrofotômetro UV/Visível & ThermoSpectronic & Evolution 60 \\
\hline Espectrômetro de absorção atômica & SHIMADZU & AA 6800 \\
\hline Espectrômetro de absorção atômica & Perkin Elmer & SMS 100 \\
\hline Forno de microondas & Eletrolux & SW-4, \\
série n 000435
\end{tabular}




\subsection{REAGENTES E SOLUÇÕES}

A vidraria utilizada foi mantida em ácido nítrico a $10 \%$ (v/v) por aproximadamente 12 horas, e posteriormente, lavada com água ultrapura. O material utilizado na eletroforese, tais como cuba, espaçadores e vidros foram lavados com água ultrapura e submetidos à limpeza com etanol antes de sua utilização. Além disso, é importante ressaltar que em todos os procedimentos laboratoriais foram utilizados máscara, luvas e touca. A Tabela 5 lista os reagentes e soluções utilizados neste estudo.

Tabela 5 - Reagentes e soluções utilizados nas análises deste estudo, bem como suas fórmulas químicas, massas molares, fabricantes e locais de origem.

\begin{tabular}{|c|c|c|c|}
\hline Reagente / Solução & Fórmula química & $\begin{array}{c}\text { Massa molar } \\
(\mathrm{g} / \mathrm{mol})\end{array}$ & Fabricante \\
\hline Acetona P.A. & $\mathrm{C} 3 \mathrm{H} 6 \mathrm{O}$ & 58,08 & Synth \\
\hline Ácido acético glacial & $\mathrm{C}_{2} \mathrm{H}_{4} \mathrm{O}_{2}$ & 60,05 & J.T. Baker \\
\hline Ácido clorídrico & $\mathrm{HCl}$ & 36,46 & J.T. Baker \\
\hline $\begin{array}{l}\text { Ácido etilenodiaminotetracético } \\
\text { dipotássico }\left(\mathrm{K}_{2} \text { EDTA) }\right.\end{array}$ & $\mathrm{C}_{10} \mathrm{H}_{14} \mathrm{O}_{8} \mathrm{~N}_{2} \mathrm{~K}_{22} \mathrm{H}_{2} \mathrm{O}$ & 404,46 & Merck \\
\hline Ácido fosfórico $85 \%$ & $\mathrm{H}_{3} \mathrm{PO}_{4}$ & 98,00 & Merck \\
\hline Ácido nítrico & $\mathrm{HNO}_{3}$ & 63,01 & Merck \\
\hline Acrilamida & $\mathrm{C}_{3} \mathrm{H}_{5} \mathrm{NO}$ & 71,08 & General Electric \\
\hline Agarose & $\begin{array}{l}\text { grau biologia } \\
\text { molecular }\end{array}$ & & BioAgency \\
\hline Albumina de soro bovino & - & - & Merck \\
\hline Anfólitos, pH de 3 a 10 & - & - & $\begin{array}{c}\text { Amersham } \\
\text { Biosciences }\end{array}$ \\
\hline Azul de bromofenol & $\mathrm{C}_{19} \mathrm{H}_{9} \mathrm{Br}_{4} \mathrm{NaO}_{5} \mathrm{~S}$ & 691,94 & BioAgency \\
\hline Coomassie blue G-250 & $\mathrm{C}_{47} \mathrm{H}_{50} \mathrm{~N}_{3} \mathrm{NaO}_{7} \mathrm{~S}_{2}$ & 854,03 & J.T. Baker \\
\hline Ditiotreitol (DTT) & $\mathrm{C}_{4} \mathrm{H}_{10} \mathrm{O}_{2} \mathrm{~S}_{2}$ & 154,24 & $\begin{array}{l}\text { Amersham } \\
\text { Biosciences }\end{array}$ \\
\hline Dodecil sulfato de sódio (SDS) & $\mathrm{C}_{12} \mathrm{H}_{25} \mathrm{OSO}_{3} \mathrm{Na}$ & 288,38 & General Electric \\
\hline Etanol & $\mathrm{C}_{2} \mathrm{H}_{6} \mathrm{O}$ & 46,07 & J.T. Baker \\
\hline $\begin{array}{l}\text { Fitas para focalização isoelétrica } \\
\text { com anfólitos imobilizados de } \mathrm{pH} 3 \\
\text { a } 10\end{array}$ & - & - & General Electric \\
\hline Glicerol 87\% & $\mathrm{C}_{3} \mathrm{H}_{8} \mathrm{O}_{3}$ & 92,09 & $\begin{array}{c}\text { Amersham } \\
\text { Biosciences }\end{array}$ \\
\hline Iodoacetamida & $\mathrm{C}_{2} \mathrm{H}_{4} \mathrm{INO}$ & 184,96 & General Electric \\
\hline Metanol & $\mathrm{CH}_{4} \mathrm{O}$ & 32,04 & J.T. Baker \\
\hline N, N'-metilenobisacrilamida & $\mathrm{C}_{7} \mathrm{H}_{10} \mathrm{~N}_{2} \mathrm{O}_{2}$ & 154,17 & General Electric \\
\hline $\begin{array}{l}\text { N, N', N, N'-tetrametilenodiamina } \\
\text { (TEMED) }\end{array}$ & $\mathrm{C}_{6} \mathrm{H}_{16} \mathrm{~N}_{2}$ & 116,20 & General Electric \\
\hline Óleo mineral & - & - & General Electric \\
\hline Padrão proteico de massa molar & - & - & General Electric \\
\hline Persulfato de amônio & $\mathrm{N}_{2} \mathrm{H}_{8} \mathrm{~S}_{2} \mathrm{O}_{8}$ & 228,20 & General Electric \\
\hline Sulfato de amônio & $\mathrm{H}_{8} \mathrm{~N}_{2} \mathrm{O}_{4} \mathrm{~S}$ & 132,14 & J.T. BACKER \\
\hline Tiouréia & $\mathrm{CH}_{4} \mathrm{~N}_{2} \mathrm{~S}$ & 76,12 & General Electric \\
\hline Tris-hidroximetil amino metano & $\mathrm{C}_{4} \mathrm{H}_{11} \mathrm{O}_{3} \mathrm{~N}$ & 121,14 & General Electric \\
\hline Uréia & $\mathrm{CH}_{4} \mathrm{~N}_{2} \mathrm{O}$ & 60,06 & General Electric \\
\hline $\begin{array}{l}\text { 3-[3-colamidopropil- } \\
\text { dimetilamônio]-1-propano } \\
\text { sulfonato (CHAPS) }\end{array}$ & $\mathrm{C}_{32} \mathrm{H}_{58} \mathrm{~N}_{2} \mathrm{O}_{7} \mathrm{~S}$ & 614,88 & Merck \\
\hline
\end{tabular}




\subsection{QUANTIFICAÇÃO DE MERCÚRIO TOTAL NOS TECIDOS}

A quantificação do mercúrio total nas amostras de tecido muscular dos tucunarés foi feita por meio da técnica de espectrometria de absorção atômica acoplado a sistema de geração de vapor frio de mercúrio (CVAAS), com o equipamento SMS 100 da Perkin Elmer. Para tanto, as amostras de tecido muscular foram descongeladas à temperatura ambiente e transferidos para "barquinhas" de níquel, com quantidade suficiente de terra diatomácea para absorver todo o volume de padrão. Em seguida, foi registrada a massa e iniciaram-se as análises com aproximadamente $0,04 \mathrm{~g}$ de tecido muscular. As quantificações foram feitas em triplicatas (Tabela 6).

Tabela 6 - Condições para construção da curva analítica.

\begin{tabular}{cccc}
\hline Ponto & $\begin{array}{c}\text { Concentração do Padrão } \\
(\mathbf{m g} / \mathbf{L})\end{array}$ & Volume $(\boldsymbol{\mu L})$ & Tempo de Secagem (s) \\
\hline Branco & Água & 100 & 300 \\
\hline $10 \mathrm{ng}$ & 0,1 & 100 & 300 \\
\hline $15 \mathrm{ng}$ & 0,1 & 150 & 450 \\
\hline $20 \mathrm{ng}$ & 0,1 & 200 & 600 \\
\hline $25 \mathrm{ng}$ & 0,1 & 250 & 750 \\
\hline $30 \mathrm{ng}$ & 0,1 & 300 & 900 \\
\hline $100 \mathrm{ng}$ & 1,0 & 100 & 300 \\
\hline $150 \mathrm{ng}$ & 1,0 & 150 & 450 \\
\hline $200 \mathrm{ng}$ & 1,0 & 200 & 600 \\
\hline $250 \mathrm{ng}$ & 1,0 & 250 & 750 \\
\hline $300 \mathrm{ng}$ & 1,0 & 300 & 900
\end{tabular}

\subsection{EXTRAÇÃO DE PROTEÍNAS}

A extração das proteínas foi feita por maceração das amostras com auxílio de almofariz e pistilo. Neste procedimento aproximadamente $1 \mathrm{~g}$ de tecido muscular dos 5 exemplares de tucunarés açú (Cichla temensis) oriundos da primeira coleta no rio Negro foram maceradas juntamente com $5 \mathrm{~mL}$ de água deionizada. Em seguida, os extratos contendo as proteínas foram separados da parte sólida através da centrifugação a 13.000 rpm por 30 min a $4^{\circ} \mathrm{C}$, o sobrenadante foi recolhido e a centrifugação, nas mesmas condições, foi repedida, a fim de obter um extrato proteico livre de interferentes.

Antes da otimização do método de separação de proteínas por 2D-PAGE, as proteínas presentes no extrato foram fracionadas de acordo com a massa molar, sendo uma fração com proteínas maiores (massa molar >50 kDa) e outra com proteínas menores (massa molar <50 kDa). Foram realizados procedimentos em três etapas, a primeira consistiu em transferir $1 \mathrm{~mL}$ de extrato proteico e $1 \mathrm{~mL}$ da solução de clorofórmio e etanol para um frasco do tipo eppendorf ${ }^{\circledR}$, que foi mantido em repouso a 
$10{ }^{\circ} \mathrm{C}$ por 30 min. Logo em seguida, foi feito a centrifugação a $13.000 \mathrm{rpm}$ por $30 \mathrm{~min}$ a $4{ }^{\circ} \mathrm{C}$, o sobrenadante foi recolhido e deixado, novamente em repouso a $10{ }^{\circ} \mathrm{C}$, por 15 min. A amostra foi centrifugada mais uma vez a $13.000 \mathrm{rpm}$ por $30 \mathrm{~min}$ a $4{ }^{\circ} \mathrm{C}$. Na terceira etapa, foi adicionado $400 \mu \mathrm{L}$ da solução de etanol e ácido clorídrico no sobrenadante resultante das duas primeiras etapas, e a solução foi mantida em repouso a $10{ }^{\circ} \mathrm{C}$ por 30 min. Posteriormente, foi realizada uma centrifugação a $13.000 \mathrm{rpm}$ por 30 min a $4{ }^{\circ} \mathrm{C}$ e o sobrenadante foi descartado, resultando no pellet com proteínas de baixa massa molar. Por fim, foram feitas três vezes a solubilização do pellet com $1 \mathrm{~mL}$ de etanol gelado e centrifugação a $10.000 \mathrm{rpm}$ por $5 \mathrm{~min}$ a $4{ }^{\circ} \mathrm{C}$. O pellet foi resultante de todos esses processos foi recolhido para posteriores análises.

\subsection{QUANTIFICAÇÃO DE PROTEÍNAS TOTAIS}

É necessário medir a concentração de proteínas totais no pellet para calcular o volume exato de amostra a ser utilizada na primeira etapa da eletroforese. Assim, foi empregado o método de Biureto, o qual utiliza albumina de soro bovino como padrão (BARNES et al., 1985). A curva analítica foi construída com concentrações de 0 a 100 $\mathrm{g} / \mathrm{L}$ a partir de uma solução estoque de albumina de $100 \mathrm{~g} / \mathrm{L}$. Antes de fazer as leituras das amostras, o pellet foi solubilizado com $100 \mu \mathrm{L}$ de $\mathrm{NaOH}$ 0,50 mol/L. Em seguida, $50 \mu \mathrm{L}$ de amostra solubilizada foi transferida para tubos com $2,5 \mathrm{~mL}$ de reativo de biureto. Foram feitas duplicatas e uma solução "branca", foi usada como padrão, a qual era constituída de $50 \mu \mathrm{L}$ de água ultrapura no lugar da amostra. Os tubos foram levados a banho maria a $32{ }^{\circ} \mathrm{C}$ por $15 \mathrm{~min}$, e posteriormente mantido em repouso à temperatura ambiente por $5 \mathrm{~min}$. As leituras de absorbância foram feitas a $545 \mathrm{~nm}$ por meio de espectrofotômetro UV/Visível.

\subsection{PRIMEIRA ETAPA DO PROCESSO ELETROFORÉTICO}

Depois da quantificação das proteínas pelo método do Biureto, um pellet foi solubilizado com $100 \mu \mathrm{L}$ da solução composta por 2,8 mg de ditiotreitol e $1 \mathrm{~mL}$ da solução contendo uréia $7 \mathrm{~mol} / \mathrm{L}$, tiouréia $2 \mathrm{~mol} / \mathrm{L}$, CHAPS (3-[(3- colaminopropil)dimetilamônio]-1-propano sulfonato) $2 \%(\mathrm{~m} / \mathrm{v})$, anfólitos $0,5 \%(\mathrm{v} / \mathrm{v}) \mathrm{em} \mathrm{pH}$ variando de 3 a 10 e azul de bromofenol $0,002 \%(\mathrm{~m} / \mathrm{v})$. Em seguida, $70 \mu \mathrm{L}$ do precipitado solubilizado, calculado de acordo com o manual do isoeletrofocalizador (IEF), foi aplicada nas fitas de $13 \mathrm{~cm}$ de gel pré-fabricado com anfólitos imobilizados de $\mathrm{pH}$ variando entre 3 e 10 (LIMA et al., 2010). 
Essas fitas foram colocadas na caixa de hidratação IPGBOX, cobertas com óleo mineral e mantidas à temperatura ambiente por aproximadamente $12 \mathrm{~h}$. Após esse período, as fitas foram transferidas para o isoeletrofocalizador EttanTM IPGphorTM 3 para realização da primeira dimensão do processo eletroforético (LIMA et al., 2010; NEVES et al., 2012; SANTOS et al., 2011; SILVA et al., 2013).

A programação utilizada nesta etapa está apresentada na Tabela 7.

Tabela 7 - Programação da focalização isoelétrica (IEF).

\begin{tabular}{ccc}
\hline Fase & Tensão $(\mathbf{V})$ & Acúmulo $(\mathbf{V h})$ \\
\hline 1 & 500 & 500 \\
\hline 2 & 1.000 & 800 \\
\hline 3 & 10.000 & 11300 \\
\hline 4 & 10.000 & 3000 \\
\hline
\end{tabular}

Concluída a IEF, as proteínas presentes na fita foram re-hidratadas uma vez para manterem-se em suas formas reduzidas e, posteriormente, para evitar uma possível reoxidação durante a segunda fase do processo eletroforético. Para tanto se alquilam os grupos tióis das proteínas. Na primeira re-hidratação utilizou-se $5 \mathrm{~mL}$ da solução uréia 6 mol. $L^{-1}$, SDS $2 \%(\mathrm{~m} / \mathrm{v})$, glicerol 30\% (v/v), Tris-HCl 50 mmol.L $\mathrm{L}^{-1}$, azul de bromofenol 0,002\% (m/v) e $50 \mathrm{mg}$ de ditiotreitol. Na segunda re-hidratação, a solução foi similar, contudo, o ditiotreitol foi substituído por $125 \mathrm{mg}$ de iodoacetamida 2,5\% (m/v). Cada etapa durou 15 min sob baixa rotação em mesa agitadora (LIMA et al., 2010; NEVES et al., 2012; SANTOS et al., 2011; SILVA et al., 2013).

\subsection{SEGUNDA ETAPA DO PROCESSO ELETROFORÉTICO}

Após realizar a IEF e o equilíbrio das proteínas, iniciou-se a segunda fase do processo eletroforético, na qual as proteínas são separadas de acordo com suas massas molares em gel de poliacrilamida, denominada dodecil-sulfato de sódio (SDS) de poliacrilamida (PAGE).

Para tanto, placas de vidro com dimensões 180 x $160 \times 1,5 \mathrm{~mm}$ e os suportes da 2D-PAGE foram limpos com etanol e montados.

Foi preparado o gel de poliacrilamida a $15 \%(\mathrm{~m} / \mathrm{v}) \mathrm{com}: 7,5 \mathrm{~g}$ de acrilamida, 200 $\mu \mathrm{g}$ de $\mathrm{N}, \mathrm{N}$ '-metilenobisacrilamida, 1,29 $\mathrm{g}$ de tris-hidroximetil amino metano - $\mathrm{HCl} \mathrm{pH}$ 8,8, $50 \mu \mathrm{g}$ de dodecil sulfato de sódio (SDS), $250 \mu \mathrm{L}$ de persulfato de amônio, 16,5 $\mu \mathrm{L}$ de N,N',N,N'-tetrametilenodiamina (TEMED) e 49,75 mL de água ultrapura. Por fim, a solução foi inserida nas placas e cerca de $2 \mathrm{~h}$ depois o gel estava polimerizado. 
A fita com as proteínas equilibradas e um pequeno papel de filtro com $9 \mu \mathrm{L}$ de padrão de massa molar, composto por $\beta$-fosforilase $(97,0 \mathrm{kDa})$, albumina $(66,0 \mathrm{kDa})$, ovalbumina (45,0 kDa), anidrase carbônica $(30,0 \mathrm{kDa})$, inibidor de tripsina $(20,1 \mathrm{kDa}) \mathrm{e}$ $\alpha$ - lactoalbumina $(14,4 \mathrm{kDa})$, foram inseridos nas placas, bem próximos à parte superior do gel. Ambos foram cobertos por agarose $0,5 \%(\mathrm{~m} / \mathrm{v})$, a qual foi previamente preparada com tris-hidroximetil amino metano, glicina, dodecil sulfato de sódio, água ultrapura, agarose e azul de bromofenol.

Logo em seguida, a placa contendo o gel, a fita e o padrão, conforme descrito anteriormente, e os tampões de corrida da parte superior e inferior da placa foram inseridos na cuba SE 600 Ruby para eletroforese do tipo 2D-PAGE. Esses tampões são soluções que permitem a migração das proteínas através do gel até certo ponto, onde atinge sua massa molar, devido à diferença de potencial. $\mathrm{O}$ tampão de corrida da parte inferior continha 2,7 L de água ultrapura, 6,06 g tris-hidroximetil amino metano, 28,82 $\mathrm{g}$ de glicina e $2 \mathrm{~g}$ de dodecil sulfato de sódio. O tampão de corrida da parte superior é semelhante ao tampão da parte inferior, com exceção do volume de água ultrapura, o qual foi de $800 \mathrm{~mL}$.

Com todo o sistema para eletroforese 2D-PAGE preparado, a corrida eletroforética foi efetuada com a tensão fixa nas duas etapas, conforme apresentado abaixo (Tabela 8).

Tabela 8 - Programação da corrida eletroforética em segunda dimensão.

\begin{tabular}{ccccc}
\hline Etapa & Tensão $(\mathbf{V})$ & Microamperagem $(\mathbf{m A})$ & Corrente $(\mathbf{W})$ & Tempo (minutos) \\
\hline 1 & 100 & 200 & 100 & 30 \\
\hline 2 & 160 & 200 & 100 & 390 \\
\hline
\end{tabular}

Terminadas essas etapas, o gel foi removido cuidadosamente das placas e colocado em mesa agitadora a $40 \mathrm{rpm}$ durante $1 \mathrm{~h}$ numa solução fixadora $(25 \mathrm{~mL}$ de ácido acético, $100 \mathrm{~mL}$ de etanol e $125 \mathrm{~mL}$ de água ultrapura). O fixador foi descartado e o corante foi adicionado, o qual consistia na solução de sulfato de amônio $8 \%(\mathrm{~m} / \mathrm{v})$, ácido fosfórico 1,6\% (v/v), azul de coomassie G-250 0,08\% (m/v) e metanol 25\% (v/v). O corante ficou em contato com o gel durante $72 \mathrm{~h}$ em mesa agitadora a $40 \mathrm{rpm}$ e depois foi removido através de sucessivas lavagens com água ultrapura até que as proteínas (spots) ficassem visíveis (LIMA et al., 2010; NEVES et al., 2012; SANTOS et al., 2011; SILVA et al., 2013). 


\subsection{TRATAMENTO DAS IMAGENS}

O gel foi escaneado em Scanner GE Healthcare, em seguida, por meio do programa ImageMaster platinum 7.0. a imagem foi editada para remoção de falsos spots e obtenção de dados como o número de spots por gel, pI, massa molar e volume dos spots (GE HEALTHCARE, 2007).

Foram seguidas as recomendações do fabricante GE Healthcare para obtenção das imagens dos géis. A resolução escolhida foi de 300 dpi, o zoom foi de $100 \%$ e o depth, o qual regula o nível de cinza do pixel, foi 12 ou 16 bits por pixel.

Uma pequena região do gel onde continham spots de expressão intermediária foi selecionada. Neles aplicaram-se o smooth 3, que é o número de vezes que o programa homogeneíza a região selecionada antes de seguir a detecção; o saliency 30, baseia-se na curvatura do spot, separa os spots reais e; min area 5, o qual remove as regiões menores que as indicadas. Esses parâmetros foram estendidos para todos os spots do gel através de uma ferramenta de detecção automática.

Por meio da equivalência na distribuição, volume, intensidade relativa, ponto isoelétrico (pI) e massa molar (MM) entre os spots dos dois géis (matching) obteve-se a correlação entre os géis, os quais, posteriormente, foram recortados com ponteira de pipeta e, cada spot igual, foi analisado como uma possível proteína.

\subsection{QUANTIFICAÇÃO DO MERCÚRIO NOS TECIDOS, PRECIPITADOS E SPOTS PROTEICOS}

Em todas as etapas da 2D-PAGE utiliza-se o pool (conjunto) das amostras de tecido muscular. Assim, a concentração de mercúrio total apenas dos tucunarés de uma localidade, da mesma subespécie e que apresentaram o maior teor de mercúrio, o qual foi determinado anteriormente por CVAAS, foi quantificada novamente por meio da técnica espectrometria de absorção atômica em forno de grafite (GFAAS).

Além do pool das amostras de tecido muscular, os precipitados de maior e menor massa molar e os spots proteicos também foram submetidos à técnica GFAAS para quantificação do mercúrio total.

No preparo das amostras, cerca de $100 \mathrm{mg}$ de tecido muscular, quatro repetições dos spots proteicos e a massa total dos pellets proteicos de cada uma das duas etapas da precipitação fracionada (proteínas $>50 \mathrm{kDa}$ e $<50 \mathrm{kDa}$ ) foram inseridos em frascos de digestão (procedimento feito em duplicata). Em cada frasco foram transferidas alíquotas de $0,50 \mathrm{~mL}$ de ácido sulfúrico concentrado e $0,25 \mathrm{~mL}$ de peróxido de hidrogênio $30 \%$ 
(m/m). Logo em seguida, permaneceram em banho de ultrassom à temperatura de $40{ }^{\circ} \mathrm{C}$ e 135 Watts de potência até que todas as amostras estivessem digeridas. Os extratos ácidos resultantes desses processos foram transferidos para balões volumétricos, onde o volume foi completado para $5 \mathrm{~mL}$ com água ultrapura. Para validação do método de mineralização foi utilizado padrão certificado Fish Protein DORM 4 NRC contendo $410 \pm 55 \mu \mathrm{g} \mathrm{kg}^{-1}$ de mercúrio total (MORAES et al., 2013b; BRAGA et al., 2014).

$\mathrm{Na}$ determinação de mercúrio total foi utilizado espectrômetro de absorção atômica SHIMADZU modelo AA-6800, equipado com corretor de absorção de fundo com lâmpada de deutério e sistema self-reverse, tubo de grafite pirolítico com plataforma integrada e amostrador automático ASC-6100. Foi utilizada lâmpada de cátodo oco de mercúrio SHIMADZU, operada com corrente mínima de $12 \mathrm{~mA}$ e corrente máxima de $400 \mathrm{~mA}$ (corrente utilizada na correção de fundo - BG). O comprimento de onda utilizado foi de $253,7 \mathrm{~nm}$ e resolução espectral de $0,5 \mathrm{~nm}$. Argônio foi utilizado como gás inerte, mantendo-se um fluxo constante de $1 \mathrm{~L} \mathrm{~min}^{-1}$ durante todo o programa de aquecimento, exceto na etapa de atomização, na qual o fluxo de gás foi interrompido. Os sinais de absorbância foram medidos em área de pico.

\subsection{ANÁLISES ESTATÍSTICAS}

Antes de selecionar o teste estatístico mais apropriado para qualquer tipo de estudo, é necessário que algumas características do conjunto de dados sejam analisadas, como o tipo de variável (quantitativa ou qualitativa), a situação da variação entre os grupos a serem comparados (homogênea ou heterogênea), o número de grupos e se os mesmos são dependentes ou independentes (WAGNER, 1998).

Existem duas classes de testes estatísticos, os paramétricos que normalmente são aplicados em variáveis quantitativas, as quais possuem uma distribuição dos dados homogênea; e os não-paramétricos mais apropriados para variáveis qualitativas, ou aquelas quantitativas que não preencham os requisitos dos testes paramétricos como a presença de outliers no conjunto de dados, isto é, valores muito acima da média dos dados (WAGNER, 1998).

Ainda segundo o mesmo autor, geralmente em testes não-paramétricos os dados são classificados em posições (ranks) e comparados sem ser necessário um padrão específico de distribuição, por isso, são denominados também como testes de distribuição livre. 
O conjunto de dados deste estudo é heterogêneo e há alguns outliers, além de estarem em medidas de grandeza diferentes. Por estas razões a Correlação de Spearman, a qual é um teste não-paramétrico, foi selecionada para comparar as variáveis: concentrações de mercúrio total e comprimento dos tucunarés.

O coeficiente de Spearman, representado pela letra $\mathbf{r}$ é utilizado para verificar se as variáveis estão associadas e qual o seu grau de associação (GUIMARÃES, 2008).

$\mathrm{O}$ resultado foi definido como estatisticamente significativo quando o $\mathbf{p}$ fosse menor que 0,05. Caso o coeficiente da Correlação de Spearman fosse alto, a hipótese seria que quanto maior o comprimento do tucunaré, maior seria sua idade e, consequentemente, maior seria o tempo de exposição ao mercúrio. Se o coeficiente da Correlação de Spearman fosse baixo, indicaria que as variáveis são independentes, que não há uma relação significativa de causa e efeito.

Já a estatística descritiva foi utilizada para apresentar características gerais (comprimento, peso e concentração de mercúrio total) dos tucunarés por local de amostragem.

Gráficos do tipo boxplot foram elaborados para analisar as concentrações de mercúrio total e a massa total de mercúrio nos tucunarés por locais de amostragem. Por meio deste tipo de gráfico é possível avaliar pela média e pela variância dos dados quais localidades possuem tucunarés com maiores níveis de mercúrio em seus tecidos.

Todas as análises estatísticas foram realizadas no software Statistica, versão 7.1 (StatSoft, Inc. 2005), com exceção do gráfico de dispersão que foi elaborado no programa Excel.

\subsection{LICENÇA DE COLETA E TRANSPORTE DE AMOSTRAS BIOLÓGICAS}

A proposta de estudo foi enviada no início do ano de 2013 ao Sistema de Autorização e Informação em Biodiversidade - SISBIO para aquisição da licença de coleta e transporte de amostras biológicas. Essa autorização foi expedida com base na Instrução Normativa nº 154/2007, por meio do código de autenticação 78317179 , resultando na emissão da Licença $\mathrm{N}^{\circ}$ 40791-1 (autorização para atividades com finalidade científica) com validade entre 05 de setembro de 2013 a 05 de outubro de 2014. Após o término desse prazo, a licença foi renovada com validade até 06 de setembro de 2015 (Anexo 1). 


\section{RESULTADOS}

Os dados biométricos (comprimento e peso totais) e as concentrações de mercúrio total dos tucunarés coletados nos rios Negro, Apuaú, Solimões, Purus e Madeira e nos reservatórios das usinas hidrelétricas de Balbina (rio Uatumã), Cana Brava (rio Tocantins) e Tucuruí (rio Tocantins) estão apresentados na Tabela 9.

Tabela 9 - Comprimento, peso e concentrações de mercúrio totais em amostras de várias subespécies de tucunarés capturados nos rios Negro, Apuaú, Solimões, Purus e Madeira, e reservatórios das usinas hidrelétricas Balbina, Cana Brava e Tucuruí.

\begin{tabular}{|c|c|c|c|c|}
\hline Localização & Subespécie & $\begin{array}{l}\text { Comprimento } \\
\text { total }(\mathrm{cm})\end{array}$ & $\begin{array}{c}\text { Peso } \\
\text { total }(g)\end{array}$ & $\begin{array}{c}\text { Concentração de } \mathbf{H g} \\
(\mathrm{mg} / \mathrm{kg})\end{array}$ \\
\hline \multirow{6}{*}{$\begin{array}{c}\text { Rio Negro, Manaus - } \\
\text { AM } \\
\left(1^{\mathrm{a}} \text { coleta }\right)\end{array}$} & $\begin{array}{l}\text { Tucunaré Pitanga } \\
\text { (Cichla kelberi) }\end{array}$ & 35 & 650 & 0,513 \\
\hline & \multirow{5}{*}{$\begin{array}{l}\text { Tucunaré Açú } \\
\text { (Cichla temensis) }\end{array}$} & 45 & 1.170 & 4,468 \\
\hline & & 45 & 1.100 & 0,717 \\
\hline & & 48 & 1.500 & 0,459 \\
\hline & & 53 & 1.900 & 0,279 \\
\hline & & 74 & 5.900 & 1,885 \\
\hline \multirow{5}{*}{$\begin{array}{c}\text { Rio Negro, Manaus - } \\
\text { AM } \\
\left(2^{\mathrm{a}} \text { coleta }\right)\end{array}$} & \multirow{3}{*}{$\begin{array}{c}\text { Tucunaré Paca } \\
\text { (Cichla temensis paca) }\end{array}$} & 43 & 950 & 1,330 \\
\hline & & 60 & 2.200 & 1,156 \\
\hline & & 51 & 1.610 & 0,985 \\
\hline & $\begin{array}{l}\text { Tucunaré Borboleta } \\
\text { (Cichla orinocensis) }\end{array}$ & 40 & 770 & 1,005 \\
\hline & $\begin{array}{c}\text { Tucunaré Açú } \\
\text { (Cichla temensis) }\end{array}$ & 70 & 5.100 & 0,836 \\
\hline \multirow{6}{*}{$\begin{array}{c}\text { Rio Apuaú, Novo Airão } \\
- \text { AM }\end{array}$} & $\begin{array}{l}\text { Tucunaré Açú } \\
\text { (Cichla temensis) }\end{array}$ & 68 & 4.000 & 0,977 \\
\hline & \multirow{2}{*}{$\begin{array}{l}\text { Tucunaré Borboleta } \\
\text { (Cichla orinocensis) }\end{array}$} & 39 & 600 & 0,486 \\
\hline & & 43 & 850 & 1,392 \\
\hline & \multirow{3}{*}{$\begin{array}{c}\text { Tucunaré Paca } \\
\text { (Cichla temensis paca) }\end{array}$} & 51 & 1.450 & 0,939 \\
\hline & & 50 & 1.200 & 0,769 \\
\hline & & 65 & 3.000 & 0,918 \\
\hline \multirow{5}{*}{$\begin{array}{c}\text { Rio Solimões, Coari - } \\
\text { AM }\end{array}$} & \multirow{5}{*}{$\begin{array}{l}\text { Tucunaré Amarelo } \\
\text { (Cichla ocellaris) }\end{array}$} & 40 & 1.025 & 1,159 \\
\hline & & 39 & 905 & 1,248 \\
\hline & & 39 & 930 & 0,454 \\
\hline & & 38 & 870 & 0,355 \\
\hline & & 38 & 930 & 1,454 \\
\hline \multirow{5}{*}{$\begin{array}{l}\text { Rio Solimões, Codajás } \\
\text { - AM }\end{array}$} & \multirow{5}{*}{$\begin{array}{l}\text { Tucunaré Amarelo } \\
\text { (Cichla ocellaris) }\end{array}$} & 42 & 990 & 1,088 \\
\hline & & 41 & 945 & 0,859 \\
\hline & & 40 & 900 & 1,345 \\
\hline & & 41 & 980 & 1,053 \\
\hline & & 45 & 1.200 & 1,731 \\
\hline
\end{tabular}


Tabela 9 - Comprimento, peso e concentrações de mercúrio totais em amostras de várias subespécies de tucunarés capturados nos rios Negro, Apuaú, Solimões, Purus e Madeira, e reservatórios das usinas hidrelétricas Balbina, Cana Brava e Tucuruí_continuação.

\begin{tabular}{|c|c|c|c|c|}
\hline Localização & Subespécie & $\begin{array}{c}\text { Comprimento } \\
\text { total }(\mathrm{cm})\end{array}$ & $\begin{array}{c}\text { Peso } \\
\text { total }(g)\end{array}$ & $\begin{array}{c}\text { Concentração de } \mathbf{H g} \\
(\mathrm{mg} / \mathrm{kg})\end{array}$ \\
\hline \multirow{6}{*}{ Rio Purus - AM } & \multirow{6}{*}{$\begin{array}{l}\text { Tucunaré Amarelo } \\
\text { (Cichla pleiozona) }\end{array}$} & 39 & 795 & 0,569 \\
\hline & & 37 & 755 & 0,495 \\
\hline & & 38 & 745 & 0,546 \\
\hline & & 38 & 775 & 0,546 \\
\hline & & 39 & 830 & 0,719 \\
\hline & & 37 & 720 & 0,891 \\
\hline \multirow{6}{*}{$\begin{array}{l}\text { Rio Madeira, Porto } \\
\text { Velho - RO }\end{array}$} & \multirow{6}{*}{$\begin{array}{l}\text { Tucunaré Amarelo } \\
\text { (Cichla pleiozona) }\end{array}$} & 38 & 1.090 & 0,613 \\
\hline & & 35 & 738 & 0,376 \\
\hline & & 35 & 736 & 0,251 \\
\hline & & 34 & 698 & 0,523 \\
\hline & & 35 & 742 & 0,500 \\
\hline & & 34 & 656 & 0,253 \\
\hline \multirow{6}{*}{$\begin{array}{c}\text { Rio Uatumã - AM } \\
\text { (Reservatório da UHE } \\
\text { Balbina) }\end{array}$} & \multirow{6}{*}{$\begin{array}{c}\text { Tucunaré Açú } \\
\text { (Cichla vazzoleri) }\end{array}$} & 43 & 1.150 & 0,475 \\
\hline & & 43 & 1.250 & 0,363 \\
\hline & & 43 & 1.320 & 0,754 \\
\hline & & 46 & 1.300 & 0,277 \\
\hline & & 46 & 1.450 & 0,226 \\
\hline & & 46 & 1.450 & 0,237 \\
\hline \multirow{6}{*}{$\begin{array}{c}\text { Rio Tocantins - GO } \\
\text { (Reservatório da UHE } \\
\text { Cana Brava) }\end{array}$} & \multirow{6}{*}{$\begin{array}{l}\text { Tucunaré Azul } \\
\text { (Cichla piquiti) }\end{array}$} & 47 & 3.000 & 0,267 \\
\hline & & 35 & 1.100 & 0,597 \\
\hline & & 43 & 1.500 & 0,286 \\
\hline & & 40 & 1.500 & 0,088 \\
\hline & & 39 & 1.100 & 0,161 \\
\hline & & 30 & 1.000 & 0,162 \\
\hline \multirow{7}{*}{$\begin{array}{c}\text { Rio Tocantins - PA } \\
\text { (Reservatório da UHE } \\
\text { Tucuruí) }\end{array}$} & \multirow{7}{*}{$\begin{array}{c}\text { Tucunaré Paca } \\
\text { (Cichla temensis paca) }\end{array}$} & 36 & 650 & 0,872 \\
\hline & & 37 & 750 & 0,962 \\
\hline & & 36 & 600 & 1,123 \\
\hline & & 36 & 800 & 0,194 \\
\hline & & 35 & 700 & 0,924 \\
\hline & & 33 & 550 & 0,229 \\
\hline & & 34 & 550 & 0,612 \\
\hline
\end{tabular}

O valor médio de comprimento total dos tucunarés amostrados no rio Negro foi $51,3 \pm 12,2 \mathrm{~cm}$, variando de 35 a $74 \mathrm{~cm}$; no rio Apuaú a média foi 52,7 \pm 11,6 cm, variando de 39 a $68 \mathrm{~cm}$; nos tucunarés do rio Solimões o valor médio foi 40,3 $\pm 2,1 \mathrm{~cm}$, variando de 38 a $45 \mathrm{~cm}$; nos tucunarés do rio Purus o valor médio foi $38,0 \pm 0,9 \mathrm{~cm}$, variando de 37 a $39 \mathrm{~cm}$; no rio Madeira a média de comprimento total foi 35,2 \pm 1,5 cm, variando de 34 a $38 \mathrm{~cm}$; nos tucunarés do reservatório de Balbina, construído no rio Uatumã, o valor médio do comprimento dos tucunarés foi 44,5 $\pm 1,6 \mathrm{~cm}$, variando de 43 
a $46 \mathrm{~cm}$; no reservatório de Cana Brava, instalado no rio Tocantins, apresentou o valor médio de 39,0 $\pm 6,0 \mathrm{~cm}$, variando de 30 a $47 \mathrm{~cm}$; já os tucunarés do reservatório de Tucuruí, também localizado no rio Tocantins, o valor médio do comprimento dos tucunarés foi $35,3 \pm 1,4 \mathrm{~cm}$, variando de 33 a $37 \mathrm{~cm}$.

A Figura 9 apresenta os valores médios e a variação entre os comprimentos totais dos tucunarés de acordo com os locais de amostragem. É possível inferir que os maiores comprimento são dos tucunarés oriundos do rio Negro. Além disso, todos os tucunarés deste estudo estão em estágio de maturação, visto que, esta fase ocorre quando a espécie atinge o comprimento entre 20 e 35 cm (KEHRIG et al., 2008).

Figura 9 - Variação do comprimento total dos tucunarés coletados nos rios Negro, Apuaú, Solimões, Purus e Madeira, e nos reservatórios das usinas hidrelétricas Balbina, Cana Brava e Tucuruí.

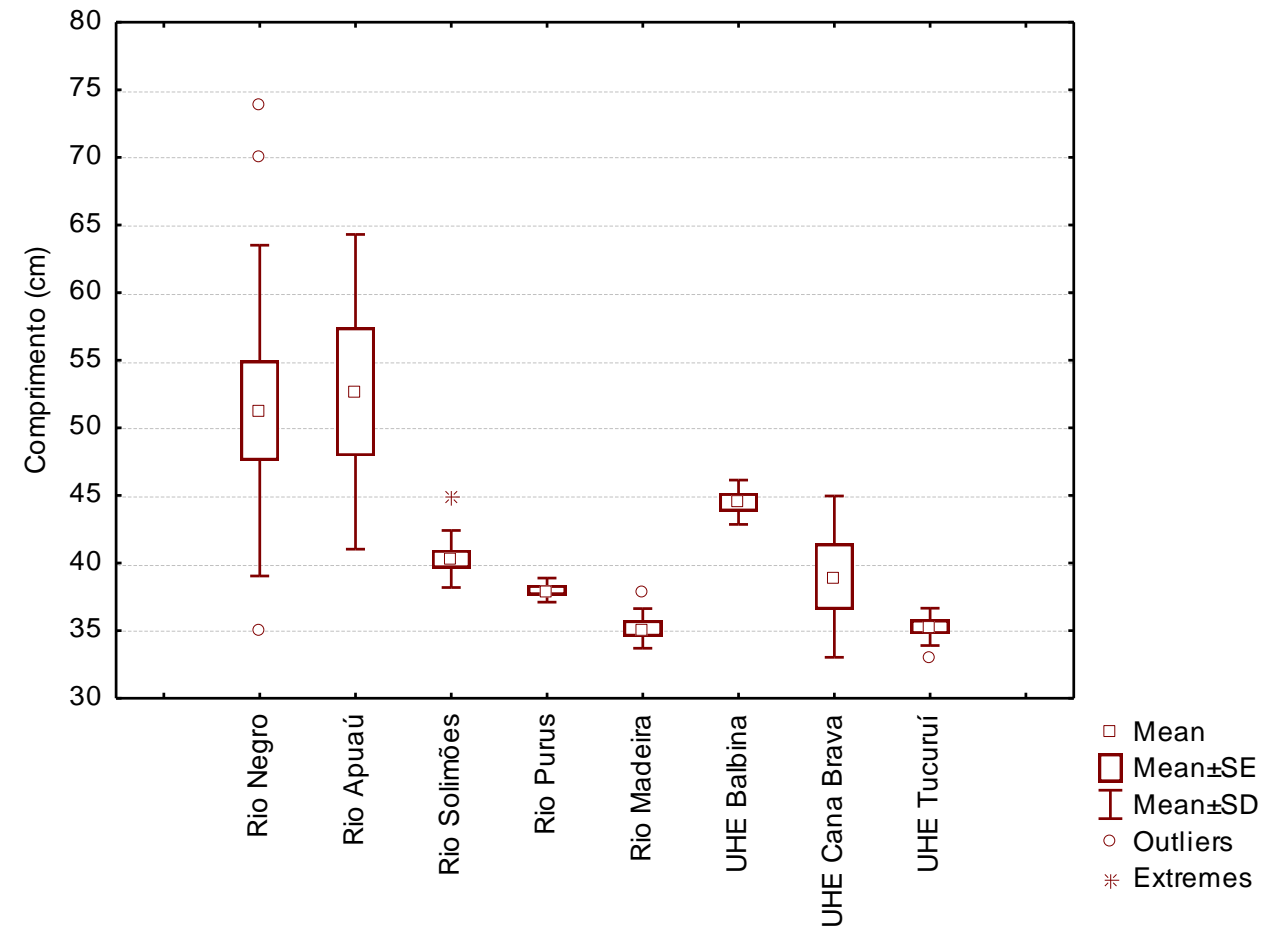

O valor médio de peso total dos tucunarés amostrados no rio Negro foi $2.077 \pm$ $1.764,7 \mathrm{~g}$, variando de 650 a $5.900 \mathrm{~g}$; no rio Apuaú a média foi $1.850 \pm 1.348,3 \mathrm{~g}$, variando de 600 a $4.000 \mathrm{~g}$; nos tucunarés do rio Solimões o valor médio foi $968 \pm$ 93,9 g, variando de 870 a $1.200 \mathrm{~g}$; o valor médio para os tucunarés do rio Purus foi $770 \pm$ $39,0 \mathrm{~g}$, variando de 720 a $830 \mathrm{~g}$; nos tucunarés do rio Madeira a média de peso foi $777 \pm$ 157,0 g, variando de 656 a 1.090 g; no reservatório de Balbina, construído no rio Uatumã, o valor médio do peso dos tucunarés foi $1.320 \pm 116,6 \mathrm{~g}$, variando de $1.150 \mathrm{a}$ 
$1.450 \mathrm{~g}$; os tucunarés do reservatório de Cana Brava, instalado no rio Tocantins, apresentou o valor médio de $1.533 \pm 750,1 \mathrm{~g}$, variando de 1.000 a 3.000 g; já no reservatório de Tucuruí, também localizado no rio Tocantins, o valor médio do peso dos tucunarés foi $657 \pm 97,6 \mathrm{~g}$, variando de 550 a $800 \mathrm{~g}$.

A Figura 10 apresenta os valores médios e a variação entre os pesos totais dos tucunarés de acordo com os locais de amostragem, sendo os maiores pesos encontrados em tucunaré do rio Negro.

Figura 10 - Variação do peso total dos tucunarés coletados nos rios Negro, Apuaú, Solimões, Purus e Madeira, e nos reservatórios das usinas hidrelétricas Balbina, Cana Brava e Tucuruí.

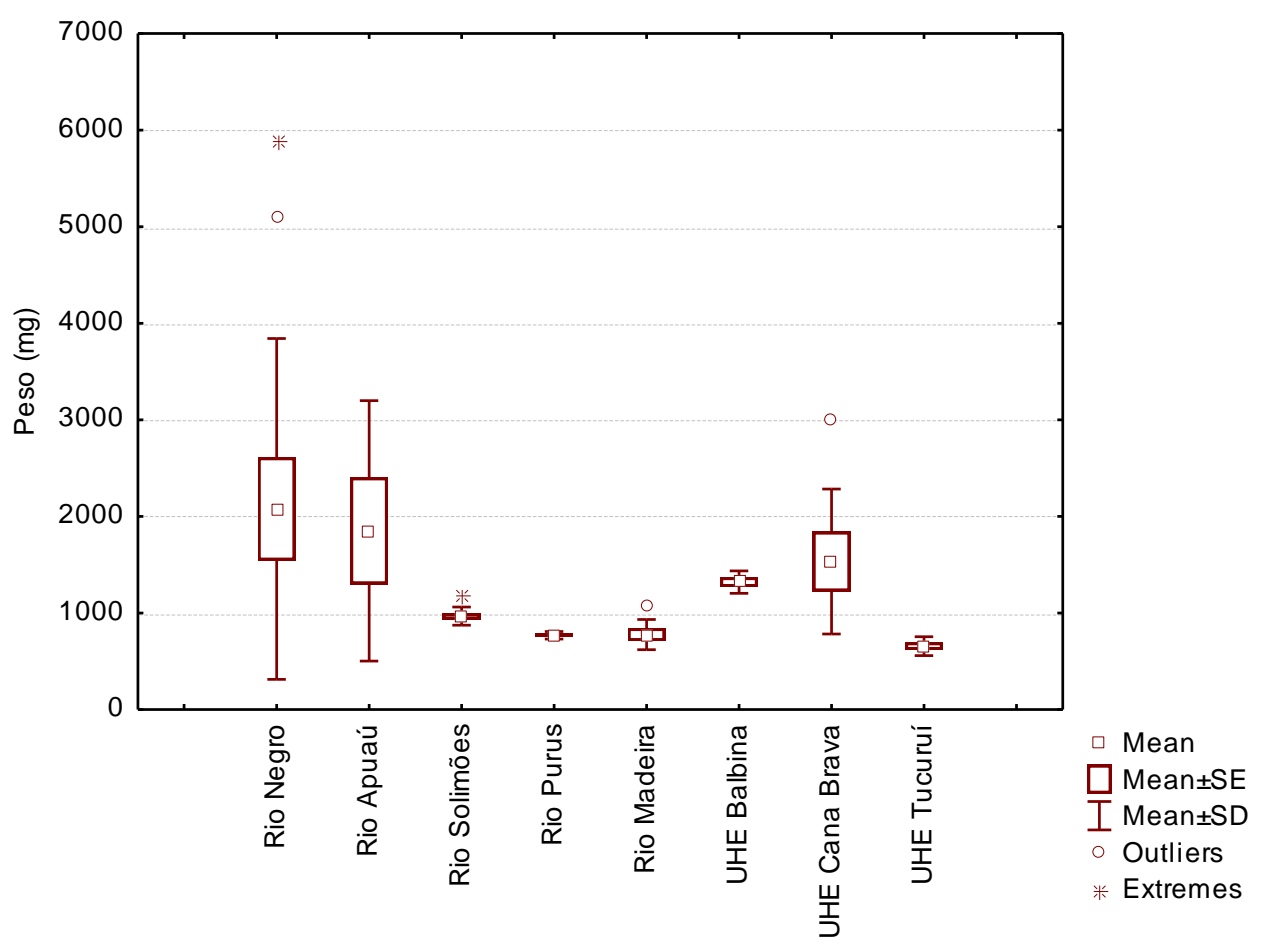

A concentração média de mercúrio total nos tucunarés amostrados no rio Negro foi $1,24 \pm 1,16 \mathrm{mg} / \mathrm{kg}$, variando de 0,28 a $4,47 \mathrm{mg} / \mathrm{kg}$; no rio Apuaú foi $0,91 \pm 0,3$ $\mathrm{mg} / \mathrm{kg}$, variando de 0,49 a $1,39 \mathrm{mg} / \mathrm{kg}$; nos tucunarés do rio Solimões concentração média foi $1,07 \pm 0,43 \mathrm{mg} / \mathrm{kg}$, variando de 0,36 a $1,73 \mathrm{mg} / \mathrm{kg}$; nos tucunarés do rio Purus a concentração média foi $0,63 \pm 0,15 \mathrm{mg} / \mathrm{kg}$, variando de 0,50 a $0,89 \mathrm{mg} / \mathrm{kg}$; nos tucunarés do rio Madeira a concentração média de mercúrio total foi $0,42 \pm 0,15 \mathrm{mg} / \mathrm{kg}$, variando de 0,25 a $0,61 \mathrm{mg} / \mathrm{kg}$;

no reservatório de Balbina, construído no rio Uatumã, o valor médio do mercúrio total dos tucunarés foi $0,39 \pm 0,20 \mathrm{mg} / \mathrm{kg}$, variando de 0,23 a $0,75 \mathrm{mg} / \mathrm{kg}$; os tucunarés do reservatório de Cana Brava, instalado no rio Tocantins, apresentou o valor médio de 
$0,26 \pm 0,18 \mathrm{mg} / \mathrm{kg}$, variando de 0,09 a $0,60 \mathrm{mg} / \mathrm{kg}$; já no reservatório de Tucuruí, também localizado no rio Tocantins, o valor médio do mercúrio total dos tucunarés foi $0,70 \pm 0,37 \mathrm{mg} / \mathrm{kg}$, variando de 0,19 a $1,12 \mathrm{mg} / \mathrm{kg}$.

As concentração média de mercúrio total nos tucunarés amostrados em regiões classificadas como águas escuras (rios Apuaú e Negro) foi de 1,12 \pm 0,95 mg/kg, variando de 0,28 a $4,47 \mathrm{mg} / \mathrm{kg}$, enquanto que nos tucunarés amostrados em rios pertencentes à classe de águas brancas (rios Solimões, Purus e Madeira) a concentração de mercúrio total foi de $0,77 \pm 0,42 \mathrm{mg} / \mathrm{kg}$, variando de 0,25 a $1,73 \mathrm{mg} / \mathrm{kg}$. Já os reservatórios (Balbina, Cana Brava e Tucuruí) apresentaram as menores concentrações de mercúrio, sendo o valor médio de 0,46 \pm 0,32 mg/kg, variando de 0,09 a 1,12 mg/kg.

A Figura 11 apresenta a média e a variação entre as concentrações de mercúrio total de cada localidade. A linha vermelha no gráfico representa o limite máximo determinado pela legislação brasileira quanto às concentrações de mercúrio em peixes predadores. Nota-se que muitos valores ultrapassaram as concentrações estipuladas, o que é muito preocupante devido ao caráter acumulativo desse metal. As concentrações aumentam na sequência: reservatório da UHE Cana Brava < reservatório da UHE Balbina < rio Madeira < rio Purus < reservatório da UHE Tucuruí < rio Apuaú < rio Solimões < rio Negro.

As concentrações de mercúrio podem variar em função das características dos ambientes. Segundo Amorim et al. (2000) e Roulet et al. (1998) os reservatórios artificiais podem potencializar a metilação do mercúrio por serem ambientes lênticos. Entretanto, neste estudo a média e a variação das concentrações de mercúrio em função dos tipos de ambientes apresentada na Figura 11, mostrou que os tucunarés coletados em rios apresentam as maiores concentrações médias de mercúrio quando comparados aos tucunarés dos reservatórios, com exceção do reservatório da UHE Tucuruí, que possui concentrações superiores às dos rios Madeira e Purus. 
Figura 11 - Variação das concentrações de mercúrio total quantificadas no tecido muscular de tucunarés coletados nos rios Negro, Apuaú, Solimões, Purus e Madeira, e nos reservatórios das usinas hidrelétricas Balbina, Cana Brava e Tucuruí.

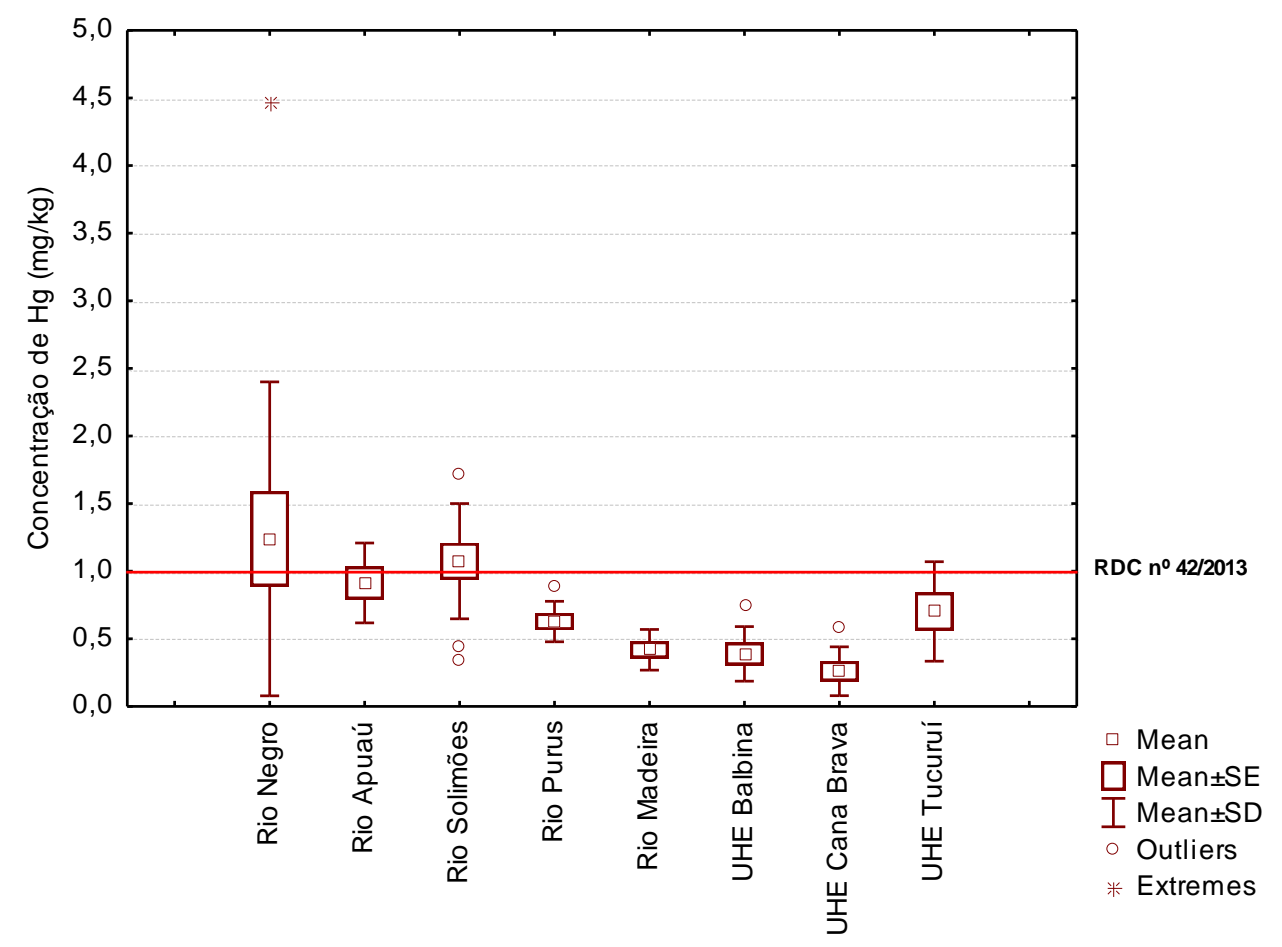

Um gráfico foi elaborado para representar a distribuição da massa total de mercúrio em função do comprimento do exemplar de peixe, considerando os diferentes locais de amostragem. O comprimento foi selecionado por representar o tempo de vida de cada peixe e consequentemente o tempo de exposição do mercúrio (Figura 12).

A distribuição da massa de mercúrio total em função do comprimento aumentam na sequência: rio Madeira < reservatório da UHE Cana Brava < reservatório da UHE Balbina < rio Purus < reservatório da UHE Tucuruí < rio Solimões < rio Apuaú < rio Negro. Considerando as características físico-químicas de cada ambiente, os ambientes de águas escuras possuem as maiores massas de mercúrio neste estudo. 
Figura 12 - Variação da massa de mercúrio total em função dos locais de amostragem (rios Negro, Apuaú, Solimões, Purus e Madeira, e reservatórios das usinas hidrelétricas Balbina, Cana Brava e Tucuruí).

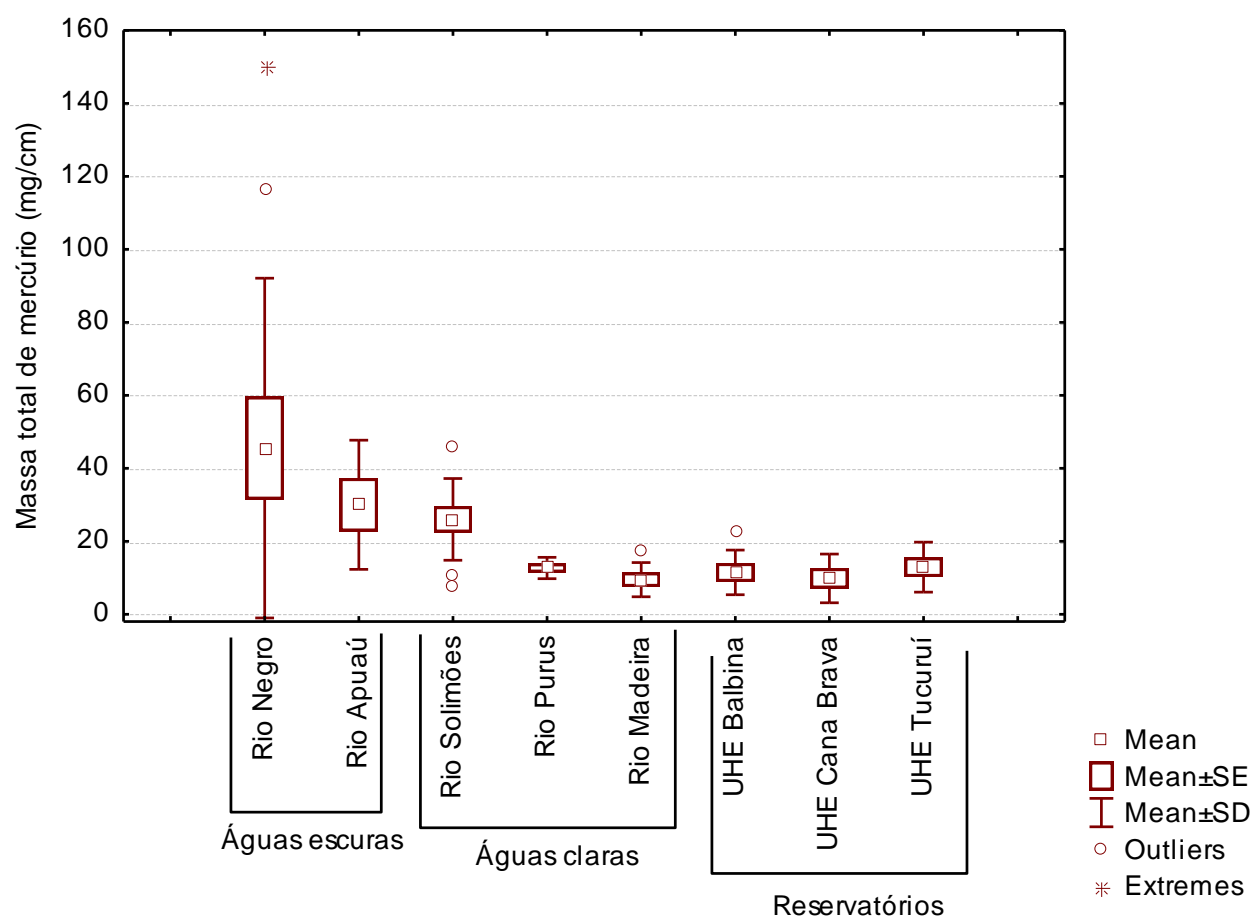

Conforme pode ser observado na Tabela 9 e nas Figuras 11 e 12 não há homogeneidade nas variâncias das concentrações de mercúrio e nem dos comprimentos. Sendo assim, buscou-se avaliar o grau de correlação entre essas variáveis por meio do teste não-paramétrico Correlação de Spearman.

A variável peso não foi correlacionada com as concentrações de mercúrio, pois é uma medida muito influenciada por algumas variações, como a disponibilidade de alimento e os fenômenos fisiológicos temporais de cada subespécie. Já o comprimento não é influenciado por qualquer fator, por isso é o mais indicado para ser correlacionado com as concentrações de mercúrio total.

O teste foi realizado com as 58 amostras e em seguida separando-as em classes distintas (águas escuras, águas claras e reservatórios). O teste foi significativo considerando todas as amostras e a classe de águas claras, sendo o valor de alfa adotado para o nível de significância de 0,05 (5\%). O coeficiente de correlação entre as concentrações de mercúrio total e os comprimentos considerando os 58 tucunarés foi baixo (0,276997). Já com as amostras de águas claras o coeficiente foi elevado (0,715998), mostrando que possivelmente há correlação entre o comprimento, o qual 
está associado ao tempo de vida do espécime, com as concentrações de mercúrio desses tucunarés (Tabela 10).

Tabela 10 - Correlação de Spearman com as variáveis comprimento e concentração de mercúrio total dos tucunarés de todos os locais de amostragem e de classes (águas escuras, águas claras e reservatórios).

\begin{tabular}{ccccc}
\hline & Valid & Spearman & $\mathbf{t}(\mathbf{N}-2)$ & p-level \\
\hline Todos & 58 & 0,276997 & 2,157271 & 0,035291 \\
\hline Águas escuras & 17 & 0,121547 & 0,474267 & 0,642140 \\
\hline Águas claras & 22 & 0,715998 & 4,586774 & 0,000179 \\
\hline Reservatórios & 19 & $-0,150381$ & $-0,627170$ & 0,538881 \\
\hline
\end{tabular}

Como as maiores concentrações de mercúrio total foram quantificadas na musculatura dos tucunarés oriundos do rio Negro, nesses peixes existe uma maior probabilidade de identificação de proteínas associadas ao mercúrio.

Dessa forma, cinco amostras de tucunarés coletados no rio Negro em março de 2014 foram selecionadas para o fracionamento de proteínas em gel de poliacrilamida (2D-PAGE). Todas as amostras eram da mesma subespécie (Cichla temensis), pois se acredita que as proteínas de subespécies diferentes não sejam todas idênticas.

Como a técnica 2D-PAGE é realizada com o pool (conjunto) das amostras, a concentração de mercúrio total foi quantificada novamente no pool dos cinco tucunarés por meio da técnica espectrometria de absorção atômica em forno de grafite (GFAAS). A determinação da concentração de mercúrio no pool foi feita em duplicata e a média foi de $1,17 \pm 0,035 \mathrm{mg} / \mathrm{kg}$.

Considerando a concentração obtida do pool das amostras, foram feitos oito testes a fim de obter um gel com boa separação das proteínas. Vários fatores foram alterados a cada teste, inicialmente, aplicou-se no gel de poliacrilamida o extrato obtido apenas por centrifugação. O resultado não foi satisfatório, pois além de proteínas, lipídeos, fibras e outras partículas sólidas também estavam presentes no extrato.

Optou-se, então, por precipitar as proteínas presentes no extrato. Testes foram feitos com a precipitação de todas as proteínas, utilizando acetona a $80 \%$ como solvente e, em seguida, com a precipitação fracionada em três etapas. As duas primeiras etapas selecionaram as proteínas $>50 \mathrm{kDa}$ e a terceira etapa agrupou as proteínas $<50 \mathrm{kDa}$, formando um precipitado (pellet). O teste com a precipitação fracionada apresentou os melhores resultados.

É importante ressaltar que, inicialmente, a concentração total de proteínas foi determinada nos extratos obtidos a partir da solubilização dos precipitados utilizando-se o método do Biureto (SYKES et al., 1987). Em seguida, foi aplicada nas fitas uma 
quantidade de massa proteica e soluções previamente calculadas com base no manual do sistema IEF, o qual indica as condições para favorecer uma melhor separação das proteínas (BERKLMAN \& STENSTEDT, 1998).

O tamanho da malha do gel também foi testado, sendo que as concentrações de acrilamida e bis-acrilamida que determinam a quantidade de ligações cruzadas que formam o gel (BRACHT et al., 2003). Foram feitos testes com géis menos e mais porosos, 15 e $12,5 \%(\mathrm{~m} / \mathrm{v})$, respectivamente.

Com as condições usualmente utilizadas para separação das proteínas em segunda dimensão, as proteínas com menor massa molar (abaixo de 14,4 kDa) foram eliminadas do gel a $12,5 \%(\mathrm{~m} / \mathrm{v})$, e mantidas no gel a $15 \%(\mathrm{~m} / \mathrm{v})$.

Dessa forma, o teste que apresentou melhor separação de proteínas foi obtido por meio da precipitação fracionada em gel a $15 \%(\mathrm{~m} / \mathrm{v})$. A quantidade média de proteínas presentes no precipitado (pellet) foi 5,349 $\mu \mathrm{g}$ e o volume aplicado na fita de IEF de precipitado já solubilizado com o tampão da amostra foi de $70 \mu \mathrm{L}$.

A Figura 13 representa a imagem do gel obtido sob as condições descritas, cada círculo vermelho representa uma possível proteína (spot), a qual foi separada de acordo com o seu ponto isoelétrico $(\mathrm{pI})$ que varia de 3 a 10, e com sua massa molar que varia de 14,4 a 97 kDa. 
Figura 13 - Gel a 15\% obtido por 2D-PAGE, utilizando proteínas fracionadas de tecido muscular de tucunarés oriundo do rio Negro. Os círculos vermelhos indicam possíveis proteínas.

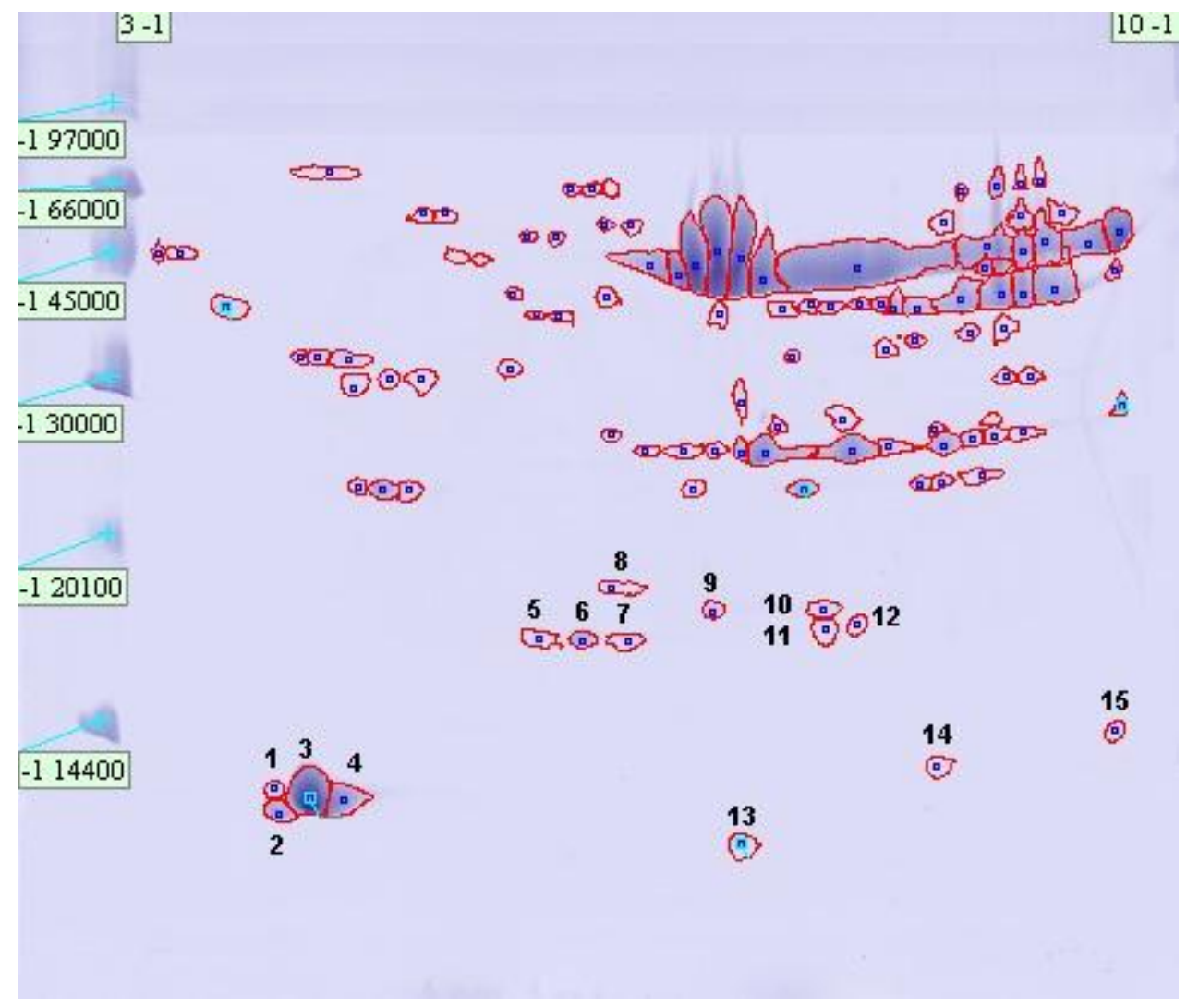

As separações por 2D-PAGE foram feitas em quadriplicata possibilitando as análises de correlação dos géis, bem como obtenção da massa de proteína necessária para quantificação de mercúrio total.

Na etapa de tratamento das imagens, a análise de correlação entre os quatro géis (matching) demonstrou que, em média, 93\% dos spots proteicos estavam presentes em todos os géis, sendo o desvio padrão de apenas $4 \%$. Além disso, foram identificados os spots presentes nos quatro géis, sendo a média de 106 spots. Devido ao grande número de spots foi necessário selecioná-los para posterior quantificação do mercúrio.

As proteínas de menor massa molar são mais favoráveis a ligações com átomos de mercúrio. De acordo com Rodrigues et al. (2008) as metalotioneínas (massa molar $<10 \mathrm{kDa})$ possuem grande quantidade de cisteínas, que são aminoácidos com grupos sulfidrila, os quais forma complexos estáveis com metais como o mercúrio.

Dessa forma, apenas as 15 proteínas identificadas na Figura 13, localizadas no gel abaixo de 20,1 kDa, foram selecionadas para quantificação de mercúrio total por espectrometria de absorção atômica em forno de grafite (GFAAS). 
A Tabela 11 apresenta as concentrações de mercúrio total determinadas nos 15 spots proteicos, bem como seus respectivos pontos isoelétricos, massas molares e massas de proteína, obtidos através do programa ImageMaster 2D Platinum 7.0. Essas proteínas com pontos isoelétricos entre 4,04 e 9,73 e massas molares entre 11,67 e $18,72 \mathrm{kDa}$ são as indicadas para trabalhos futuros de caracterização.

Tabela 11 - Concentração de mercúrio total por GFAAS, pI, massa molar e massa de proteína dos 15 spots proteicos das amostras de tecido muscular de tucunarés coletados no rio Negro.

\begin{tabular}{ccccc}
\hline Spot & $\begin{array}{c}\text { Ponto } \\
\text { isoelétrico }\end{array}$ & $\begin{array}{c}\text { Massa molar } \\
(\mathbf{k D a})\end{array}$ & $\begin{array}{c}\text { Massa de } \\
\text { proteína } \\
(\boldsymbol{\mu g})\end{array}$ & $\begin{array}{c}\text { Concentração de Hg } \\
(\mathbf{n g})\end{array}$ \\
\hline 1 & 4,04 & 13,05 & 0,71 & 2,49 \\
\hline 2 & 4,07 & 12,51 & 4,46 & 2,59 \\
\hline 3 & 4,31 & 13,05 & 23,85 & 1,92 \\
\hline 4 & 4,56 & 12,93 & 7,50 & 1,44 \\
\hline 5 & 5,83 & 17,13 & 0,26 & 1,29 \\
\hline 6 & 6,10 & 17,06 & 2,14 & 2,82 \\
\hline 7 & 6,43 & 17,10 & 0,41 & 3,36 \\
\hline 8 & 6,32 & 18,72 & 0,15 & 1,87 \\
\hline 9 & 7,00 & 17,84 & 0,83 & 2,42 \\
\hline 10 & 7,81 & 17,63 & 0,38 & 2,02 \\
\hline 11 & 7,81 & 17,00 & 0,30 & 1,32 \\
\hline 12 & 7,97 & 17,77 & 0,18 & 1,85 \\
\hline 13 & 7,25 & 11,67 & 0,45 & 2,31 \\
\hline 14 & 8,54 & 13,91 & 0,14 & 1,31 \\
\hline 15 & 9,73 & 13,94 & 0,15 & \\
\hline
\end{tabular}

A concentração média de mercúrio nos 15 spots foi de 2,03 $\pm 0,63 \mathrm{ng}$, sendo o menor teor quantificado nos spots 5 e o maior no spot 7 .

Além dos spots, a quantificação do mercúrio total também foi feita nos precipitados em duas frações $(>50 \mathrm{kDa}$ e $<50 \mathrm{kDa}$ ) e na solução preparada com o precipitado solubilizado, obtido na segunda etapa, que foi aplicada na fita IEF. O objetivo foi fazer um balanço de massa do mercúrio determinado no tecido muscular até o spot proteico, e estimar o quanto foi perdido em cada etapa.

Não foi detectada a presença de mercúrio em precipitados de maior massa molar, resultantes das duas primeiras precipitações. Já os precipitados menores que $50 \mathrm{kDa}$, obtidos na terceira etapa da precipitação fracionada, apresentou a média de 0,145 \pm $0,0049 \mu \mathrm{g} / \mathrm{g}$. 
A concentração média de mercúrio no pellet solubilizado, obtido na terceira precipitação, e posteriormente aplicado na fita de IEF, foi de $0,163 \pm 0,0028 \mu \mathrm{g} / \mathrm{g}$.

Considerando essas duas concentrações, tem-se que $89 \%$ do mercúrio presente no pellet, obtido na terceira precipitação, foi encontrado na massa de proteína solubilizada e aplicada na fita de IEF. Os outros $11 \%$ provavelmente foi perdido no preparo das amostras antes da determinação das concentrações de mercúrio.

Comparando as concentrações médias de mercúrio total no pool dos tecidos musculares dos tucunarés $(1,17 \mathrm{mg} / \mathrm{kg})$ com as concentrações médias dos pellets proteicos de menor massa molar, tem-se apenas $12,4 \%$ do mercúrio do tecido encontrado nos pellets.

A soma das concentrações de mercúrio dos 15 spots proteicos, apresentados na Figura 13 e Tabela 11, foi de 30,397 ng e a soma das massas de proteínas foi de 41,91 . $10^{-6} \mathrm{~g}$. Considerando o mercúrio encontrado nos spots e o determinado na massa de proteína da solução onde o pellet estava solubilizado para aplicação na fita do IEF $(0,163 \mu \mathrm{g} / \mathrm{g})$, pode-se afirmar que $49,74 \%$ do mercúrio no pellet solubilizado estava também presente nos spots proteicos.

Além do balanço de massa, também foram feitos cálculos mais detalhados a fím de estimar a quantidade de átomos de mercúrio presentes por moléculas de proteína. Para tanto, consideraram-se as massas molares dos spots proteicos, a massa molar do mercúrio $\left(200,59 \mathrm{~g} \mathrm{~mol}^{-1}\right)$, a constante de Avogadro $\left(6,022 \cdot 10^{23}\right)$ e que $1 \mathrm{kDa}$ corresponde a $1,661.10^{-24} \mathrm{~g}$ (NEVES et al., 2012).

De acordo com os dados apresentados na Tabela 12 é possível avaliar a existência de uma relação estequiométrica muito pequena entre o número de átomos de mercúrio e o número de moléculas dos spots proteicos. Os maiores valores foram de $1,17.10^{-4}$ no spot 8 e $1,16 \cdot 10^{-4}$ no spot 14 . 
Tabela 12 - Número de átomos de mercúrio por molécula de spot proteico das amostras de tecido muscular de tucunarés (Cichla temensis) coletados no rio Negro.

\begin{tabular}{cccc}
\hline $\begin{array}{c}\text { Spots } \\
\text { proteicos }\end{array}$ & $\begin{array}{c}\text { Moléculas } \\
\text { no spot proteico } \\
\left(\times 10^{14}\right)\end{array}$ & $\begin{array}{c}\text { Átomos } \\
\text { de Hg } \\
\left(\times 10^{11}\right)\end{array}$ & $\begin{array}{c}\text { Átomos de Hg por } \\
\text { moléculas de proteína } \\
\left(\times 10^{-4}\right)\end{array}$ \\
\hline 1 & 0,33 & 7,46 & 0,23 \\
\hline 2 & 2,15 & 7,77 & 0,04 \\
\hline 3 & 11,00 & 5,77 & 0,01 \\
\hline 4 & 3,49 & 4,32 & 0,01 \\
\hline 5 & 0,09 & 3,87 & 0,42 \\
\hline 6 & 0,75 & 8,45 & 0,11 \\
\hline 7 & 0,15 & 10,10 & 0,70 \\
\hline 8 & 0,05 & 5,63 & 1,17 \\
\hline 9 & 0,28 & 7,26 & 0,26 \\
\hline 10 & 0,13 & 4,14 & 0,32 \\
\hline 11 & 0,11 & 6,07 & 0,57 \\
\hline 12 & 0,06 & 3,98 & 0,65 \\
\hline 13 & 0,23 & 5,56 & 0,24 \\
\hline 14 & 0,06 & 6,94 & 1,16 \\
\hline 15 & 0,06 & 3,92 & 0,61 \\
\hline
\end{tabular}

Todos os cálculos deste estudo estão descritos no Anexo 2. 


\section{DISCUSSÕES}

A Correlação de Spearman sugere que as variáveis concentração de mercúrio total e comprimento possuem uma relação direta de proporcionalidade apenas com a classe de águas claras (rios Solimões, Purus e Madeira). De acordo com Kehrig e colaboradores (2008), o comprimento representa a tempo de vida de cada peixe, quanto maior o seu tamanho, maior é tempo vida e, consequentemente, como no ambiente a presença do mercúrio é constante, então maior é o tempo de exposição a esse metal.

Entretanto, a falta de algumas informações como tempo de vida de cada peixe, disponibilidade de alimentos em cada região amostrada e, sobretudo, ao pequeno número de amostras não permitem fazer inferências com mais confiança.

Os resultados deste estudo são semelhantes aos encontrados na literatura. De modo geral, apresentaram pouca variação independente do local de amostragem e em alguns casos as concentrações de mercúrio ultrapassam o limite considerado seguro pela legislação brasileira.

Esses dados são preocupantes do ponto de vista toxicológico, visto que, as populações tradicionais amazônicas consomem em média 16 kg/pessoa/ano ou 44 $\mathrm{g} / \mathrm{pessoa} / \mathrm{dia}$, um dos consumos mais elevados do mundo (BARTHEM \& FABRÉ, 2004).

Neste estudo, os tucunarés do rio Negro apresentaram as maiores concentrações de mercúrio. Sendo o metilmercúrio a maior fração do mercúrio total (mais de 90\%), esta neurotoxina potente possivelmente possui os maiores níveis nos tucunarés amostrados no rio Negro (IKINGURA \& AKAGI, 2003; PASSOS et al., 2007). Já a porcentagem de ribeirinhos que consomem peixes duas vezes ao dia na bacia do rio Negro é de 78,6\%, sendo o consumo per capita de peixe estimado em $200 \mathrm{~g} / \mathrm{dia}$ (BARBOSA et al., 2003).

Apesar de não haver evidências concretas de casos de doenças degenerativas do sistema nervoso central associadas à contaminação de mercúrio no pescado consumido por populações tradicionais no Brasil, as elevadas concentrações de mercúrio aliadas ao grande consumo de pescado exigem a implementação de medidas de prevenção à contaminação como a criação de políticas públicas, monitoramento desse elemento no ambiente e aprimoramento das ferramentas clínicas que permitam a detecção dos seus efeitos (DÓREA, 2003; PASSOS et al., 2003).

A principal medida adotada quando há confirmação de contaminação do pescado por mercúrio é restrição na dieta das comunidades. Essa restrição é eficiente para evitar 
a contaminação humana, mas está longe de ser a melhor forma de resolver o problema, pois os peixes possuem outras substâncias que são essenciais à saúde, como o ômega-3 e os ácidos graxos, os quais são dificilmente encontrados em outras fontes (BARBOSA et al., 2003; MALM, 1998; PASSOS et al., 2003). Outros elementos essenciais para desenvolvimento de funções no organismo humano estão mais disponíveis em peixes do que em outras fontes. Peixes quando comparados ao leite, por exemplo, possuem cinco vezes mais cobre, duas vezes mais cálcio, ferro, manganês e zinco (DÓREA, 2003).

Além de ser necessário mudar as estratégias em casos de contaminação, é preciso que as concentrações máximas de mercúrio permitidas em alimentos sejam amplamente debatidas, sempre levando em consideração que o mercúrio é cumulativo e que alguns efeitos manifestam-se apenas longos períodos após a contaminação.

Os limites determinados no Brasil são muito permissivos, visto que, em outros países o nível seguro, preconizado pela Organização Mundial da Saúde (OMS), não ultrapassa $0,5 \mathrm{mg} / \mathrm{kg}$ para qualquer espécie. Além disso, a legislação brasileira não foi elaborada considerando o consumo de peixes dos países tropicais, que são muito maiores quando comparados a outros países.

Quanto às fontes de mercúrio, as da bacia do rio Negro ainda são muito discutidas na literatura, já que neste rio não há histórico de atividades de mineração de ouro (FADINI \& JARDIM, 2001). Segundo Forsberg (1999) atividades de garimpo próximo a Santa Isabel do Rio Negro ocorreram com cerca de 200 dragas no início de 1993, entretanto, a atividade foi rapidamente reprimida pelas autoridades ambientais.

Dessa forma, o garimpo não justifica as altas concentrações de mercúrio nos tucunarés amostrados neste estudo e em outras espécies estudadas por Barbosa et al. (2003) e Belger \& Forsberg (2006) na bacia do rio Negro. O desmatamento causado pela agricultura extensiva que ocorreu entre os anos 1970 a 1980, além da lixiviação de agrotóxicos e produtos químicos oriundos de indústrias para os mananciais, foram algumas das fontes (BARBOSA et al., 2003; MALM, 1998; , ROULET et al., 1999). Contudo, alguns pesquisadores afirmam que a deposição e incorporação de mercúrio de fontes antrópicas são insignificantes quando comparadas às reservas naturais provenientes da geologia (FADINI \& JARDIM, 2001; ROULET et al., 1998).

Fadini \& Jardim (2001) estimam que depósito natural de mercúrio na camada superior do solo da superfície da bacia do Rio Negro é de 126 mil toneladas e que os podzólicos amazônicos liberam mercúrio mais rapidamente para os corpos hídricos devido à presença de complexos orgânicos. De acordo com Santos et al. (2005) de 
janeiro a julho, a bacia do Rio Negro transborda, inundando cerca de $15000 \mathrm{~km}^{2}$ de floresta e disponibilizando mercúrio para os corpos aquáticos.

Além do nível trófico, o tempo de vida e o tamanho do peixe, alguns parâmetros da água relacionados com a acidez, quantidade de carbono orgânico dissolvido, salinidade, $\mathrm{pH}$ e potencial redox também influenciam nas concentrações de mercúrio em seus tecidos (BARBOSA et al., 2003; MICARONI et al., 2000).

Alguns rios amazônicos como o Negro e seu afluente da margem esquerda, o rio Apuaú, são ricos em ácidos húmicos e fúlvicos que acidificam e escurecem a água. Essa classe de águas possui condutividade de até $8 \mathrm{~S} / \mathrm{cm}$ e têm altas concentrações de sódio e potássio, o que diminui o pH (abaixo de 5,5). Tais condições favorecem a metilação do mercúrio e o aumento da bioacumulação desse elemento nos organismos aquáticos. (BARTHEM \& FABRÉ, 2004; ROCHA et al., 2000).

Ao contrário de rios com águas brancas, como os rios Madeira, Purus e Solimões, os quais nascem na região Pré-Andina e Andina, possuem menores teores de matéria orgânica, mas grande quantidade de material particulado inorgânico, turbidez e condutividade elevadas, $\mathrm{pH}$ próximo ao neutro e são relativamente ricas em cálcio $\left(\mathrm{Ca}^{2+}\right)$ e bicarbonatos $\left(\mathrm{HCO}_{3}{ }^{-}\right)$, o que as classificam como carbonatadas (BARTHEM \& FABRÉ, 2004; QUEIROZ et al., 2009).

Os rios Madeira e Solimões possuem histórico de garimpo, já no rio Purus não há relatos de frequente atividade garimpeira, mas por estar localizado numa região próxima a do rio Negro, espera-se que as concentrações de mercúrio também sejam de origem natural (BASTOS \& LACERDA, 2004; MARTINELLI et al., 1988; PADOVANI et al., 1995).

A distribuição das concentrações de mercúrio em função do local de amostragem é bem heterogênea, entretanto é possível observar que as menores concentrações foram determinadas em tucunarés de reservatórios artificiais. Dentre os reservatórios, o da Usina Hidrelétrica de Tucuruí apresentou os maiores níveis de mercúrio quando comparado aos reservatórios das Usinas Hidrelétricas de Balbina e Cana Brava. Uma possível influência para essas grandes concentrações de mercúrio em Tucuruí é o garimpo de ouro e as reservas naturais desse elemento presentes na geologia da região onde está instalada a usina.

No rio Uatumã não há histórico de mineração de ouro (KASPER et al., 2014). Müller (1994) afirma que antes do enchimento do reservatório da UHE Balbina, a vegetação nativa não foi removida, isto implica em disponibilização de muita matéria 
orgânica a longo prazo, e contribuição na metilação do mercúrio. Além disso, esse rio possui águas escuras, as quais são mais favoráveis à metilação do mercúrio.

De acordo com Mailmen et al. (2006), nos reservatórios hidrelétricos a produção de mercúrio pode durar até 13 anos, variando devido à quantidade de matéria orgânica presente no local. Por se tratar de um metal que pode bioacumular, este pode persistir em peixes de reservatório por até 30 anos após o alagamento, o que afeta toda a cadeia alimentar da região, incluindo a comunidade pescadora. Os reservatórios de criação recente possuem características que favorecem a metilação do mercúrio como anoxia, $\mathrm{pH}$ levemente ácido, matéria orgânica e atividade microbiana intensa (LACERDA \& MALM, 2008).

Schetagne \& Verdon (1999) monitoraram mercúrio em 5 espécies de peixes nos anos de 1978 a 1996 no Complexo Hidrelétrico La Grande, em Quebéc, Canadá. O estudo indicou que as concentrações aumentaram rapidamente logo após o represamento em todas as espécies de peixes e que tendem a retornar aos níveis naturais somente após 10 a 25 anos para espécies não piscívoras e 20 a 30 anos para piscívoras.

As concentrações de mercúrio também aumentam em função do tamanho do reservatório, quanto maior é a área alagada maior é a disponibilização do mercúrio para a água e organismos aquáticos. Dessa forma, apesar da UHE Cana Brava ser mais recente, seu reservatório é menor quando comparado a UHE Tucuruí e UHE Balbina, isso pode justificar as maiores concentrações de mercúrio encontradas nos tucunarés oriundos dessas usinas.

Além disso, as concentrações de mercúrio nos tecidos dos tucunarés capturados na região onde está instalada a UHE Cana Brava pode ter origem do garimpo de ouro, muito praticado na região próxima à usina, e da decomposição da matéria orgânica presente no reservatório (DA SILVA et al., 2006).

O mercúrio persiste na atmosfera por muitos meses, devido à sua alta estabilidade química, elevada pressão de vapor e natureza hidrofóbica (DA SILVA et al., 2006). Além disso, Krabbenhoft \& Sunderland (2013) afirmam que o aumento das emissões de bromo para a atmosfera, além de comprometer a camada de ozônio pode influenciar o tempo de residência do mercúrio na atmosfera em até $66 \%$. Diante disso, o mercúrio pode ser transportado na atmosfera por longas distâncias, afetando áreas remotas naturais longe de suas fontes pontuais de contaminação, isso o classifica como um poluente global (LACERDA \& MALM, 2008). 
Dessa forma, o mercúrio determinado nos tucunarés capturados no reservatório da UHE Cana Brava também pode ser proveniente da região amazônica.

Neste estudo também foi feita a otimização do método de fracionamento de proteínas em gel de poliacrilamida (2D-PAGE) de tucunarés oriundos do rio Negro, além da identificação das proteínas candidatas a biomarcadores de mercúrio.

Não foi encontrada a presença de mercúrio em precipitados acima de $50 \mathrm{kDa}$, obtidos por meio da precipitação fracionada. As proteínas de menor massa molar podem apresentar sequências peptídicas contendo aminoácidos com grupos sulfidrilas ou tióis, os quais possuem características de base mole e formam ligações preferencialmente com ácidos moles, como o mercúrio (GARCIA et al., 2006).

A porcentagem de mercúrio encontrado nos pellets de menor massa molar, originários do tecido muscular dos tucunarés do rio Negro, foi de apenas $12,4 \%$, sendo que nesses pellets foram também perdidos $11 \%$ de mercúrio quando solubilizados para aplicação na fita de IEF.

Apenas 49,74\% do mercúrio determinado nos pellets de menor massa molar solubilizados estava também presente nos spots proteicos. Isso justifica a baixa relação estequiométrica encontrada entre o número de átomos de mercúrio e o número de moléculas dos spots proteicos.

Possivelmente, a maior parte desse mercúrio está ligado a outros compostos e/ou macromoléculas, como lipídeos e carboidratos, e outra parte pode ter sido perdida durante o processo de mineralização das amostras para determinação das concentrações de mercúrio total.

Além disso, esse percentual indica que os procedimentos de preparo das amostras, como a precipitação fracionada em três etapas, foi eficiente para ser aplicado na 2D-PAGE, pois preservou a estrutura metal-proteína.

Barghigiani et al. (1989) e Passos et al. (2007) afirmam que na musculatura de peixes mais de $90 \%$ do mercúrio total está na forma de metilmercúrio. Além disso, essa espécie de mercúrio é lipossolúvel, isto é, associa-se facilmente aos lipídeos.

A proteína denominada metalotioneína é rica em cisteína que é capaz de se ligar a alguns metais pesados, tais como $\mathrm{Cd}, \mathrm{Zn}, \mathrm{Cu}$ e $\mathrm{Hg}$. Além disso, o dimetilmercúrio tem baixa afinidade com as metalotioneínas, ao contrário do mercúrio inorgânico e do metilmercúrio que se encontram comumente associados a esse tipo de proteína (BARGHIGIANI et al., 1989). 
Isso sugere que, possivelmente, a maior parte do mercúrio total determinado nos spots proteicos, que inicialmente estava presente no tecido muscular, está na forma de inorgânica. Como essa espécie de mercúrio associa-se facilmente às metalotioneínas e proteínas metal-binding, acredita-se que essas proteínas estejam presentes nos spots proteicos apresentados neste estudo. Entretanto, seria necessária a determinação de cada forma de mercúrio (orgânico e inorgânico) para fazer inferências com mais confiança.

Os resultados indicam a presença de átomos de mercúrio em 15 spots proteicos de pontos isoelétricos entre 4,04 e 9,73 e massas molares entre 11,67 e 18,72 kDa. Analisando a relação de átomos de mercúrio por moléculas de proteínas, apesar de pequena, pode-se indicar 2 possíveis proteínas, identificadas no gel como spots 8 e 14, com maior relação estequiométrica. Essas proteínas podem ser as mais promissoras a biomarcadores de mercúrio em tucunarés.

Dessa forma, a 2D-PAGE mostrou-se eficiente na investigação de metaloproteínas associadas ao mercúrio em amostras de tecido muscular de tucunarés. Além disso, a correlação média das repetições dos géis possibilitou a massa necessária de proteínas para detecção do mercúrio.

Esses dados poderão auxiliar trabalhos futuros de identificação e caracterização dessas proteínas, as quais são candidatas a biomarcadores da toxicidade do mercúrio, para posteriormente, serem criadas ferramentas de prevenção à contaminação por mercúrio em comunidades tradicionais que vivem diretamente da pesca. 


\section{CONCLUSÕES}

As concentrações de mercúrio no tecido muscular dos tucunarés, de modo geral, são semelhantes às documentadas na literatura em vários lugares do mundo, sobretudo na região amazônica. Contudo, essas concentrações são discrepantes dos limites máximos definidos na legislação.

Esses dados alertam para uma detalhada revisão das concentrações de mercúrio total consideradas seguras para os seres humanos, visto que a legislação brasileira não considera um consumo tão elevado de peixes como ocorre em populações amazônicas.

A 2D-PAGE mostrou-se eficiente na investigação de metaloproteínas associadas ao mercúrio em amostras de tecido muscular de Tucunarés Açu (Cichla temensis) naturais do rio Negro. Além disso, a boa correlação média das repetições dos géis possibilitou a massa necessária de proteínas para detecção do mercúrio.

Por meio das imagens dos géis e da quantificação do mercúrio nos precipitados pode-se concluir que o mercúrio está associado às proteínas de menor massa molar $(<20,1 \mathrm{kDa})$. Foram identificadas 15 proteínas candidatas a biomarcadores da toxicidade do mercúrio em tucunarés, sendo 2 consideradas mais promissoras.

Quanto ao balanço de massa de mercúrio, 12,4\% do mercúrio determinado na musculatura dos tucunarés estava presente nos pellets proteicos com massas molares abaixo de $50 \mathrm{kDa}$. Sendo que 49,74 \% do mercúrio presente nos precipitados de menor massa molar solubilizados também foi encontrado nos spots proteicos.

Dessa forma, a precipitação fracionada em três etapas foi um método eficiente para ser aplicado no método de fracionamento de proteínas em gel de poliacrilamida (2D-PAGE), indicando que os procedimentos de extração das proteínas foram adequados, os quais preservaram a estrutura metal-proteína. Além disso, é provável que o mercúrio encontrado esteja na forma inorgânica, visto que, a maior parte do mercúrio presente nos tecidos é o metilmercúrio, o qual é lipossolúvel.

Esses resultados metalômicos são importantes no subsidio de trabalhos futuros de caracterização de biomarcadores de mercúrio em peixes. Tanto as concentrações de mercúrio quanto a identificação de proteínas associadas ao mercúrio apresentadas neste estudo, alertam para investimentos em pesquisas a longo prazo, objetivando a criação de políticas públicas e de programas de monitoramento continuado nos vários compartimentos ambientais, além do aprimoramento de ferramentas de segurança alimentar frente à uma contaminação por mercúrio. 


\section{REFERÊNCIAS}

AMORIM, L. C. A. Os biomarcadores e sua aplicação na avaliação da exposição aos agentes químicos ambientais. Revista Brasileira de Epidemiologia, v. 6, n. 1, 2003.

AMORIM, M.I.M.; MERGLER, D.; BAHIA, M.O.; DUBEAU, H.; MIRANDA, D.C.; LEBEL, J; BURBANO, RR; LUCOTTE, M. Cytogenetic Damage Related to Low Levels of Methyl Mercury Contamination in the Brazilian Amazon. Anais da Academia Brasileira de Ciências, Rio de Janeiro, v. 72, n. 4, p. 497-507, dez. 2000.

ANJOS, H. D. B.; ZUANON, J.; BRAGA, T. M. P.; SOUSA, K. L. S. Fish, upper Purus River, state of Acre, Brazil. Check List, v. 4, n. 2, p. 198-213, 2008.

AYRES, J.M. As matas de várzea do Mamirauá. MCT-CNPq- Programa do Trópico Úmido- Brasília - DF. Sociedade Civil Mamirauá. 123 pp, 1995.

BARNES, D. B.; PIERCE, G. F.; LICHTI, D.; LANDT, M.; KOENIG, J.; CHAN, K. M. Effects of dextran on five biuret-based procedures for total protein in serum.

Clinical Chemistry, v. 31, p. 2018-2019, 1985.

BARBOSA, A. C.; DE SOUZA, J.; DÓREA, J. G.; JARDIM, W. F.; FADINI, P. S. Mercury biomagnification in a tropical black water, Rio Negro, Brazil. Environmental Contamination Toxicology, v. 45, n. 2, p. 235-246, ago. 2003.

BARGHIGIANI, C.; PELLEGRINI, D.; CARPENE, E. Mercury binding proteins in liver and muscle of flat fish from the northern Tyrrhenian Sea.

Comparative Biochemistry and Physiology, v. 94, n.1, p. 309-312, abr. 1989.

BARTHEM, R. B.; FABRÉ, N. N. Biologia e diversidade dos recursos pesqueiros da Amazônia. In: RUFFINO, M. L. (Coord.). A pesca e os recursos pesqueiros na Amazônia brasileira. Manaus: Ibama/ProVárzea, 272 p., 2004.

BASTOS, W. R. Ocorrência ambiental do mercúrio e sua presença em populações ribeirinhas do Baixo rio Madeira - Amazônia. Tese (doutorado), Universidade Federal do Rio de Janeiro, Rio de Janeiro, 111 p., 2004.

BASTOS, W. R.; ALMEIDA, R.; DÓREA, J. G.; BARBOSA, A. C. Annual flooding and fish-mercury bioaccumulation in the environmentally impacted Rio Madeira (Amazon). Ecotoxicology, v.16, n. 3, p. 341-346, abr. 2007. 
BASTOS, W. R.; GOMES, J. P. O.; ALMEIDA, R.; OLIVERIA, R. C.; NASCIMENTO, E. L.; BERNARDI, J. V. E.; LACERDA, L. D.; SILVEIRA, E. G.; PFEIFFER, W. C. Mercury in the environment and riverside population in the Madeira River basin, Amazon, Brazil. Science of the Total Environment, v. 368, n. 1, p. 344351, set. 2006.

BASTOS, W. R.; LACERDA, L. D. A contaminação por mercúrio na bacia do rio Madeira: uma breve revisão. Geochimica Brasiliensis, v.18, n. 2, p. 99-114, jul. 2004.

BELGER, L.; FORSBERG, B. R. Factors controlling Hg levels in two predatory fish species in the Negro river basin, Brazilian Amazon. Science of the Total

Environment, v. 367, n. 1, p. 451-459, ago. 2006.

BERKLMAN, T.; STENSTEDT, T. 2-D electrophoresis using immobilized pH gradients: principles and methods. Uppsala: Amersham Biosciences, 1998.

BOISCHIO, A. A. P.; BARBOSA, A. Exposure to organic mercury in riparian populations on the upper Madeira River, Rondonia, Brazil, 1991: preliminary results. Caderno de Saúde Pública, Rio de Janeiro, v. 9, n. 2, p. 155-160, abr./jun. 1993.

BOISCHIO, A. A.; HENSHEL, D. Fish consumption, fish lore, and mercury pollution risk communication for the Madeira River people. Environmental Research, v. 84, n. 2, p. 108-126, out. 2000.

BORRELL, A.; AGUILAR, A.; TORNERO, V.; DRAGO, M. Concentrations of mercury in tissues of striped dolphins suggest decline of pollution in Mediterranean open waters. Chemosphere, v. 107, p. 319-323, jul. 2014.

BRACHT, A.; ISHII-IEAMOTO, E. L. Métodos de laboratório em bioquímica. Manole: Barueri, São Paulo. 2003.

BRAGA, C.P.; BITTARELLO, A.C.; PADILHA, C.C.F.; LEITE, A.L.; MORAES, P.M.; BUZALAF, M.A.R.; ZARA, L.F.; PADILHA, P.M. . Mercury fractionation in dourada (Brachyplatystoma rousseauxii) of the Madeira River in Brazil using metalloproteomic strategies. Talanta. v. 132, p. 239-244, 2014.

BRASIL. Ministério da Saúde. Agência Nacional de Vigilância Sanitária. Resolução RDC $n^{\circ}$ 42. Diário Oficial da República Federativa do Brasil, Brasília, DF, 29 de agosto de 2013. 
CANAVAN, C.M.; CALDWELLB, C.A.; BLOOMC, N.S. Discharge of methylmercury-enriched hypolimnetic water from a stratified reservoir. Science of the Total Environment, v. 260, n. 1-3, p. 159-170, out. 2000.

CARVALHO, D. C.; OLIVEIRA, D. A. A.; SANTOS, J. E.; TESKE, P.; BEHEREGARAY, L. B.; SCHNEIDER, H.; SAMPAIO, I. Genetic characterization of native and introduced populations of the neotropical cichlid genus Cichla in Brazil. Genetics and Molecular Biology, São Paulo, v. 32, n. 3, p. 601-607, jul. 2009.

CASTILHOS, Z. C.; BIDONE, E. D. Hg biomagnification in the ichthyofauna of the Tapajo's River Region, Amazonia, Brazil. Environmental Contamination Toxicology, v. 64, n. 5, p. 693-700, mai. 2000.

CASTILHOS, Z. C.; BIDONE, E. D.; HARTZ, S. M. Bioaccumulation of mercury by Tucunare (Cichla ocellaris) from Tapajos River region, Brazilian Amazon: A field dose-response approach. Environmental Contamination Toxicology, v. 66, n. 5, p. 631-637, mai. 2001.

CORREA, L.; REA, L. D.; BENTZEN, R.; O'HARA, T. M. Assessment of mercury and selenium tissular concentrations and total mercury body burden in 6 Steller sea lion pups from the Aleutian Islands. Marine Pollution Bulletin, v. 82, n. 1, p. 175-182, mai. 2014.

CORTECCI, G. Geologia e saúde. Bologna: Università degli Studi di BolognaDipartimento di Scienze della Terra e Geologico-Ambientale. Trad. de Wilson Scarpelli, p. 05-17, 2003.

COX-FERNANDES, C. Diversity, distribution and community structure of electric fishes in the Amazon Basin. Tese (doutorado), Duke University, Durham, 394 p, 1995.

DA SILVA, G. S.; JARDIM, W. F.; FADINI, P. S. Elemental gaseous mercury flux at the water/air interface over the Negro River basin, Amazon, Brazil. Science of the total environment, v. 368, n. 1, p. 189-198, set. 2006.

DIETZ, R.; SONNE, C.; BASU, N.; BRAUNE, O'HARA, T.; LETCHER, R. J.; SCHEUHAMMER, T.; ANDERSEN, M.; ANDREASEN, C.; ANDRIASHEK, D.; ASMUND, G.; AUBAIL, A.; BAAGØE, H.; BORN, E. W.; CHAN, H. M.; DEROCHER, A. E.; GRANDJEAN, P.; KNOTT, K.; KIRKEGAARD, M.; KREY, A.; LUNN, N.; MESSIER, F.; OBBARD, M.; OLSEN, M. T.; OSTERTAG, S.; PEACOCK, E.; RENZONI, A.; RIGÉT, F. F.; SKAARE, J. U.; STERN, G.; 
STIRLING, I.; TAYLOR, M.; WIIG, O.; WILSON, S.; AARS, J. What are the toxicological effects of mercury in Arctic biota? Science of the Total Environment, $v$. 443, n. 15, p. 775-790, jan. 2013.

DÓREA, J.G. Fish are central in the diet of Amazonian riparians: should we worry about their mercury concentrations? Environmental Research, v.92, n. 3, p. 232-244, jul. 2003.

DÓREA, J. G.; BARBOSA, A. C. Anthropogenic impact of mercury accumulation in fish from the rio Madeira and rio Negro rivers (Amazonia). Biological Trace Element Research, v. 115, n. 3, p. 243-254, 2007.

ENERGIA SUSTENTÁVEL DO BRASIL. 2013. Disponível em:

<http://www.energiasustentaveldobrasil.com.br/a-usina>. Acesso em: 03 de março de 2015 .

FABRÉ, N. N.; DONATO, J. C.; ALONSO, J. C. Bagres de la Amazonia Colombiana: Um Recurso sin Fronteiras. Instituto Amazónico de Investigaciones Científicas. Bogotá. 253 p, 2000.

FADINI, P. S.; JARDIM, W. F. Is the Negro River Basin (Amazon) impacted by naturally occurring mercury? Science of the Total Environment, v. 275, n. 1-3, p. 7182, jul. 2001.

FORSBERG, M. C. S.; FORSBERG, B. R.; ZEIDEMANN, V. K. Mercury Contamination in Humans Linked to River Chemistry in the Amazon Basin. Ambio, v. 28, n. 6, p. 519-521, set. 1999.

FRANZINELLI, E. Características morfológicas da confluência dos rios Negro e Solimões (Amazonas, Brasil). Revista Brasileira de Geociências, v. 41, n. 4, p. 587596, 2011.

FURNAS, ODEBRECHT, LEME ENGENHARIA. Relatório de Impacto Ambiental dos Aproveitamentos Hidrelétricos Santo Antônio e Jirau, Madeira-RO - RIMA: manual de orientação. 82 p., mai. 2005.

GANTHER, H. E.; SUNDE, M. L. Factors in fish modifying methylmercury toxicity and metabolism. Biological Trace Element Research, v. 119, p. 221-233, set. 2007. 
GARCIA, J. S.; MAGALHÃES, C. S.; ARRUDA, M. A. Z. Trends in metal-binding and metalloprotein analysis. Talanta. v. 69, p. 1-15, 2006.

GE HEALTHCARE. Manual do usuário. ImageMaster 2D Platinum 7.0 Edition AA, 2007.

GRIESBAUER, L. Methylmercury contamination in fish and shellfish. CSA Discovery Guides. 9 p. fev. 2007.

GROTTO, D.; VALENTINI, J.; FILLION, M.; PASSOS, C. J. S.; GARCIA, S. C.; MERGLER, D.; BARBOSA JÚNIOR, F. Mercury exposure and oxidative stress in communities of the Brazilian Amazon. Science of the Total Environment, v. 408, n. 4, p. 806-811, jan. 2010.

GUIMARÃES, P. R. B. Métodos Quantitativos Estatísticos. Curitiba: IESDE Brasil S.A. 245 p, 2008.

GUIMARÃES, S. T.; LIMA, H. N.; TEIXEIRA, W. G.; NEVES JUNIOR, A. F.; SILVA, F. W. R.; MACEDO, R. S.; SOUZA, K. W. Caracterização e classificação de gleissolos da várzea do Rio Solimões (Manacapuru e Iranduba), Amazonas, Brasil.

Revista Brasileira de Ciências do Solo, v. 37, p. 317-326, 2013.

HONDA, S.; HYLANDER, L.; SAKAMOTO, M. Recent Advances in Evaluation of Health Effects on Mercury with Special Reference to Methylmercury - A Minireview. Environmental Health and Preventive Medicine, v. 11, n. 4, p. 171-176, Jul. 2006.

IBAMA. Plano de manejo da estação ecológica de Anavilhanas. 1999. Disponível em:

<http://www.icmbio.gov.br/parnaanavilhanas/images/stories/plano_de_manejo/Plano_d e_Manejo_Anavilhanas_ps.pdf >. Acesso em: 12 de fevereiro de 2015.

IBAMA. Avaliação das questões sociais decorrentes da instalação da UHE Cana Brava. Parecer no. 69/2012. Disponível em:

$<$ http://licenciamento.ibama.gov.br/Hidreletricas/Cana\%20Brava/Parecer\%20T\%E9cnic o_\%20Passivos\%20Ambientais_UHE\%20Cana\%20Brava.pdf >. Acesso em: $27 \mathrm{de}$ outubro de 2014.

IKINGURA, J.R.; AKAGI, H. Total mercury and methylmercury in fish from hydroeletric reservoirs in Tanzânia. Science of the Total Environment, v. 304, n. 1-3, p. 355-368, mar. 2003. 
JACOB-FERREIRA, A.L. B.; LACCHINI, R.; GERLACH, R. F.; PASSOS, C. J. S.; BARBOSA JÚNIOR, F.; SANTOS, J. E. T. A common matrix metalloproteinase (MMP)-2 polymorphism affects plasma MMP-2 levels in subjects environmentally exposed to mercury. Science of the Total Environment, v. 409, v. 20, p. 4242-4246, set. 2011.

JAHANBAKHT, S., LIVARDJANI, F. \& JAEGER, A. An experimental ecotoxicological study and its application to the behavioural study of organic mercury $(\mathrm{CH} 3 \mathrm{HgCl})$ in the environment: influence of temperature and $\mathrm{pH}$. Chemosphere, v. 49 , n. 10, p. 1399-1405, dez. 2002.

JUNK, W.J. As águas da região Amazônica. In: SALATI, E.; JUNK, W.J.; SCHUBART, H.O.R. (eds.). Amazônia: Desenvolvimento, Integração e Ecologia, p. 45-100, 1983.

KASPER, D.; FORSBERG, B. R.; AMARAL, J. H. F.; LEITÃO, R. P.; PY-DANIEL, S. S.; BASTOS, W. R.; MALM, O. Reservoir Stratification Affects Methylmercury Levels in River Water, Plankton, and Fish Downstream from Balbina Hydroelectric Dam, Amazonas, Brazil. Environmental Science Technology, v. 48, n. 2, p. 10321040, jan. 2014.

KASPER, D.; PALERMO, E. F. A.; BRANCO, C. W. C.; MALM, O. Evidence of elevated mercury levels in carnivorous and omnivorous fishes downstream from an Amazon reservoir. Hydrobiologia, v. 694, n. 1, p. 87-98, set. 2012.

KEHRIG H. A.; HOWARD, B. M.; MALM, O. Methylmercury in a predatory fish (Cichla spp.) inhabiting the Brazilian Amazon. Environmental Pollution, v. 154, n. 1, p. 68-76, jul. 2008.

KEHRIG, H. A.; MALM, O.; AKAGI, H.; GUIMARÃES, J. R. D.; TORRES, J. P. M. Methylmercury in Fish and Hair Samples from the Balbina Reservoir, Brazilian Amazon. Environmental Research, v. 77, n. 2, p. 84-90, mai. 1998.

KEHRIG, H. A.; PALERMO E. F. A.; SEIXAS, T. G.; SANTOS, H. S. B.; MALM, O.; AKAGI, H. Methyl and total mercury found in two man-made Amazonian Reservoirs. Journal of the Brazilian Chemical Society, São Paulo, v. 20, n. 6, p. 1142-1152, 2009.

KRABBENHOFT, D. P.; SUNDERLAND, E. M. Global change and mercury. Science, v. 341, p. 1457-1458, set. 2013. 
KULLANDER, S. O.; FERREIRA, E. J. G. A review of the South American cichlid genus Cichla, with descriptions of nine new species (Teleostei: Cichlidae).

Ichthyological Exploration of Freshwaters, v. 17, n. 4, p. 289-398, 2006.

LA MONTE, F. R. Fishes from rio Juruá and rio Purus, Brazilian Amazonas. American Museum Novitates, n. 784, p. 1-8, 1935.

LACERDA, L. D. Amazon Mercury Emissions. Nature, v. 374, p. 20-21, 1995.

LACERDA, L.D. Global mercury emissions from gold and silver mining. Water, Air and Soil Pollution, v. 97, n. 3-4, p. 209-221, 1997.

LACERDA, L. D.; MALM, O. Contaminação por mercúrio em ecossistemas aquáticos: uma análise das áreas críticas. Estudos avançados, v. 22, n. 63, 2008.

LAMA, S. N. D.; ROCHA, C. D.; JARDIM, W. F.; TSAI, J-S.; CRAWFORD, P. F. Sedentary nestlings of Wood Stork as monitors of mercury contamination in the gold mining region of the Brazilian Pantanal. Environmental research, v. 111, n. 8, p. 1091-1095, nov. 2011.

LEHNINGER, A., L.; NELSON, D., L.; COX, M., M. Lehninger princípios de bioquímica. ARTMED, $5^{\text {a }}$ ed., 1273 p., 2011.

LEMIRE, M.; FILLION, M.; FRENETTE, B.; PASSOS, C. J. S.; GUIMARÃES, J. R. D.; BARBOSA JÚNIOR, F.; MERGLER, D. Selenium from dietary sources and motor functions in the Brazilian Amazon. NeuroToxicology, v. 32, n. 6, p. 944-953, dez. 2011.

LIMA, P. M.; NEVES, R. C. F.; SANTOS, F. A.; PÉREZ, C. A.; SILVA, M. A. O.; ARRUDA, M. A. Z.; CASTRO, G. R.; PADILHA, P. M. Analytical approach to the metallomic of Nile tilapia (Oreochromis niloticus) liver tissue by SR-XRF and FAAS after 2D-PAGE separation: Preliminary results. Talanta, v. 82, p. 1052-1056, 2010.

MAILMAN, M.; STEPNUK, L.; CICEK, N.; BODALY, R.A. Strategis to lower methyl mercury concentrations in hydroelectric reservoirs and lakes: A review. Science of the Total Environment, v. 368, n. 1, p. 224-235, set. 2006.

MALM, O. Gold mining as a source of mercury exposure in the Brazilian Amazon. Environmental Research, v. 77, n. 2, p. 73-78, mai. 1998. 
MALM, O.; BRANCHES, F. J. P.; AKAGI, H.; CASTRO, M. B.; PFEIFFER, W. C.; HARADA, M.; BASTOS, W. R.; KATO, H. Mercury and methylmercury in fish and human hair from the Tapajos river basin, Brazil. Science of the Total Environment, v. 175, n. 2, p.141-150, dez. 1995a.

MALM, O.; CASTRO, M. B.; BASTOS, W. R.; BRANCHES, F. J. P.; GUIMARÃES, J. R. D.; ZUFFO, C. E.; PFEIFFER, W. C. An assessment of Hg pollution in different goldmining areas, Amazon Brazil. Science of the Total Environment, v. 175, n. 2, p. 127-140, dez. 1995b.

MALM, O. ; GUIMARÃES, J.R.D. ; CASTRO, M.B. ; BASTOS, W.R. ; VIANA, J.P. ; SILVEIRA, E.G.; PFEIFFER, W.C. Follow-up of mercury levels in fish, human hair and urine in the Madeira and Tapajós basins, Amazon, Brazil. Water, Air and Soil Pollution, v. 97, n. 1-2, p. 45-51, jun. 1997.

MARTINELLI, L. A.; FERREIRA, J. R.; FORSBERG, B. R.; VICTORIA, R. L. Mercury contamination in the Amazon: A gold rush consequence. Ambio, v. 17, n. 4, p. 252-254, 1988.

MICARONI, R. C. C. M.; BUENO, M. I. M. S.; JARDIM, W. F. Compostos de mercúrio. Revisão de métodos de determinação, tratamento e descarte. Química Nova, v. 23, n.4, p. 487-495, fev. 2000.

MIRANDA, J. C.; MAZZONI, R. Estrutura e persistência temporal da comunidade de peixes de três riachos do Alto Rio Tocantins, GO. Biota Neotropica, v. 9, n. 4, p. 7178, out./dez. 2009.

MOARES, C. S.; OLIVEIRA JÚNIOR, F. O. R.; MASSON, G.; REBELLO, K. M.; SANTOS, L. O.; BASTOS, N. F. P.; FARIA, R. C. R. Métodos experimentais no estudo de proteínas. Rio de Janeiro: IOC, 84 p.,

2013a.

MORAES, PAULA M.; SANTOS, FELIPE A.; CAVECCI, BRUNA; PADILHA, CILENE C.F.; VIEIRA, JOSÉ C.S.; ROLDAN, PAULO S.; PADILHA, PEDRO DE M. GFAAS determination of mercury in muscle samples of fish from Amazon, Brazil. Food Chemistry. v. 141, p. 2614-2617, 2013 b.

MÜLLER, I. N. J. Infra-estruturas de apoio a grandes empreendimentos e as alterações no meio ambiente. Dissertação (mestrado). Universidade de São Paulo, São Paulo, dez. 1994. 
NEVES, R. C. F.; LIMA, P. M.; BALDASSINI, W. A.; SANTOS, F. A.; MORAES, P. M.; CASTRO, G. R.; PADILHA P. M. Fracionamento de cobre em proteínas do plasma, músculo e fígado de Tilápia do Nilo. Química Nova, v. 35, p. 493-498, 2012.

ORGANIZAÇÃO MUNDIAL DE SAÚDE (OMS). Elementos traço na nutrição e saúde humana. São Paulo: Roca, 1998.

PADOVANI, C. R.; FORSBERG, B. R.; PIMENTEL, T. P. Contaminação mercurial em peixe do rio Madeira: resultados e recomendações para consumo humano. Acta Amazônica, v. 20, n. 1/2, p. 127-136, 1995.

PASSOS, C. J.; MERGLER, D.; GASPAR, E.; MORAIS, S.; LUCOTTE, M.;

LARRIBE, F.; DAVIDSON, R.; GROSBOIS, S. Eating tropical fruit reduces mercury exposure from fish consumption in the Brazilian Amazon. Environmental Research, v. 93, n. 2, p. 123-130, out. 2003.

PASSOS, C. J. S.; MERGLER, D.; LEMIRE, M.; FILLION, M.; GUIMARÃES, J. R. D. Fish consumption and bioindicators of inorganic mercury exposure. Science of the Total Environment, v. 373, n. 1, p. 68-76, fev. 2007.

PELÁEZ-RODRIGUEZ, M.; PERET, A. M.; MATSUMURA-TUNDISI, T.; ROCHA, O. Análise da qualidade da água e aplicação do Índice de Proteção da Vida Aquática (IVA) em duas sub-bacias da bacia hidrográfica do Jacaré-Guaçu. In: ESPÍNDOLA, E. L. G.; PASCHOAL, C. R. B.; ROCHA, O.; BOHER, M. B. C.; NETO, A. L. O.

Ecotoxicologia - Perspectivas para o Século XXI, Rima Editora, 2000.

PESCARIA ESPORTIVA. 2010. Disponível em:

<http://www.abunapescaesportiva.com.br/tucunare>. Acesso em: 03 de março de 2015.

PORVARI, P. Mercury levels of fish in Tucurui hydroelectric reservoir and in River Mojti in Amazonia, in the state of Par\& Brazil. Science of the Total Environment, v. 175, p.109-117, 1995.

QUEIROZ, A. R. S.; MOTTA-VEIGA, M. Análise dos impactos sociais e à saúde de grandes empreendimentos hidrelétricos: lições para uma gestão energética sustentável. Ciência e saúde coletiva, v.17, n. 6, p. 1387-1398, jun. 2012.

QUEIROZ, M. M. A.; HÖRBE, A. M. C.; SEYLER, P.; MOURA, C. A. V. Hidroquímica do rio Solimões na região entre Manacapuru e Alvarães - Amazonas Brasil. Acta Amazonica. v. 39, n. 4, p. 943-952, 2009. 
REIS, V. L.; MALDONADO, M. R.; AMARAL, E. F.; CAVALCANTE, A. P. B. M. Caracterização socioambiental das bacias hidrográficas do Estado do Acre. Ministério Público do Estado do Acre, 376 p., 2009. Disponível em:

<http://www.mp.ac.gov.br/wp-content/files/Imagem03.pdf >. Acesso em: 10 de outubro de 2014.

RIBEIRO, C. A. O.; NATHALIE, M. D.; GONZALEZ, P.; YANNICK, D.; JEANPAUL, B.; BOUDOU, A.; MASSABUAU, J. C. Effects of dietary methylmercury on zebrafish skeletal muscle fibres. Environmental Toxicology and Pharmacology, v. 25, p. 304-309, 2008.

ROCHA, A.A. Produtos de pesca e contaminantes químicos na água da Represa Billings, São Paulo (Brasil). Revista de Saúde Pública, São Paulo, v. 9, n. 5, p. 401-10, 1985.

ROCHA, J. C.; SARGENTINI JÚNIOR, É.; ZARA, L. F.; ROSA, A. H.; DOS SANTOS, A.; BURBA, P. Redução de mercúrio (II) pelas substâncias húmicas tropicais rio (Rio Negro) - Um possível processo do ciclo do mercúrio no Brasil. Talanta, v. 53, n. 3, p. 551-559, dez. 2000.

RODRÍGUEZ ÁLVAREZ, C.; JIMÉNEZ MORENO, M.; GUZMÁN BERNARDO, F. J.; RODRÍGUEZ MARTÍN-DOIMEADIOS, R. C.; BERZAS NEVADO, J. J. Mercury methylation, uptake and bioaccumulation by the earthworm Lumbricus terrestris (Oligochaeta). Applied Soil Ecology, v. 84, p. 45-53, 2014.

RODRIGUES, J. L.; BATISTA, B. L.; NUNES, J. A.; PASSOS, C. J. S.; BARBOSA JÚNIOR, F. Evaluation of the use of human hair for biomonitoring the deficiency of essential and exposure to toxic elements. Science of the Total Environment, v. 405, n. 1-3, p. 370-376, dez. 2008.

ROSENBERG, D. M.; RESH, V. H. (eds.). Freshwater biomonitoring and benthic macroinvertebrates. New York, Chapman \& Hall, 488 p., 1993.

ROULET, M.; LUCOTTE, M.; FARELLA, N.; SERIQUE, G.; COELHO, H.; PASSOS, C. J. S.; JESUS DA SILVA, E.; ANDRADE, P. S.; MERGLER, D.; GUIMARÃES, J.-R. D.; AMORIM, M. Effects of recent human colonization on the presence of mercury in Amazonian Ecosystems. Water, Air, and Soil Pollution. v. 112, n. 3-4, p. 297-313, jun. 1999.

ROULET, M.; LUCOTTE, M.; SAINT-AUBIN, A.; TRAN, S.; RHEAULT, I.; FARELLA, N.; DE JESUS DA SILVA, E.; DEZENCOURT, J.; PASSOS, C. J. S.; 
SOARES, G. S.; GUIMARÃES, J. R. D.; MERGLER, D. AMORIM, M. The geochemistry of mercury in central Amazonian soils developed on the Alter-do-Chao formation of the lower Tapajos River Valley, Para state, Brazil. Science of the Total Environment, v. 223, n. 1, p. 1-24, 1998.

RUELAS-INZUNZA, J.; ESCOBAR-SÁNCHEZ, O.; PATRÓN-GÓMEZ, J.; MORENO-SÁNCHEZ, X. G.; MURILLO-OLMEDA, A.; SPANOPOULOSHERNÁNDEZ, M.; CORRO-ESPINOSA, D. Mercury in muscle and liver of ten ray species from Northwest Mexico. Marine Pollution Bulletin, v. 77, n. 1-2, p. 434-436, dez. 2013.

SANCHES, F.; FISCH, G. As possíveis alterações microclimáticas devido a formação do lago artificial da hidrelétrica de Tucuruí -PA. Acta Amazonica, v. 35, n. 1, p. 41-50, 2005.

SANTANA, A. C.; BENTES, E. S.; HOMMA, A. K. O.; OLIVEIRA, F. A.; OLIVEIRA, C. M. Influência da barragem de Tucuruí no desempenho da pesca artesanal, estado do Pará. Revista de Economia e Sociologia Rural, v. 52, n. 2, p. 249266, jun. 2014.

SANTOS, F. A.; LIMA, P. M.; NEVES, R. C. F.; MORAES, P. M.; PÉREZ, C. A.; SILVA, M. A. O.; ARRUDA, M. A. Z.; CASTRO, G. R.; PADILHA P. M. Metallomic study of plasma samples from Nile tilapia using SR-XRF and GFAAS after separation by 2D PAGE: Initial results. Microchimica Acta, v. 173, p. 43-49, 2011.

SANTOS, E. O.; SÁ, G. C.; JESUS, I. M.; BRABO, E. S.; CÂMARA, V. M.; LIMA, M. O.; FAIAL, K. F.; MENDES, R. A.; MASCARENHAS, A. F. S. Mercúrio no rio Negro, Amazonas, Brasil - Estudo preliminar de indicadores de exposição no pescado e em populações humanas. Cadernos Saúde Coletiva, v. 13, n. 1, p. 225 -236, 2005.

SCHETAGNE, R.; VERDON, R. Post-Impoundment Evolution of Fish Mercury Levels at the La Grande Complex, Québec, Canada (from 1978 to 1996). In: Mercury in the Biogeochemical Cycle. Springer Berlin Heidelberg, p. 235-258, 1999.

SILVA, F. A.; CAVECCI, B.; BALDASSINI, W. A.; LIMA, P. M.; MORAES, P. M.; ROLDAN, P. S.; PADILHA, C. C. F.; PADILHA P. M. Selenium fractionation from plasma, muscle and liver of Nile tilapia (Oreochromis niloticus). Journal of Food Measurement and Characterization, v. 7, p. 158-165, 2013. 
SILVA, C. C.; FERREIRA, E. J. G.; DEUS, C. P. Dieta de cinco espécies de Hemiodontidae (Teleostei, Characiformes) na área de influência do reservatório de Balbina, rio Uatumã, Amazonas, Brasil. Iheringia Série Zoologia, v. 98, n. 4, p. 465468, dez. 2008.

SILVA, G S.; FILIPAK NETO, F.; ASSIS, H. C. S.; BASTOS, W. R.; RIBEIRO, C. A. $O$. Potential risks of natural mercury levels to wild predator fish in an Amazon reservoir. Environmental Monitoring and Assessment. v. 184, n. 8, p. 4815-4827, ago. 2012

SILVA, L. A.; SCARIOT, A. Composição florística e estrutura da comunidade arbórea em uma floresta estacional decidual em afloramento calcário (Fazenda São José, São Domingos, GO, bacia do rio Paranã). Acta Botanica Brasilica, v. 17, n. 2, p. 305-313, abr./jun. 2003.

SIOLI, H. Hydrochemistry and geology in the Brazilian Amazon region. Amazoniana. v. 1, p. 74-83, 1984.

SOUZA, J. R., BARBOSA. A. C. Contaminação por mercúrio e o Caso da Amazônia. Química e Sociedade. v. 12, p. 3-7, 2000.

STATSOFT. Inc. STATISTICA. (data analysis software system). Version 7.1. www.statsoft.com. 2005.

STEIGER, A. Compreender a história da vida: do átomo ao pensamento humano. São Paulo: Paulus. 271 p., 1998.

SYKES, E.; GRZYCH, C.; EPSTEIN, E.; KIECHLE, F. L. Dextran interference in biuret-based assays for serum proteins. Clinical Chemistry, v. 33, p. 1073, 1987.

TAYLOR, C.M.; GOLDING, J.; EMOND, A. M. Girl or boy? Prenatal lead, cadmium and mercury exposure and the secondary sex ratio in the ALSPAC study. Reproductive Toxicology, v. 46, p. 137-140, jul. 2014.

TUOMOLA, L.; NIKLASSON, T.; SILVA, E. C.; HYLANDER, L. D. Fish mercury development in relation to abiotic characteristics and carbon sources in a six-year-old, Brazilian reservoir. Science of the Total Environment. v. 390, n. 1, p. 177-187, fev. 2008. 
URYU, Y.; MALM, O.; THORNTON, I.; PAYNE, I.; CLEARY, D. Mercury contamination of fish and its implications for other wildlife of the Tapajos Basin, Brazilian Amazon. Conservation Biology. v. 15, n. 2, p. 438-446, abr. 2001.

VIEIRA, S. M.; DE ALMEIDA, R.; HOLANDA, I. B. B.; MUSSY, M. H.; GALVÃO, R. C. F.; CRISPIM, P. T. B.; DÓREA, J. G.; BASTOS, W. R. Total and methylmercury in hair and milk of mothers living in the city of Porto Velho and in villages along the Rio Madeira, Amazon, Brazil. International Journal of Hygiene and Environmental Health, v. 216, n. 6, p. 682-689, nov. 2013.

VOGIATZIS, C. G.; ZACHARIADIS, G. A. Tandem mass spectrometry in metallomics and the involving role of ICP-MS detection: A review. Analytica Chimica Acta, v. 819, p. 1-14, 2014.

VROOM, F. Q.; GREER, M. Mercury vapour intoxication. Brain. v. 95, n. 2, p. 305318, p. 1972.

WAGNER, M. B. Significância com confiança? Jornal de Pediatria. v. 74, p. 343-346, 1998.

WARREN, C. E. Biology and water pollution control. Saunders Company, Philadelphia, 434 p., 1971.

WILLIAMS, R. J. P. Chemical selection of elements by cells. Coord. Chem. Rev., v. 583, p. 216-217, 2001.

WILLIS, S. C.; NUNES, M. S.; MONTAÑA, C. G.; FARIAS, I. P.; LOVEJOY, N. R. Systematics, biogeography, and evolution of the Neotropical peacock basses Cichla (Perciformes: Cichlidae). Molecular Phylogenetics and Evolution, v. 44, n. 1, p. 291307, jul. 2007. 


\section{APÊNDICE}

APÊNDICE A - Cálculos

\section{Exemplo de cálculo para concentração de mercúrio no Spot Proteico 1}

Dados do Spot 1

Massa de proteína: $0,71 \cdot 10^{-6} \mathrm{~g}$

Concentração de mercúrio: 0,4970 ng/L (média)

*O fator de diluição das amostras foi de $5 \mathrm{~mL}$, o qual foi inserido no cálculo para os 15 spots de acordo com o exemplo abaixo:

$$
\begin{aligned}
& 0,4970 \mathrm{ng} \rightarrow 1000 \mathrm{~mL} \\
& \mathrm{x} \quad \rightarrow 5 \mathrm{~mL} \\
& \mathbf{x}=\mathbf{0 , 0 0 2 4 8} \mathbf{~ n g}
\end{aligned}
$$

Após encontrar a concentração de mercúrio real dos spots (com fator de diluição incluído), dividiu-se a concentração do mercúrio pela massa de proteínas:

$$
\begin{gathered}
\mathrm{C}_{\mathrm{Hg}}=0,00248 \mathrm{ng} / 0,71 \cdot 10^{-6} \mathrm{~g} \\
\mathrm{C}_{\mathrm{Hg}}=2,48 \cdot 10^{-6} \mathrm{mg} / 0,71 \cdot 10^{-6} \mathrm{~g} \\
\mathrm{C}_{\mathrm{Hg}}=0,0035 \mathrm{mg} / \mathrm{g}
\end{gathered}
$$

\section{Exemplo de cálculo estequiométrico para o Spot Proteico 1}

Dados do Spot 1

Massa molar $=13,052 \mathrm{kDa}$ ou $13052 \mathrm{Da}$

Massa de proteína $=0,71 \cdot 10^{-6} \mathrm{~g}$

Mercúrio do spot $1=0,0035 \mathrm{mg} / \mathrm{g}$

Massa molar do mercúrio $=200,59 \mathrm{~g} / \mathrm{mol}$

$\mathrm{N}^{\circ}$ Avogadro $=6,02 \cdot 10^{23}$

$1 \mathrm{Da}=1,661 \cdot 10^{-24} \mathrm{~g}$

$1^{\circ}$ - Calculou-se o número de moléculas de proteínas no spot.

$$
\begin{gathered}
1 \mathrm{Da} \rightarrow 1,661.10^{-24} \mathrm{~g} \\
13052 \mathrm{Da} \rightarrow \mathrm{x} \\
\mathrm{x}=2,17 \cdot 10^{-20} \mathrm{~g}
\end{gathered}
$$


$2,17.10^{-20} \mathrm{~g} \rightarrow 1$ molécula de proteína

$0,71 \cdot 10^{-6} \mathrm{~g} \rightarrow \mathrm{x}$

$\mathrm{x}=3,27 \cdot 10^{13}$ moléculas de proteína

$2^{\circ}$ - Calculou-se o número de átomos de mercúrio.

$$
\begin{gathered}
0,0035 \mathrm{mg} \rightarrow 1 \mathrm{~g} \text { de proteína } \\
\mathrm{x} \rightarrow 0,71 \cdot 10^{-6} \mathrm{~g} \\
\mathrm{x}=0,00248 \cdot 10^{-6} \mathrm{mg} \text { de } \mathrm{Hg} \text { ou } 2,48 \cdot 10^{-12} \mathrm{~g} \text { de } \mathrm{Hg} \\
200,59 \mathrm{~g}(\mathrm{MM} \mathrm{Hg}) \rightarrow 6,02 \cdot 10^{23} \text { átomos de } \mathrm{Hg} \\
2,48 \cdot 10^{-12} \mathrm{~g} \rightarrow \mathrm{x} \\
\mathrm{x}=0,075 \cdot 10^{11} \text { ou } 7,5 \cdot 10^{9} \text { átomos de mercúrio }
\end{gathered}
$$

$3^{\circ}$ - Calculou-se a relação de átomos de mercúrio por moléculas de proteína.

$$
\begin{aligned}
& \mathrm{x}=\underline{7,5 \cdot 10^{9}} \\
& 3,27 \cdot 10^{13} \\
& \mathrm{x}=\mathbf{0 , 2 3} . \mathbf{1 0}^{-4} \text { ou } \mathbf{0 , 0 0 0 0 2 3}
\end{aligned}
$$

\section{Cálculo do balanço de massa}

0,163 $\mu \mathrm{g}$ (concentração média Hg na solução aplicada na fita IEF)

$0,145 \mu \mathrm{g}$ (concentração média de $\mathrm{Hg}$ nos pellets proteicos de massa molar $<50 \mathrm{kDa}$ )

$1,17 \mu \mathrm{g}$ (concentração média $\mathrm{Hg}$ no pool de tecidos musculares)

$\checkmark$ Porcentagem de mercúrio comparando-se as concentrações de $\mathrm{Hg}$ dos pellets proteicos de massa molar < 50kDa com o $\mathrm{Hg}$ na solução aplicada na fita IEF:

$0,163 \mu \mathrm{g}$ (concentração média $\mathrm{Hg}$ na solução) $\rightarrow 100 \%$

$0,145 \mu \mathrm{g}$ (concentração média de $\mathrm{Hg}$ nos pellets proteicos) $\rightarrow \mathrm{x}$

$$
\mathrm{x}=89 \% \text { de } \mathrm{Hg}
$$


$\checkmark$ Porcentagem de mercúrio comparando-se as concentrações de $\mathrm{Hg}$ nos pellets proteicos com o $\mathrm{Hg}$ determinado no tecido muscular:

$$
\begin{gathered}
\text { 1,17 } \mu \mathrm{g} \text { (concentração média } \mathrm{Hg} \text { no tecido muscular) } \rightarrow 100 \% \\
0,145 \mu \mathrm{g} \text { (concentração média de } \mathrm{Hg} \text { nos pellets proteicos) } \rightarrow \mathrm{x} \\
\mathbf{x}=\mathbf{1 2 , 4 0 \%} \mathbf{~ d e ~} \mathbf{H g}
\end{gathered}
$$

Concentração de mercúrio na massa total de proteínas considerando os 15 spots proteicos:

$\Sigma$ massas proteína nos spots $=41,91 \mu \mathrm{g}$ ou $41,91.10^{-6} \mathrm{~g}$

$\Sigma$ massas $\mathrm{Hg}$ nos spots $=0,0304 \mathrm{ng}$

$$
\begin{gathered}
\mathrm{C}_{\mathrm{Hg}}=0,0304 \mathrm{ng} / 375 \cdot 10^{-6} \mathrm{~g} \\
\mathrm{C}_{\mathrm{Hg}}=81,07 \mathrm{ng} / \mathrm{g} \text { ou } 0,08107 \mu \mathrm{g} / \mathrm{g}
\end{gathered}
$$

Considerando que a concentração de mercúrio na massa de proteínas da solução aplicada na fita IEF foi de $0,163 \mu \mathrm{g} / \mathrm{g}$ foi feita a seguinte relação:

$$
\begin{gathered}
0,163 \mu \mathrm{g} \rightarrow 100 \% \\
0,08107 \mu \mathrm{g} \rightarrow \mathrm{x} \\
\mathbf{x}=\mathbf{4 9 , 7 4} \% \text { de } \mathbf{H g}
\end{gathered}
$$


ANEXO

ANEXO A - Autorização para atividades com finalidade científica

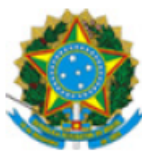

Ministério do Meio Ambiente - MMA

Instituto Chico Mendes de Conservação da Biodiversidade - ICMBio

Sistema de Autorização e Informação em Biodiversidade - SISBIO

\section{Autorização para atividades com finalidade científica}

\begin{tabular}{c|c|c|} 
Número: $40791-2$ & Data da Emissäo: 07/08/2014 16:44 & Data para Revalidação*: 06/09/2015 \\
\hline
\end{tabular}
* De acordo com o art. 33 da IN 154/2009, esta autorização tem prazo de validade equivalente ao previsto no cronograma de atividades do projeto,
mas deverá ser revalidada anualmente mediante a apresentação do relatório de atividades a ser enviado por meio do Sisbio no prazo de até 30 dias
a contar da data do aniversário de sua emissão.

a contar da data do aniversário de sua emissão.

Dados do titular

\begin{tabular}{|l|l|l|l|l|l|l|}
\hline Nome: Wilyane Silva Figueiredo & CPF: 023.632.711-90
\end{tabular}

Título do Projeto: Identificação de biomarcadores de toxicidade do mercúrio em tucunarés na bacia do rio Negro, Tapajós, Madeira e Teles Pires

\begin{tabular}{|l|l|l}
\hline Nome da Instituição : FUNDAÇÃO UNIVERSIDADE DE BRASILIAA & CNPJ: 00.038.174/0001-43 \\
\hline
\end{tabular}

\begin{tabular}{|c|c|c|c|}
\hline \multicolumn{4}{|c|}{ Cronograma de atividades } \\
\hline \# & Descrição da atividade & Início (més/ano) & Fim (més/ano) \\
\hline 1 & Desenho amostral e definiçấo das estaçōes de coleta & $08 / 2013$ & $08 / 2013$ \\
\hline 2 & Levantamento bibliográfico & $09 / 2013$ & $09 / 2014$ \\
\hline 3 & Finalizaçâo da redação da dissertaçâo & $09 / 2013$ & $11 / 2014$ \\
\hline 4 & Amostragem de Tucunarés & $09 / 2013$ & $09 / 2013$ \\
\hline 5 & Tratamento (moagem e liofilização) das amostras de tecido muscular e hepático & $09 / 2013$ & $09 / 2013$ \\
\hline 6 & Determinaçẩo do teor de mercúrio total e de macro e microminerais nas amostras extratos de tecidos & $09 / 2013$ & $09 / 2013$ \\
\hline 7 & Otimizaçäo de métodos para precipitação fracionada de proteínas para obtençâo dos pellets proteicos & $09 / 2013$ & $09 / 2013$ \\
\hline 8 & Determinação de proteína total nos extratos dos pellets proteicos & $09 / 2013$ & $09 / 2013$ \\
\hline 9 & Otimizaçâo de métodos eletroforéticos para fracionamentos das proteinas nas amostras de tecido muscu & $09 / 2013$ & $09 / 2013$ \\
\hline 10 & Amostragem de Tucunarés & $05 / 2014$ & $05 / 2014$ \\
\hline 11 & Tratamento (moagem e liofilizaçẫo) das amostras de tecido muscular e hepático & $05 / 2014$ & $05 / 2014$ \\
\hline 12 & Determinaçảo do teor de mercúrio total e de macro e microminerais nas amostras extratos de tecidos & $05 / 2014$ & $05 / 2014$ \\
\hline 13 & Otimizaçäo de métodos para precipitação fracionada de proteínas para obtençâo dos pellets proteicos & $05 / 2014$ & $05 / 2014$ \\
\hline 14 & Determinação de proteína total nos extratos dos pellets proteicos & $05 / 2014$ & $05 / 2014$ \\
\hline 15 & Otimizaçấo de métodos eletroforéticos para fracionamentos das proteínas nas amostras de tecidos & $05 / 2014$ & $05 / 2014$ \\
\hline 16 & Cálculo da relaçấo do noátomos de $\mathrm{Hg} /$ no de moléculas de protéína dos spots proteicos dos géis obtido & $05 / 2014$ & $05 / 2014$ \\
\hline 17 & Análise dos spots nos quais foram detectados/quantificados presença de mercúrio & $05 / 2014$ & $06 / 2014$ \\
\hline
\end{tabular}

Observações e ressalvas

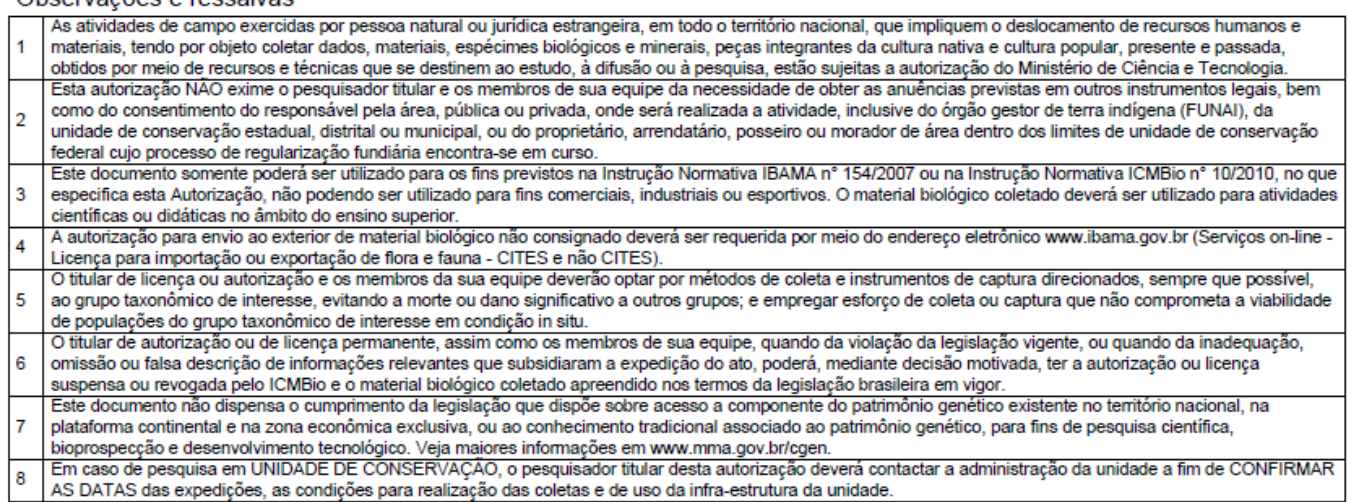

Equipe

Este documento (Autorização para atividades com finalidade cientifica) foi expedido com base na Instrução Normativa $n^{\circ} 154 / 2007$. Através do código de autenticação abaixo, qualquer cidadão poderá verificar a autenticidade ou regularidade deste documento, por meio da página do Sisbio/lCMBio na Internet (www.icmbio.gov.br/sisbio)

Código de autenticação: 19331968

Página 1/3 
Ministério do Meio Ambiente - MMA

Instituto Chico Mendes de Conservação da Biodiversidade - ICMBio

Sistema de Autorização e Informação em Biodiversidade - SISBIO

\section{Autorizaçäo para atividades com finalidade científica}

\begin{tabular}{|c|c|c|}
\hline Número: $40791-2$ & Data da Emissão: 07/08/2014 16:44 & Data para Revalidaçäo*: 06/09/2015 \\
\hline $\begin{array}{l}\text { * De acordo com o art. } 33 \text { da IN 154/2009, esta autorização tem prazo de validade equivalente ao previsto no cronograma de atividades do projeto, } \\
\text { mas deverá ser revalidada anualmente mediante a apresentação do relatório de atividades a ser enviado por meio do Sisbio no prazo de até } 30 \text { dias } \\
\text { a contar da data do aniversário de sua emissão. }\end{array}$
\end{tabular}

a contar da data do aniversário de sua emissão.

Dados do titular

\begin{tabular}{|l|l|l|l|l|l|}
\hline Nome: Wilyane Silva Figueiredo & CPF: 023.632.711-90
\end{tabular}

Título do Projeto: Identificação de biomarcadores de toxicidade do mercúrio em tucunarés na bacia do rio Negro, Tapajós, Madeira e Teles Pires

\begin{tabular}{|l|l}
\hline Nome da Instituição : FUNDAÇÃO UNIVERSIDADE DE BRASÍLIA & CNPJ: 00.038.174/0001-43
\end{tabular}

\begin{tabular}{|c|l|l|l|l|l|}
\hline \multirow{2}{|c|}{ Nome } & \multicolumn{1}{c|}{ Funçäo } & CPF & Doc. Identidade & Nacionalidade \\
\hline 1 & ADEMIR DOS SANTOS & Pesquisador & $034.625 .128-11$ & 93462657 SSPSP-SP & Brasileira \\
\hline 2 & Carlos José Sousa Passos & Pesquisador & $437.358 .192-49$ & 2461794 SSP-PA & Brasileira \\
\hline 3 & Luis Fabricio Zara & Coordenador & $145.513 .058-39$ & 20219582 SSP-SP & Brasileira \\
\hline 4 & Wilson de Figueiredo Jardim & Pesquisador & $871.335 .638-00$ & 6105213 sSp-SP & Brasileira \\
\hline 5 & Tania Machado da Silva & Pesquisador & $046.412 .455-76$ & 5213490 SSP-GO & Brasiera \\
\hline 6 & Julio Cesar Rocha & Pesquisador & $744.372 .838-72$ & 79522324 SSP-SP & Brasileira \\
\hline
\end{tabular}

Locais onde as atividades de campo serão executadas

\begin{tabular}{|c|c|c|l|l|}
\hline$\#$ & Municipio & UF & Descriçäo do local & Tipo \\
\hline 1 & AM & rio Negro & Fora de UC Federal \\
\hline 2 & & RO & rio Madeira & Fora de UC Federal \\
\hline 3 & & PA & rio Tapajós & Fora de UC Federal \\
\hline 4 & MT & Teles Pires & Fora de UC Federal \\
\hline
\end{tabular}

Atividades $X$ Táxons

\begin{tabular}{|l|l|l|}
\hline \multicolumn{1}{|c|}{ Atividade } & \multicolumn{1}{c|}{ Táxons } \\
\hline 1 & Coleta/transporte de amostras biológicas in situ & Cichla \\
\hline 2 & Coleta/transporte de espécimes da fauna silvestre in situ & Cichla (*otde: 20) \\
\hline
\end{tabular}

* Quantidade de individuos por espécie, por localidade ou unidade de conservação, a serem coletados durante um ano.

Material e métodos

\begin{tabular}{|l|l|l|}
\hline 1 & Amostras biológicas (Peixes) & Fragmento de tecido/órgäo \\
\hline 2 & Método de captura/coleta (Peixes) & $\begin{array}{l}\text { Anzol e linha (op.manual):linha de mão,de corso,carretilha,molinete, corrico,vara e isca viva, Captura } \\
\text { manual }\end{array}$ \\
\hline
\end{tabular}

Destino do material biológico coletado

\begin{tabular}{|c|l|c|}
\hline$\#$ & \multicolumn{1}{|c|}{ Nome local destino } & \multicolumn{1}{|c|}{ Tipo Destino } \\
\hline 1 & FUNDACCAO UNIVERSIDADE DE BRASILIA & \\
\hline 2 & UNESP-Faculdade de Ciências e Letras & \\
\hline
\end{tabular}

Este documento (Autorização para atividades com finalidade científica) foi expedido com base na Instrução Normativa n¹54/2007. Através do código de autenticação abaixo, qualquer cidadão poderá verificar a autenticidade ou regularidade deste documento, por meio da página do Sisbio/lCMBio na Internet (www.icmbio.gov.br/sisbio).

Código de autenticação: 19331968 
Ministério do Meio Ambiente - MMA

Instituto Chico Mendes de Conservação da Biodiversidade - ICMBio

Sistema de Autorização e Informação em Biodiversidade - SISBIO

\section{Autorização para atividades com finalidade científica}

\begin{tabular}{|c|c|c|}
\hline \multicolumn{1}{|c|}{ Número: 40791-2 } & Data da Emissäo: 07/08/2014 16:44 & Data para Revalidaçäo*: 06/09/2015 \\
\hline * De acordo com o art. 33 da IN 154/2009, esta autorização tem prazo de validade equivalente ao previsto no cronograma de atividades do projeto, \\
mas deverá ser revalidada anualmente mediante a apresentação do relatório de atividades a ser enviado por meio do Sisbio no prazo de até 30 dias \\
massar
\end{tabular}
a contar da data do aniversário de sua emissão.

Dados do titular

\begin{tabular}{|l|l|}
\hline Nome: Wilyane Silva Figueiredo & \multicolumn{1}{l|}{ CPF: 023.632.711-90 } \\
\hline Título do Projeto: Identificação de biomarcadores de toxicidade do mercúrio em tucunarés na bacia do rio Negro, Tapajós, Madeira e Teles Pires \\
\hline Nome da Instituição : FUNDAÇÃO UNIVERSIDADE DE BRASíLIA & CNPJ: 00.038.174/0001-43 \\
\hline
\end{tabular}

\section{Registro de coleta imprevista de material biológico}

De acordo com a Instrução Normativa $n^{0} 154 / 2007$, a coleta imprevista de material biológico ou de substrato não contemplado na autorização ou na licença permanente deverá ser anotada na mesma, em campo específico, por ocasião da coleta, devendo esta coleta imprevista ser comunicada por meio do relatório de atividades. O transporte do material biológico ou do substrato deverá ser acompanhado da autorização ou da licença permanente com a devida anotação. O material biológico coletado de forma imprevista, deverá ser destinado à instituição científica e, depositado, preferencialmente, em coleção biológica científica registrada no Cadastro Nacional de Coleções Biológicas (CCBIO).

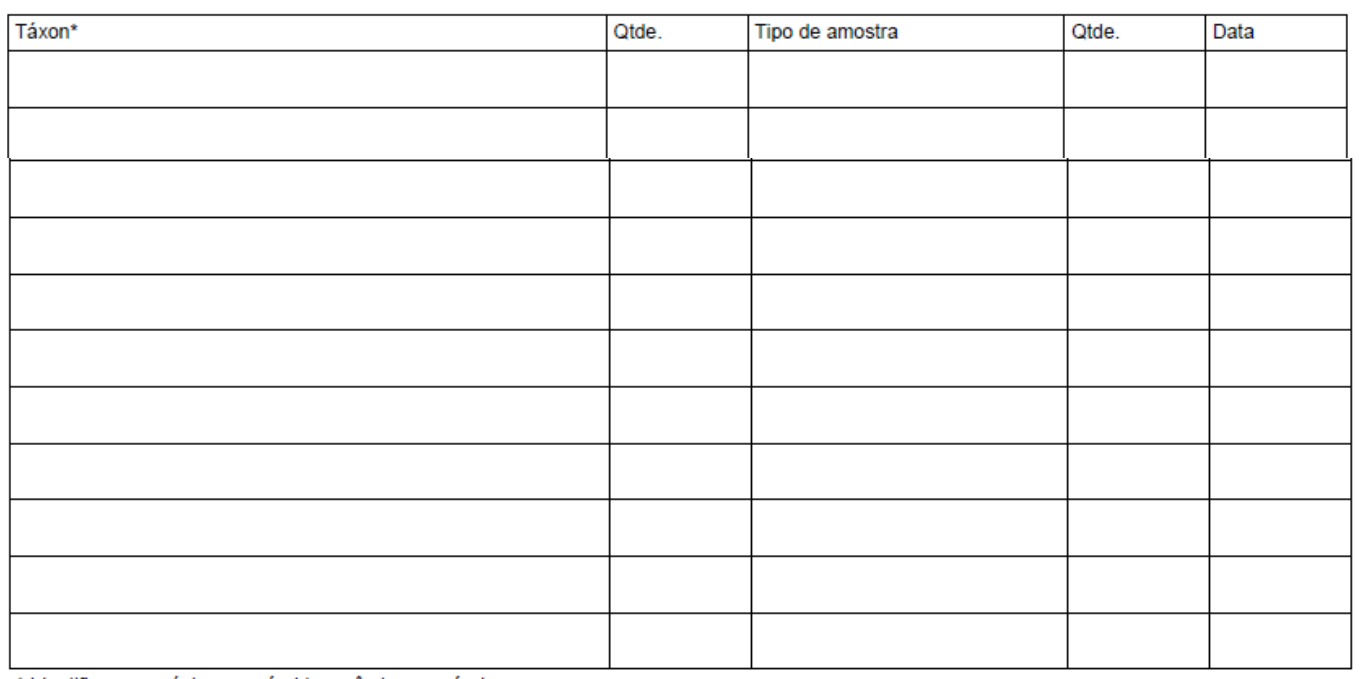

* Identificar o espécime no nível taxonômico possível.

Este documento (Autorização para atividades com finalidade científica) foi expedido com base na Instrução Normativa n¹54/2007. Através do código de autenticação abaixo, qualquer cidadão poderá verificar a autenticidade ou regularidade deste documento, por meio da página do Sisbio/ICMBio na Internet (www.icmbio.gov.br/sisbio)

Código de autenticação: 19331968 